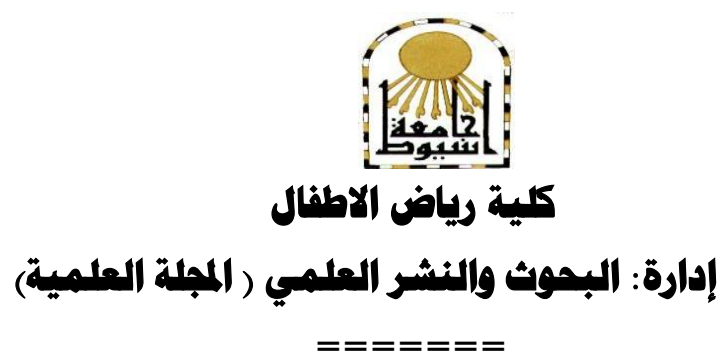

\title{
فاعلية برنامج تدريبى لمعلمات رياض الأطفال فى تنمية بعض مهارات تصميم وإنتاج الثصص الإلكترونية التعليمية المقدمة لطفل الروضة
}

\author{
إعــــداد
}

د/ منال مممود عبد المميد هودى

مدرس بقسم العلوم التريوية

بكلية رياض الأطفال -جامعة أسيوط

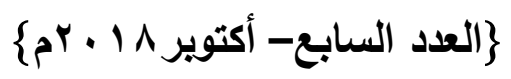




\section{مستخلص البحث}

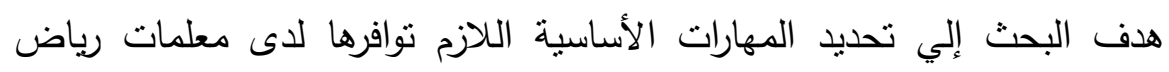

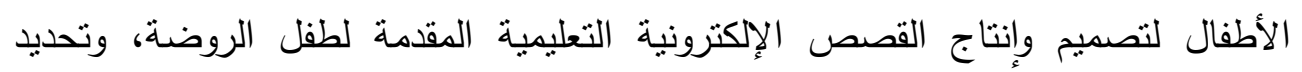
المعايير التربوية والفنية والتقنية التى يتم فى ضوئها تصميم وإنتاج القصص الإلكترونية التعليمية المقدمة لطفل الروضة،هوتصميم برنامج تدريبى لمعلمات رياض ولئية الأطفال لتتمية

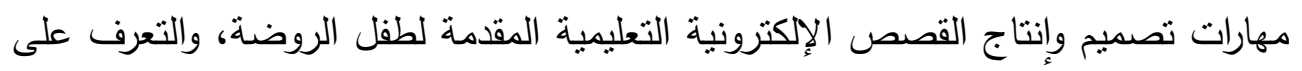
فاعلية البرنامج التدريبى المقترح، وأجري البحث على مجموعة من معلمات رياض الاضثيه الاطفال

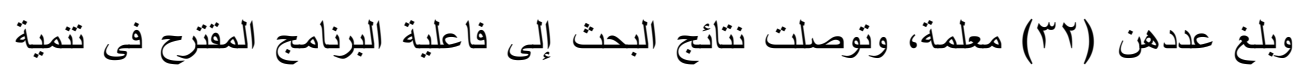
مهارات معلمات رياض الأطفال فى تصميم وإنتاج القصص الإلكترونية التعليمية المقدمة التونة لطفل الروضة، كما نوصلت نتائج البحث الى وجود فروق ذات الصئ دلاتلة إحصائية بين

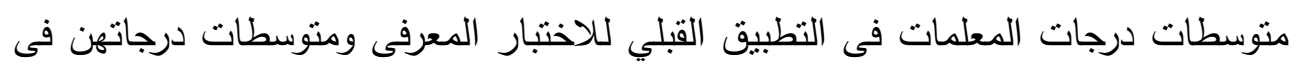
التطبيق البعدى لصالح التطبيق البعدى، ووجود فروق ذات دلالة إحصائية بين منوسطات درجات المعلمات (عينة البحث) فى النطبيق القبلي لبطاقة ملاحظة مهارات تصميم وإنتاج القصص الإككترونية ومتوسطات درجاتهن فى التطبيق البعدى لصالح التطبيق البعدى. الكلمات المفتاحية: القصص الإككترنية - تدريب معلمات رياض الأطفال - مهارات تصميم وإنتاج القصص الإلكترونية - طفل الروضة. 


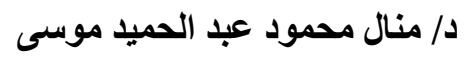

فاعلية برنامج تدريبى لمعلمات رياض الأطفال

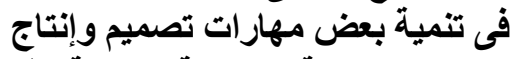

القصص الأكترونية التعليمية المقدمة لطفل الروضة

\title{
Effectiveness of A Training Program for The Kindergarten Teachers in The Development of Some Design and Production Skills Educational Electronic Stories Provided to Kindergarten Children
}

\begin{abstract}
This research aimed at identify the basic skills required by kindergarten teachers to design and produce educational e-stories for the preschool child, and to determine the educational, technical and technical standards in the light of which to design and produce educational e-stories for kindergarten children and to design a training program for kindergarten teachers to develop design skills And the production of electronic educational stories provided to kindergarten children, and to identify the effectiveness of the proposed training program, and conducted a research on a group of kindergarten teachers and the number of 32 teachers, and the results of the research to the effectiveness of the program The results of the study showed that there were statistically significant differences between the mean scores of the teachers in the tribal application of the cognitive test and their mean scores in the remote application for the benefit of the remote application, and the existence of significant differences Statistics between the average scores of the parameters (the research sample) in the pre application of the note card, the skills of designing and producing the electronic stories and their average degrees in the remote application in favor of the remote application.
\end{abstract}

Keywords: Digital stories - training of kindergarten teachers - skills of designing and producing Digital stories- kindergarten Child. 


\section{مقدمة:}

يشهر العصر الحالي تقدماً ملموساً في تكنولوجيا المعلومات،وقد أنعكس ذلك على

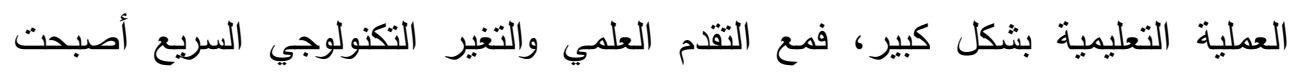
المجتمعات الإنسانية بحاجة إلى تطوير التعليم وإعادة النظر بشكل متكامل في منظومته كونه الهدف الأول لتحقيق التقدم الذي تطمح إليه هذه الثهاته المجتمعات.

كما فرضت التطورات العلمية والتكنولوجية واقعًا جديدًا لم تألفه الساحة التربوية من قبل وأخذت تكنولوجيا التعليم باستخدام الحاسوب دوراً محوريًا في قضايا التعليم بمراحله

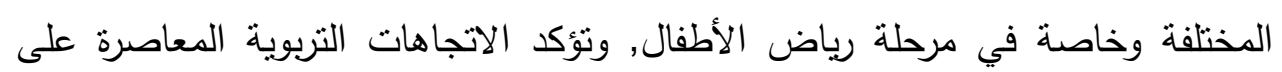

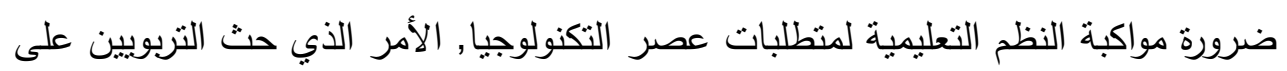

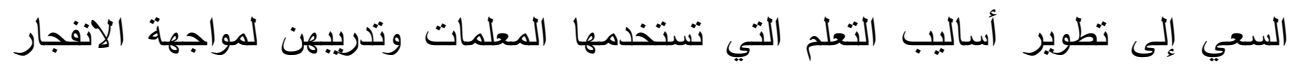

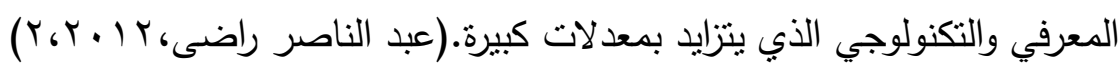
ويعد تدريب معلمات رياض الأطفال ذو أهمية بالغة باعتباره السبيل الوحيد للنمو

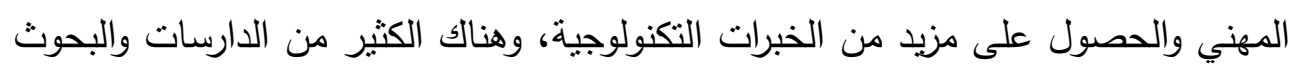
التي أثنارت إلى الحاجة المستمرة لمعلمة الروضة إلى التطوير وفقاً للمستجدات التربوية والتحديات التكنولوجية المعاصرة في مجال نربية الطفل، وأكدت على ضرورة الاهتمام بتدريب معلمات رياض الأطفال على استخدام وتصميم وتتفيذ بعض الأنشطة التكنولوجية فئ فئ

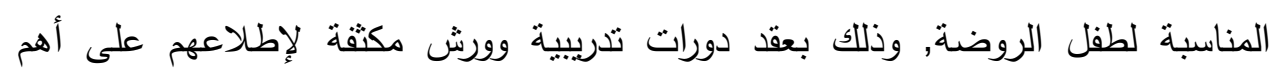

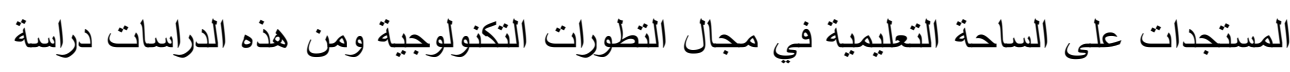

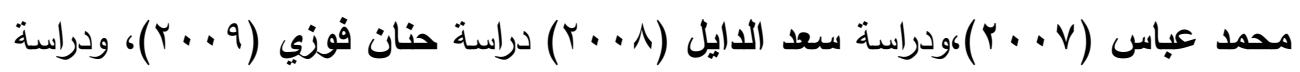

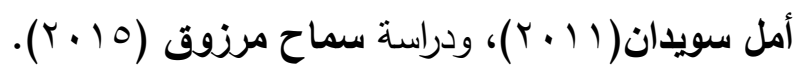
وأصبح الأمر في ظل التطورات التكنولوجية يتطلب الاهتمام بإعداد وتدريب معلمات رياض الأطفال وتطوير أساليب التذريس التي تستخدمها بإدخال المفاهيم التكنولوجية والتعلم الإلكتروني ضمن مناهج رياض الأطفال وتتظيم دورات وبرامج تأهيلية وتطويرية وتكنولوجية تهدف لتأهيل معلمات رياض الأطفال تكنولوجيًا والتوجه نحو 
استراتيجيات وآفاق تربوية وتعليمية وتكنولوجية تتلاءم مع تطورات العصر , وتحدياته

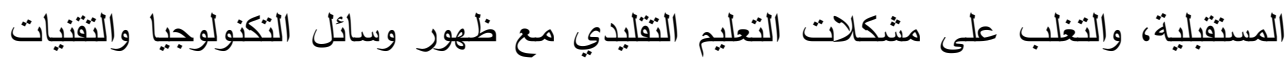
التعليمية الحديثة في التعليم ومنها التعلم الإلكتروني، والألعاب الإككترونية، والنمذجة الإلكترونية، والمحاكاة الإلكترونية والقصص الإككترونية.

وتعد القصص الإلكترونية أحد تطبيقات التعلم الإلكتروني التي تدمج ما بين فن القصص وتكنولوجيا الوسائط المتعددة الغنية بالمثبرات منل الصور الثابتة والمتحركة والنصوص والفيديوهات والموسيقى وذلك لتقديم معلومات حول مفهوم محدد. (نبفين أحمد،

كما تعد القصص الإلكترونية إحدى التقنيات الحديثة التي تصمم وتتتج وتعرض

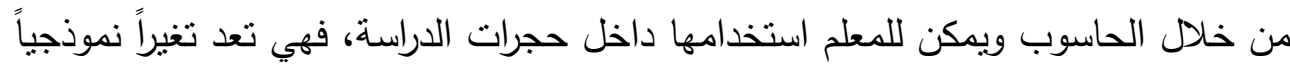
في مجال التعليم، حيث تنقل الطريقة التقليدية في التعليم خاصة مع الأطفال إلى التركيز على عمليات التعلم العليا مثل الفهم والإبداع، وتقدم للأطفال المعلومة من خلال برامج متكاملة، هذا بالإضافة إلى الألوان والحركات والمثيرات الصوتية، وبذلك فهي تعد نموذجاً من نماذج التعلم الإلكتروني إذا ما وضع في الاعتبار مجموع ما تكونه القصة من نموذج الإنج

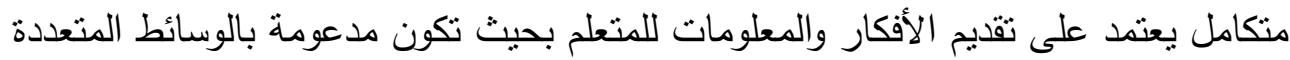

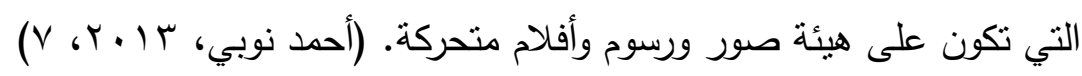

والقصص الإلكترونية قصص واسعة الانتشار بأثكالها المختلفة حيث إنها تتميز

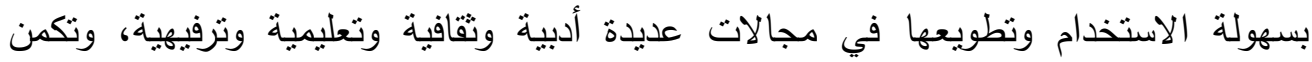

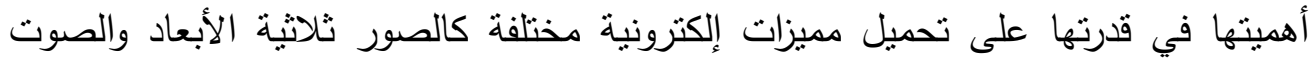
والحركة حيث تعد شكلاً أدبياً يحمل خصائص إلكترونية، وهى تخضيل فئه لمعايير وشروط القصنة

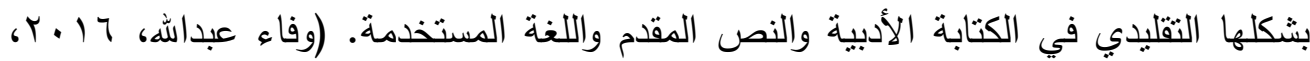
ror)، وتعد من الوسائل الفعالة في تكوين شخصية الطفل وتربية ذوقه وخياله وتهذيب خلقه وهى طريقة لتربيته وتعليمه حيث يكتسب عن طريقها المعارف والمعلومات والاتجاهات

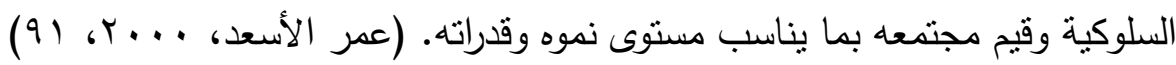




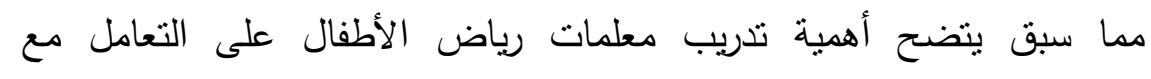
المستحدثات التكنولوجية, والإطلاع على كل ما هو جديد في مجال تكنولوجيا التعليم لتفعيل

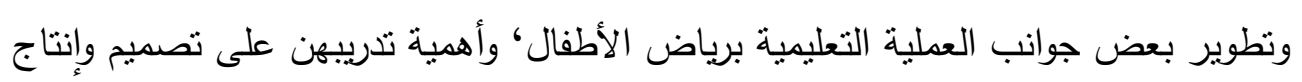

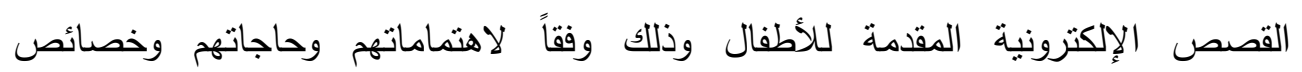

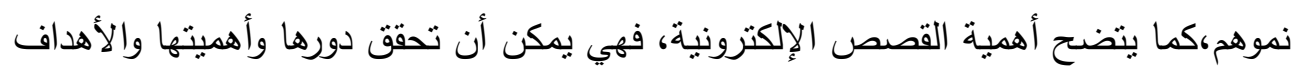

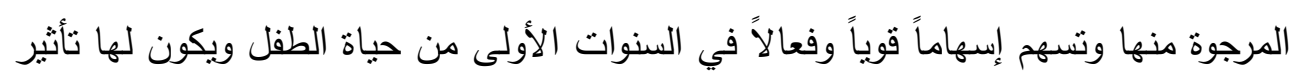

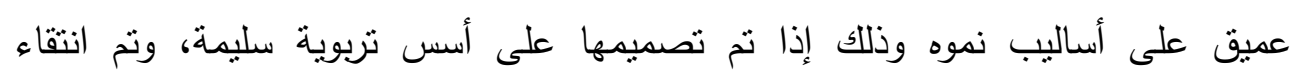

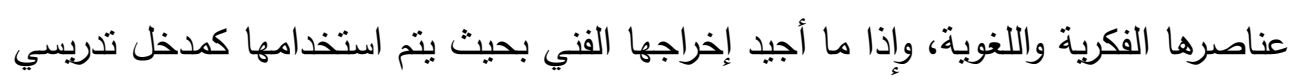

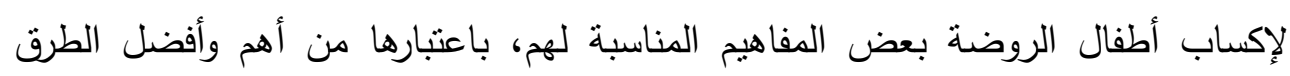

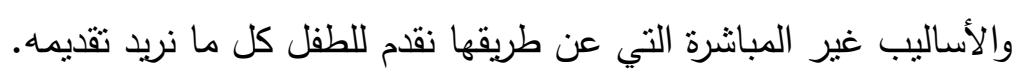

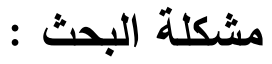

نبع إحساس الباحثة بمشكلة البحث من خلال عدة مصادر أساسية أهمها:

1- الزيارات الميدانية :التي قامت بها الباحثة لعدد كبير من الروضات وحضور الباحثة

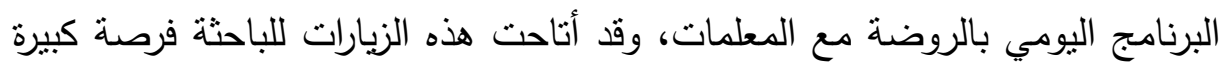

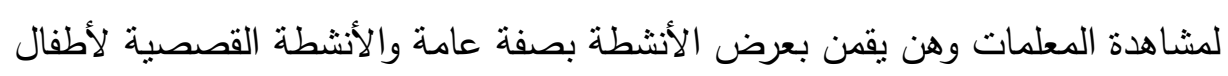
الروضة بصفة خاصة وقد لاحظت الباحثة الآتي :

• إتباع المعلمات الطرق التقليدية فى عرض وتقديم الأنثطة القصصية للأطفال

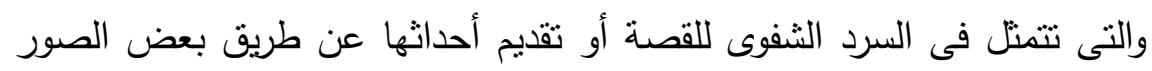

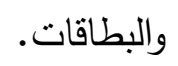

• عدم قدرة المعلمات على مسايرة النطور التكنولوجي واستخدام القصص الإكترونية

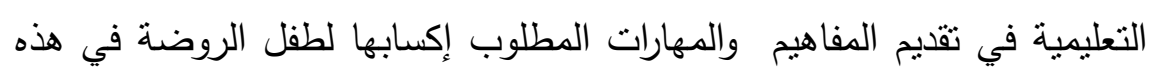
المرحلة. 
عدم معرفة المعلمات بالبرامج والمواقع المتخصصة والمستخدمة في تصميم وإنتاج القصص الإلكترونية.

عدم معرفة المعلمات بمراحل وخطوات تصميم وإنتاج القصص الإلكترونية مما ترتب عليه عدم قدرة المعلمات على تصميم القصص الإككترونية التعليمية المناسبة لطفل الروضة واستخدامها في إكساب الأطفال مجموعة من المفاهيم

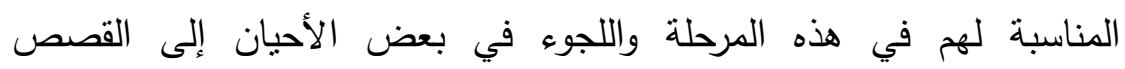

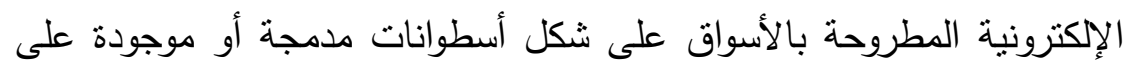

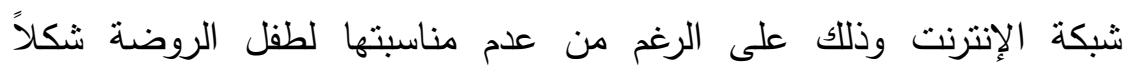
وموضوعاً لأن الهدف الأساسي منها تجارى وتسويقي وليس تعليمي، فهي تفتقر إلى وجود معايير لجودة محتواها وأسس إعدادها وتصميمها. عدم معرفة المعلمات بمنطلبات تقديم القصص الإكترونية لطفل الروضة وكيفه التخطيط لعرضها.

إغفال معلمات رياض الأطفال دور الوسائط التكنولوجية في عرض القصص على الأطفال لإضفاء جو من المتعة والترفية بل ما زال الإصرار على استخدام الطرق التقليدية العادية في سرد القصة. الغالبية العظمى من المعلمات لا يوجد لديهن دافع لتوظيف التكنولوجيا في تقديم الأنشطة بصفة عامة والأنشطة القصصية بصفة خاصة وذلك لعدة أسباب منها: قصور في إعداد المعلمات قبل الخدمة،حيث لم يسبق للمعلمات دراسة مقررات تمثل الخلفية المعرفية لهن في مجال تصميم وتتفيذ بعض الأنشطة التكنولوجية المناسبة لطفل الروضة بصفة عامة وتصميم وإنتاج القصص الإكترونية

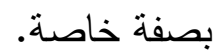

عدم توافر برامج لتدريب معلمات رياض الأطفال على تفعيل التعليم الإلكتروني

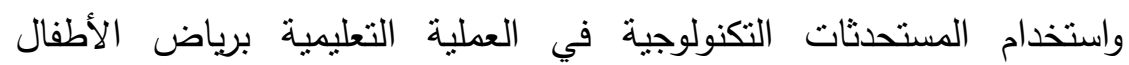
وتوظيفها في الأنشطة المقدمة لطفل الروضة. 
استخدام التكنولوجيا في تصميم وإنتاج القصص الإلكترونية بتطلب كفاءة عالية والغالبية العظمى من المعلمات لا يمتلكن كفاءة استخدام التكنولوجيا وتوظيفها. • نظرة كثير من المعلمات للتكنولوجيا على إنها أداة للتسلية والترفية وليست للتعليم مما يجعلهن يعرضن عن استخدامها.

r- الدراسة الاستطلاعية: لتدعيم صدق إحساس الباحثة بالمشكلة قامت بإجراء دراسة

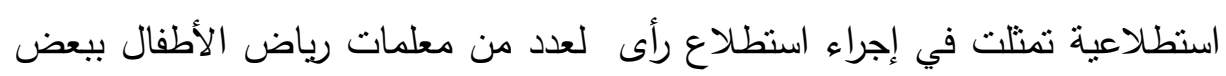

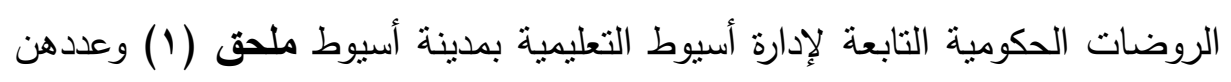
(^) معلمة وذللك للتعرف على واقع معرفة معلمات رياض الأطفال بمهارات تصميم

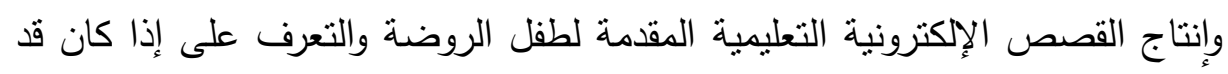

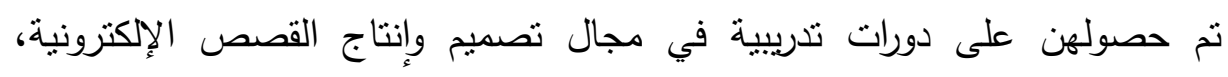

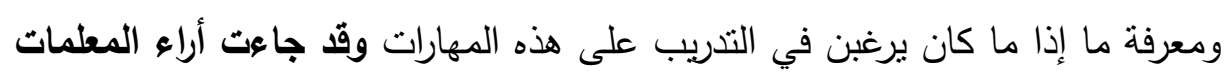

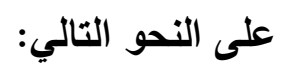
• أجمع . 1\% من المعلمات على عدم معرفتهن بمهارات تصميم وإنتاج القصص الإكترونية التي يجب أن تستخدمها معلمات رياض الأطفال عند

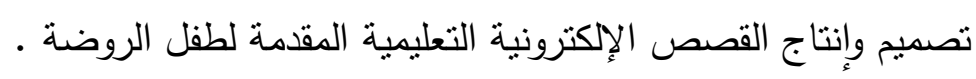

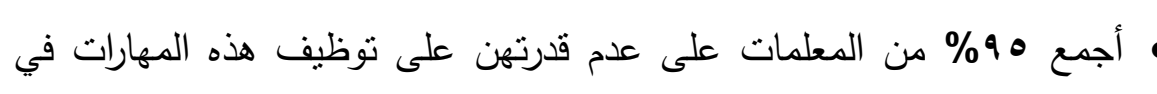

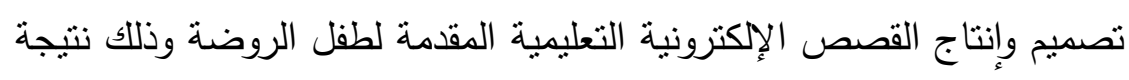

$$
\text { لوجود قصور في برامج إعدادهن بالكلية. }
$$

• أجمع . 1 \% من المعلمات على عدم حصولهن على دورات تدريبية في مجال تصميم وإنتاج القصص الإككترونية التعليمية المقدمة لطفل الروضة.

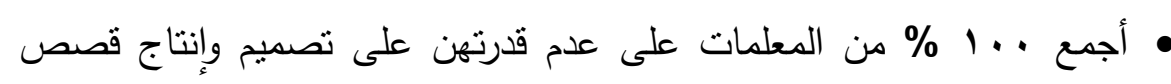
إلكترونية تعليمية لطفل الروضة. 
• أجمع •^\% من المعلمات على رغبتهن في التدريب على هذه المهارات وأكدوا

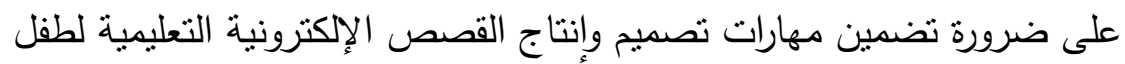

$$
\text { الروضة في برامج تدريب معلمات رياض الأطفال. }
$$

r- توصيات العديد من الاراسات والبحوث السابقة: التي أوصت باستخدام القصص الإلكترونية في بناء مناهج رياض الأطفال مما يثري العملية التعليمية،وتضمين برامج

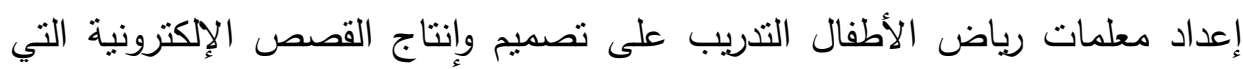
تتاسب طفل الروضة، كما أوصت بضرورة نشر ثقافة القصة الإككترونية ما بين الأوساط

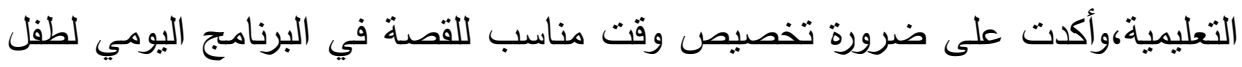
الروضة تقدم خلاله القصص الإلكترونية التعليمية المناسبة لهم، ومن هذه الدراسات

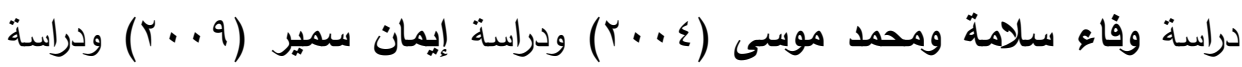

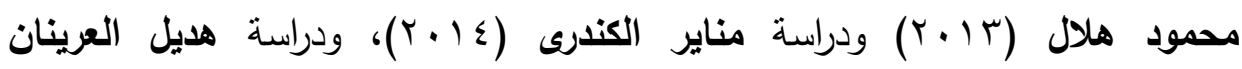

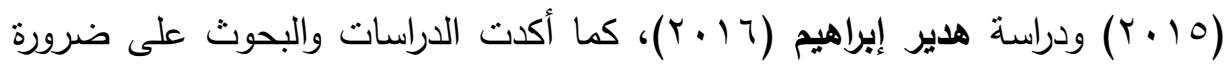
الاهتمام بتدريب معلمات رياض الأطفال على تصميم وتتفيذ بعض الأنشطة التكنولوجية المناسبة لطفل الروضة، واطلاعهم على أهم المستجدات على الساحة التعليمية في مجال

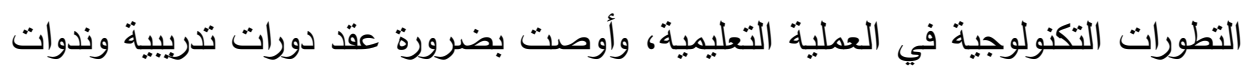
وورش عمل مستمرة لتدريب المعلمات على كل ما يستجد من تقنيات التعليم والاهتمام بتدريب المعلمات على تصميم القصص الإكترونية لتتمية قدراتهم المهنية ومسايرة التطورات والمستحدثات التكنولوجية التعليمية التي تؤدى إلى جودة العملية التعليمة برياض الأطفال، ومن هذه الدراسات دراسة سماح مرزوق (10 ب ب)، كما أوصت دراسة

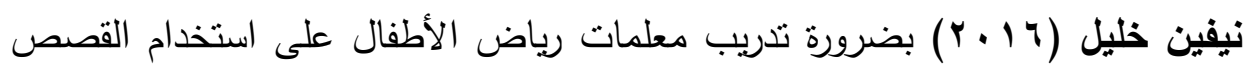
الإلكترونية في الممارسات التعليمية وتصميم القصص الإلكترونية التعليمية لاستخدامها في التدريس لأطفال الروضة، وضرورة تشجيع معلمات رياض الأطفال على استخدام التعلم الإكتروني في العملية التعليمية برياض الأطفال. 
ع-توصيات العديد من المؤتمرات: التي تتاولت إعداد وتدريب معلمات رياض الأطفال

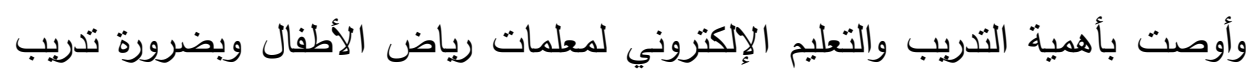

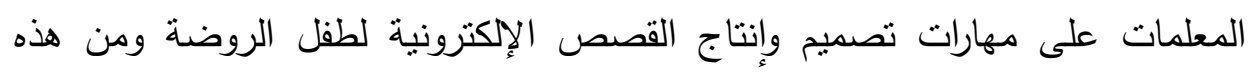

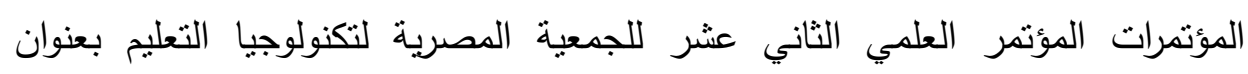

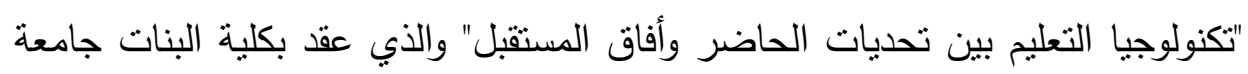

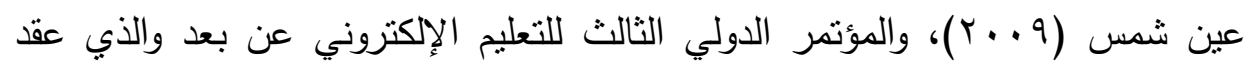

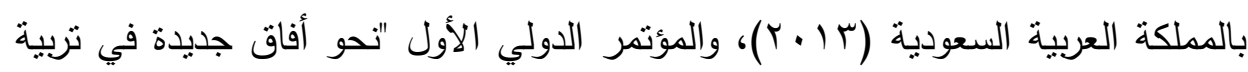

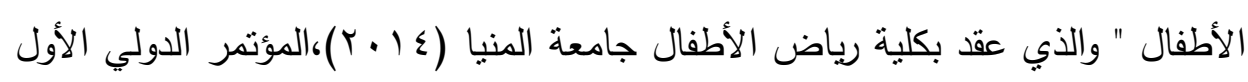

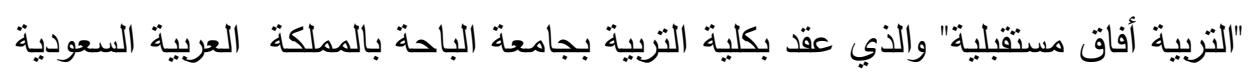

$$
\cdot(r \cdot 10)
$$

في ضوء ما سبق أمكن تحديد مشكلة البحث في عدم معرفة معلمات رياض

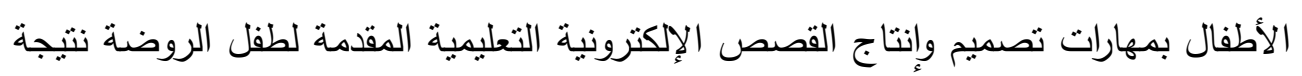

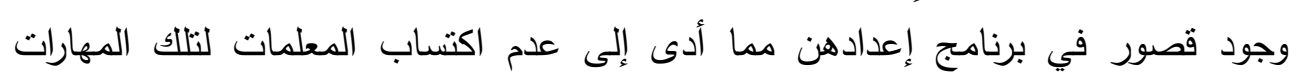
بالإضافة إلى عدم وجود برامج تدريبية لتدريب المعلمات على هذه المهارات. لذا هدف البحث الحالي إلى تقديم برنامج تدريبي لمعلمات رياض الأطفال لتتمية

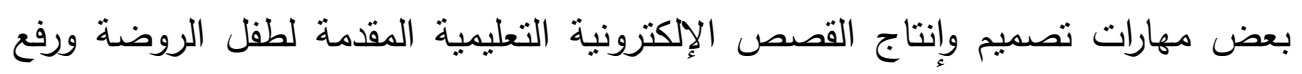
كفاءتهن وأدائهن المهني والوظيفي وتقديم هذه المهارات بشكل يساعدهن على التمكن من التهني تصميم وإنتاج القصص الإكترونية التعليمية بكفاءة عالية وأداء منميز ل

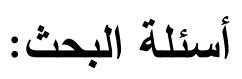

\section{تثير مشكلة البحث الأسئلة التالية :}

1- ما المهارات الأساسية اللازم توافرها لدى معلمات رياض الأطفال لتصميم وإنتاج القصص الإلكترونية التعليمية المقدمة لطفل الروضة ؟ توانه r - ما واقع معرفة معلمات رياض الأطفال بمهارات تصميم وإنتاج القصص الإلكترونية

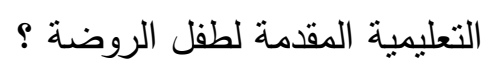


r- ما المعايير التربوية والفنية والتقنية التي يتم في ضوئها تصميم وإنتاج القصص الإلكترونية التعليمية المقدمة لطفل الروضة ؟بله

ع - ما التصور المقترح لبرنامج تدريبي لمعلمات رياض الأطفال لتتمية بعض مهارات

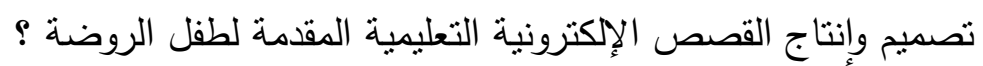
ه- ما فاعلية البرنامج التدريبي في إكتساب معلمات رياض الأطفال للجانب المعرفي

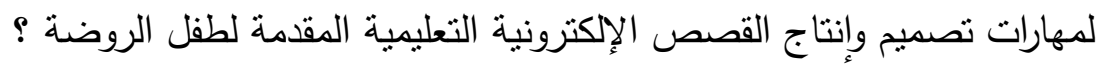
צ- ما فاعلية البرنامج التدريبي لمعلمات رياض الأطفال في تتمية بعض مهارات تصميم وإنتاج القصص الإلكترونية التعليمية المقدمة لطفل الروضة؟ لئج V- ما فاعلية البرنامج التنريبي في تحقيق المعايير التربوية والفنية والتقنية الخاصة

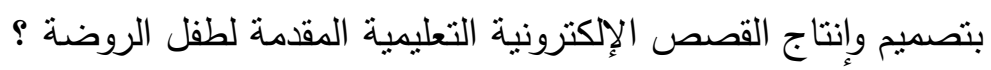

\section{يهدف البحث الحالي إلى:}

1- تحديد المهارات الأساسية اللازمة لمعلمات رياض الأطفال لتصميم وإنتاج القصص الإكترونية التعليمية المقدمة لطفل الروضة.

r - التعرف علي واقع معرفة معلمات رياض الأطفال بمهارات تصميم وإنتاج القصص الإككترونية التعليمية المقدمة لطفل الروضة.

r- تحديد المعايير التربوية والفنية والتقنية التي يتم في ضوئها تصميم وإنتاج القصص الإكترونية التعليمية المقدمة لطفل الروضة. ـ - إعداد برنامج تدريبي لمعلمات رياض الأطفال لتتمية بعض مهارات تصميم وإنتاج القصص الإكترونية التعليمية المقدمة لطفل الروضة. ه- التعرف على فاعلية البرنامج التدريبي في إكساب المعلمات للجانب المعرفي لكهارات تصميم وإنتاج القصص الإكترونية التعليمية المقدمة لطفل الروضة. 
צ- التعرف على فاعلية البرنامج التدريبي لمعلمات رياض الأطفال في تتمية بعض التصات مهارات تصميم وإنتاج القصص الإلكترونية التعليمية المقدمة لطفل الروضة. V- التعرف على فاعلية البرنامج التدريبي لمعلمات رياض الأطفال في تحقيق المعايير التربوية والفنية والتقنية الخاصة بتصميم وإنتاج القصص الإكترونية التعليمية المقدمة لطفل الروضة.

\section{أهمية البحث:}

\section{تمثلت أهمية البحث الحالي فيما يلي:}

\section{أولاً الأهمية النظرية:}

1- يقدم البحث معلومات نظرية عن القصص الإككترونية، وكذلك الجوانب المعرفية

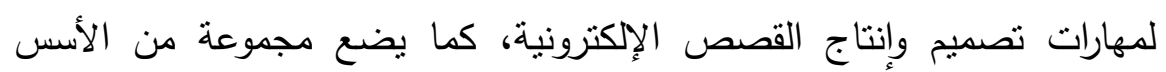

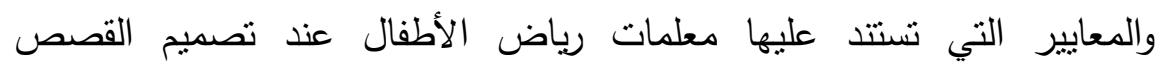
الإكترونية التعليمية المقدمة لطفل الروضة.

r- يقدم البحث قائمة بالمهارات الأساسية اللازمة لمعلمات رياض الأطفال لتصميم

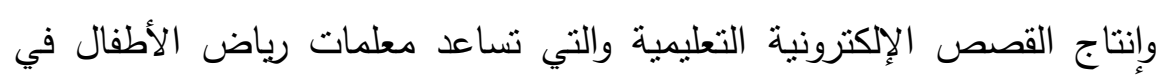

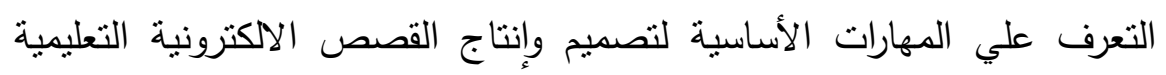
المقدمة لطفل الروضة.

ب- يقدم البحث قائمة بالمعايير التربوية والفنية والتقنية التي يتم في ضوئها تصميم

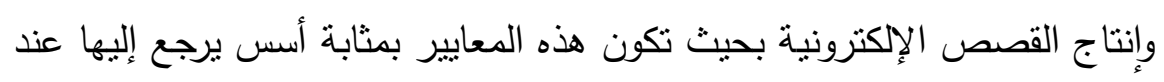

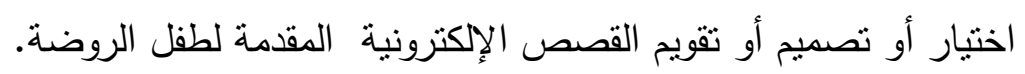
؛ - قد يفتح البحث الحالي المجال أمام دراسات وبحوث أخرى في مجال تدريب

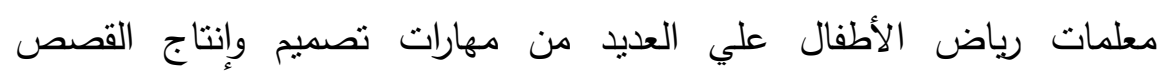
الإكترونية التعليمية المناسبة لطفل الروضة. 
ه- التوصل إلى مجموعة من النتائج يمكن الإفادة منها في تدريس مقرر طرق رواية

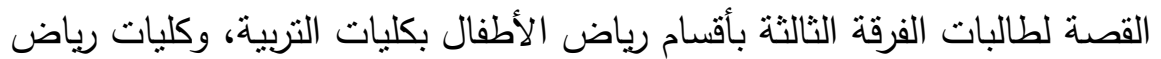

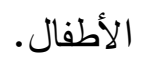

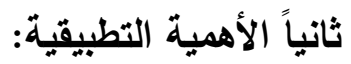

1- يفيد البحث المهتمين وجميع القائمين على تدريب معلمات رياض الأطفال حيث يعد البرنامج التدريبي بمثابة محور رئيس يمكن تضمينه للبرامج التدريبية المقدمة

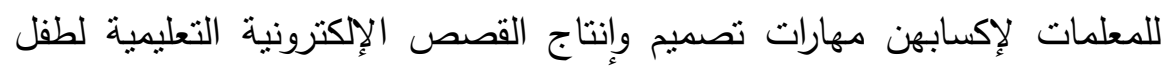

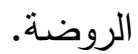

r- يقدم البحث لمعلمات رياض الأطفال نماذج من القصص الإكترونية التعليمية

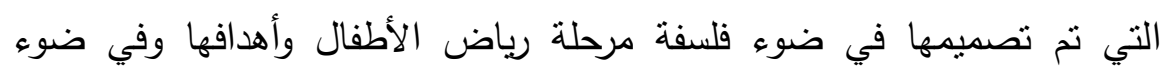

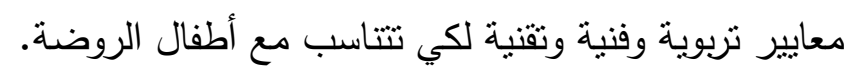

r- تزويد أخصائي تكنولوجيا التعليم ومعلمات رياض الأطفال وجميع القائمين على الى التهات اختيار وتصميم وإنتاج وتقويم القصص الإلكترونية بقائمة المعايير التربوية والفنية والتقنية التي يتم في ضوئها تصميم وإنتاج القصص الإلكترونية المقدمة لطفل

$$
\text { الروضة. }
$$

ع - يقدم البحث برنامجاً تدريبياً يسهم في تتمية ورفع كفاءة معلمات رياض الأطفال

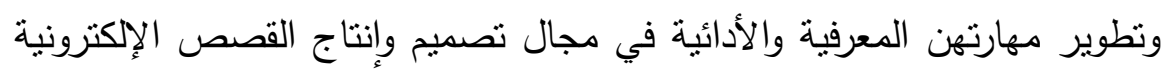
التعليمية لطفل الروضة.

تحدد مجال البحث الحالي بالحدود التالية:

1- الحدود البشرية:أجري البحث على مجموعة من معلمات رياض الأطفال ببعض

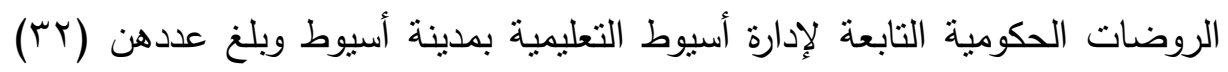

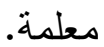


r- الحدود المكانية: تم تطبيق أدوات البحث والبرنامج التدريبي بروضة مدرسة الزهراء الابتدائية، وهي تابعة لإدارة أسيوط التعليمية بمدينة أسيوط.

r- الحدود الزمانية: تم تطبيق البرنامج على ددى (ع؟) جلسة بمعدل ثلاث جلسات

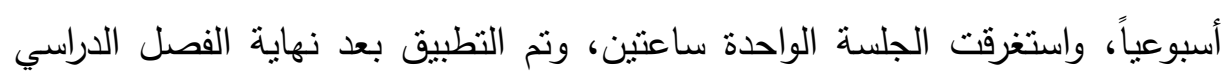

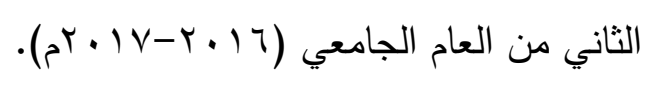

ـ - الحدود الموضوعية : اقتصرث الحدود الموضوعية للبحث علي تدريب معلمات رياض

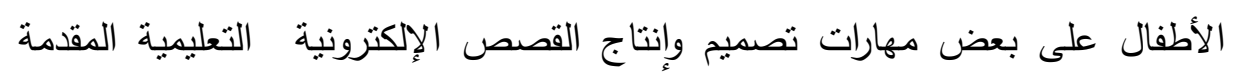

$$
\text { لطفل الروضة وذلك من خلال: }
$$

دراسة الجوانب النظرية والمعرفية: لمهارات تصميم وإنتاج القصص

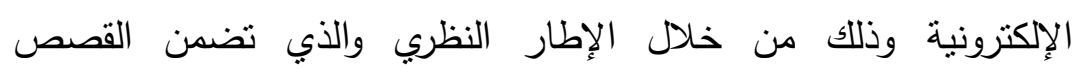
الإكترونية ومفهومها وأهميتها في العملية التعليمية برياض الإل الأطفال

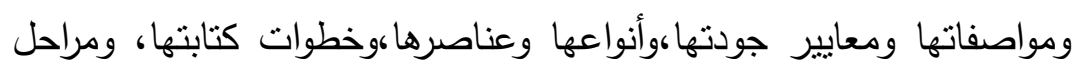
إنتاجها، والبرمجيات والمواقع المستخدمة في تصميمها. دراسة الجوانب التطبيقية والعملية: لـهارات تصميم وإنتاج القصص الإلكترونية التعليمية المقدمة لطفل الروضة وذللك من خلال جلسات البرنامج التدريبي ومحتواه والأساليب المستخدمة في تدريسه. ا قتصر البحث الحالي على تدريب المعلمات على المهارات التالية: (مهارات ما قبل تصميم وإنتاج القصص الإلكترونية)، (مهارات التصميم والإنتاج

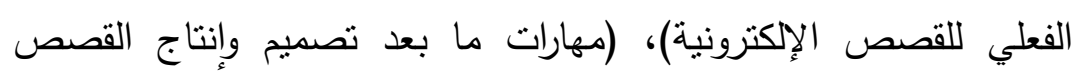
الإلكترونية).

كما اقتصر البحث الحالي على استخدام موقع الباوتون powtoon لتدريب

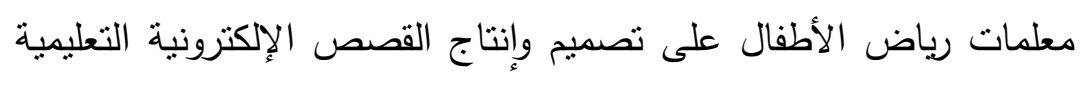
المقدمة لطفل الروضة. 
استخدمت الباحثة المنهج الوصفي التحليلي لرصد واقع معرفة معلمات رياض التهاض

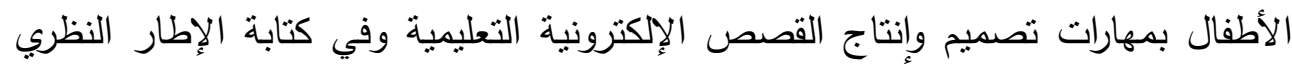

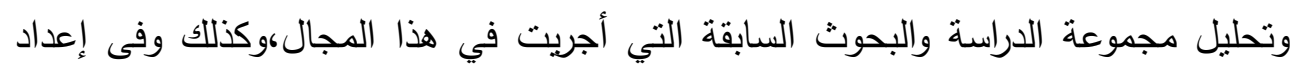
أدوات البحث وعند تحليل وتقسير النتائج، كما استخدمت الباحثة المنهج شبه التجريبي التهي

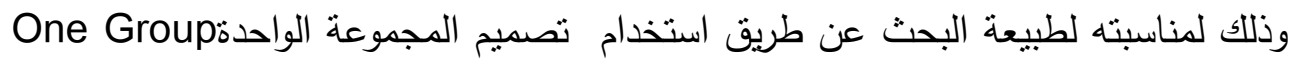
ذات القياسين القبلي والبعدي علي نفس المجموعة باعنباره أفضل تصميم تجريبي يناسب لهبن

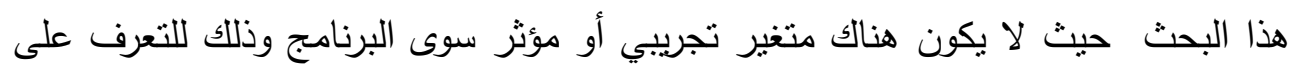

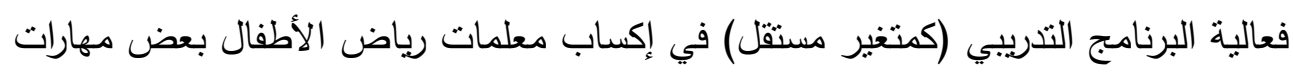
تصميم وإنتاج القصص الإكترونية كمتغير (تابع). أدوات ومواد البحث: - n

\section{قامت الباحثة بإعداد الأدوات التالية :}

1 - قائمة بالمهارات الأساسية اللازمة لمعلمات رياض الأطفال لتصميم وإنتاج القصص الإلكترونية التعليمية المقدمة لطفل الروضة. (إعداد الباحثة)

r - قائمة بالمعايير التربوية والفنية والتقنية التي يتم في ضوئها تصميم وإنتاج القصص الإلكترونية التعليمية المقدمة لطفل الروضة. (إعداد الباحثة) r- اختبار لقياس الجانب المعرفي لدى معلمات رياض الأطفال في تصميم وإنتاج القصص الإلكترونية التعليمية المقدة لطفل الروضة. (إعداد الباحثة) ؟ - بطاقة ملاحظة أداء معلمات رياض الأطفال لقياس الجانب الأدائي والمهاري لمهارات تصميم وإنتاج القصص الإكترونية التعليمية المقدمة لطفل الروضة. (إعداد الباحثة) 
ه- بطاقة تقييم منتج القصص الإككترونية التي تم تصميمها في ضوء المعايير التربوية والفنية والتقنية لتصميم القصص الإكترونية التعليمية المقدة لطفل الروضة. (إعداد الباحثة)

צ-برنامج تدريبي لمعلمات رياض الأطفال لتتمية بعض مهارات تصميم وإنتاج

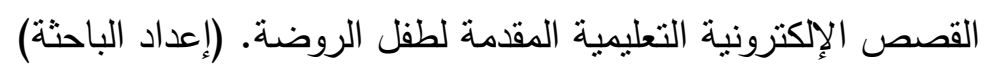

\section{المصطلحات الإجرائية للبحث :}

1- الفاعلية:Effectiveness : ويقصد بها مدى تأثير المتغير المستقل(البرنامج التدريبي) على المتغير التابع (إكساب معلمات رياض الأطفال بعض مهارات تصميم وإنتاج القصص الإكترونية التعليمية لطفل الروضة).

r training program: تعرف البرنامج التدريبي إجرائيا على إنه خطة زمنية منظمة ومحددة الأهداف والمحتوى واستراتيجيات

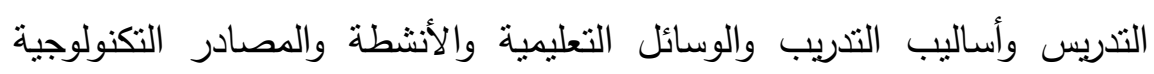

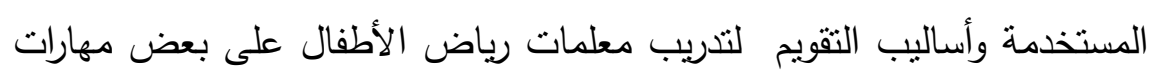

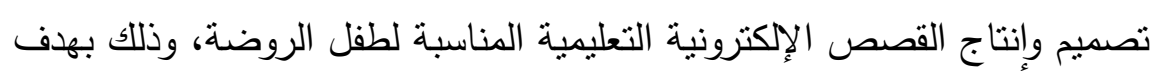

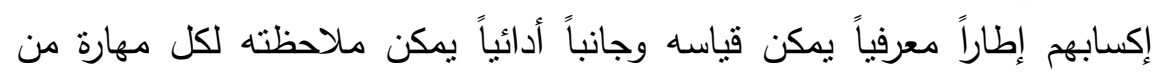
المهارات المحددة بالبرنامج.

r- معلمات رياض الأطفال: kindergarten Teacher وتعرف إجرائيا على إنهما

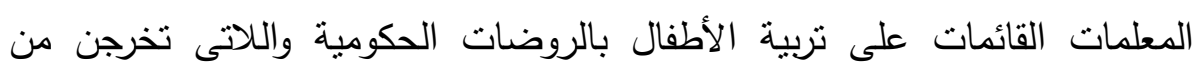
كليات رياض الأطفال أو كليات التربية (أقسام تربية الطفل) ويمارسن العمل بلرونات بالروضات بمدينة أسيوط لتحقيق التتمية الثاملة والمتكاملة للأطفال فى هذه المرحلة.

צ - مهارات تصميم وإنتاج القصص الإكترونية: Skills of designing and

producing Digital stories والممارسات التي ينبغي أن تتبعها وتقوم بها معلمات رياض الأطفال قبل وأثناء وبعد تصميم وإنتاج القصص الإكترونية والقدرة على توظيف كافة المستحدثات

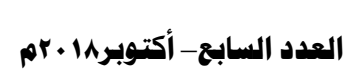


التكنولوجية الحديثة بكفاءة عالية من أجل تصميم قصص إلكترونية تعليمبة مناسبة لطفل الروضة.

ه- القصص الإكترونية:Digital stories تعرف الباحثة القصص الإلكترونية بأنها مجموعة من الحكايات والقصص التعليمية يتم تصميمها وإنتاجها وفق معايير

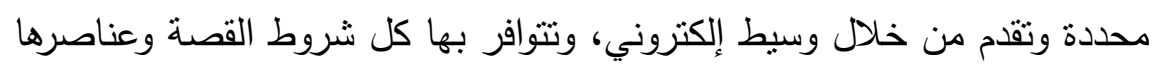

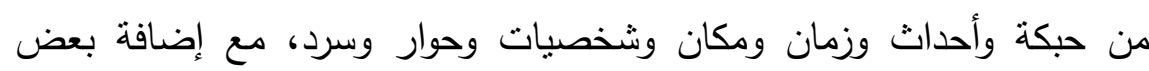

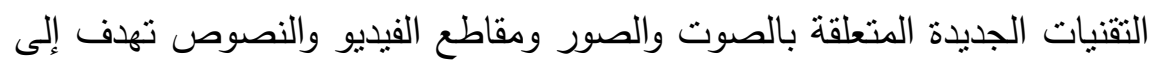
تتمية بعض الجوانب الإيجابية للطفل وتحقيق أهداف مرحلة رياض الأطفال وتقدم بشكل إلكتروني فيه إنارة ومتعة وتتشويق.

الإطار النظري للبحث ودراساته السابقة ويتناول المحاور التالية: المحورالأول: تدريب معلمات رياض الأطفال: مفهوم تدريب معلمات رياض الأطفال. توجد تعريفات عديدة لتدريب معلمات رياض الأطفال وفيما يلي تستعرض الباحثة بعض هذه التعريفات

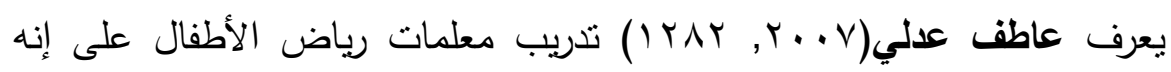
عملية منظمة مستمرة محورها معلمة الروضة , حيث تقدم لها مجموعة من البرامج التي

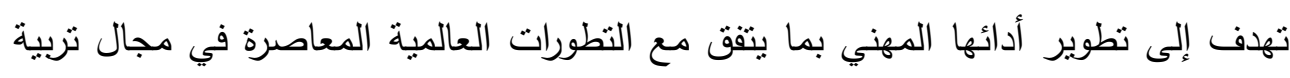
الطفل واحتياجاتها التدريبية.

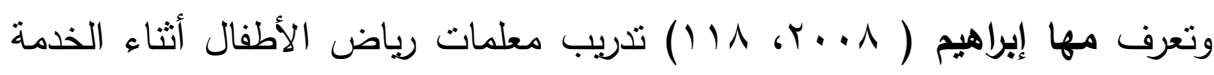

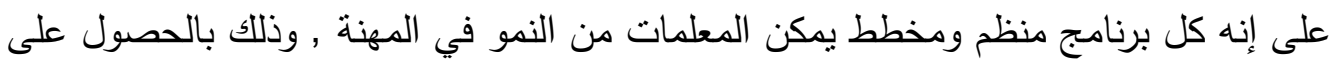
مزيد من الخبرات الثقافية والسلوكية وكل ما من شأنه أن برفع مستوى عملية التعليم والتعلم.

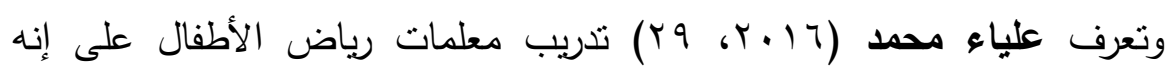
مجموعة العمليات التربوية المخططة والمنظمة التي تستكمل التطور المهني للمعلمة وتهدف 


\section{المجلة العلمية لكلية رياض الاطفال - جامعة اسيوط}

إلى إثراء معارفهن وزيادة خبراتهن ورفع مستوى أدائهن والإطلاع على كل ما هو جديد في

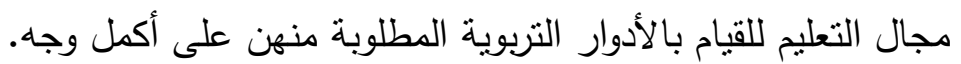

مما سبق يتضح أن تدريب معلمات رياض الأطفال عبارة عن برنامج منظم ومخطط يهدف إلي التحسن المستمر في مستوى أداء المعلمات ويزودهن بالخبرات

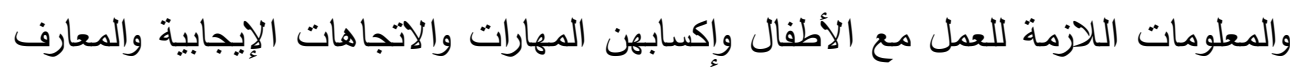
والمعلومات التي تساعدهن علي القبام بأعباء وظيفتهن وتسهح في رفع مستوى أدائهن في الوقت الحاضر والمستقبل وتزودهن بالاتجاهات والتطورات الحديثة في مجال تربية الطفل.

\section{أهمية تلديب معلمات رياض الأطفال :}

التدريب سمة من سمات العصر وضرورة لازمة لمقابلة احتباجات الفرد في النمو المهني ,ولتدريب معلمات رياض الأطفال أهمية خاصة، لأنه يعد مكملاً لإعدادهم قبل

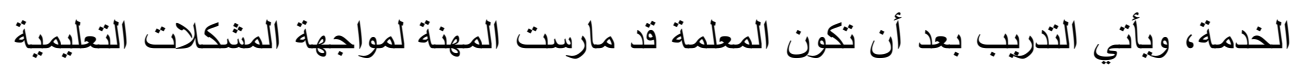
التي تتعرض لها، ومن أجل تزويدها بالخبرات والمهارات التعليمية التي تمكنها من القيام

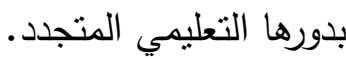

ويعد تدريب معلمات رياض الأطفال أحد وسائل تحسين أداء المعلمات وذلك لاستيعاب كل ما هو جديد ومستحدث في المعرفة المهنية والأداء المهني، حيث إن اكتفاء معلمات رياض الأطفال بما اكتسبوه خلال سنوات إعدادهن من معرفة ومعلومات ومهارات لا يكفى لتجويد أدائهن في جوانبه التخصصية والمهنية والثقافية.

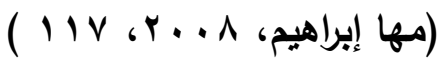

وتواجه معلمة رياض الأطفال في القرن الحادي والعشرين تحديات تكنولوجية قد تعوقها عن نموها المهني، كما أن برامج التدريب التقليدية لا يمكن لها في عصر فئه يحفل

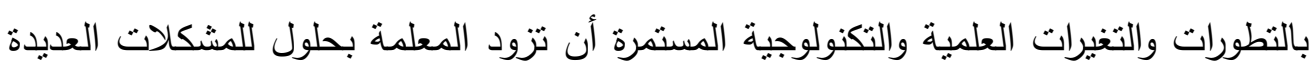

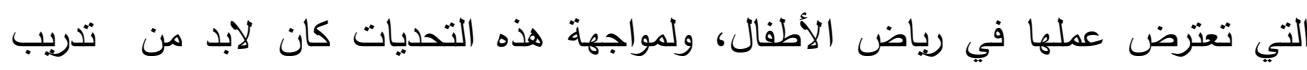

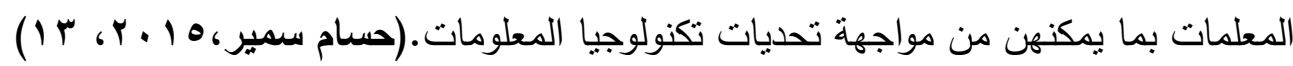


مما سبق يتضح أهمية تدريب معلمات رياض الأطفال،فهو علية ضرورية وحتمية وأساسية في تتمية المعلمات مهنياً وعلمياً وثقافياً، واطلاعهن على الاتلى الاتجاهات والأساليب

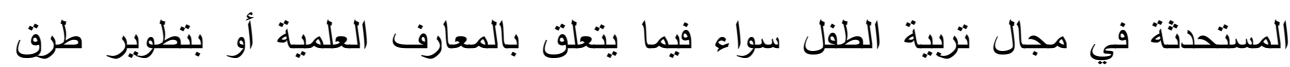
التدريس والارتقاء بأداء المعلمة نحو الأفضل.

المحور الثاني: القصص الإكترونية ومفهومها وأهميتها، وأنواعها وعناصرها، ومواصفاتها ومعايير جودتها ومميزات استخدامها، وخطوات كتابتها، ومراحل إنتاجها، والبرمجيات المستخدمة في تصميمها. تعريف القصص الإلكترونية:

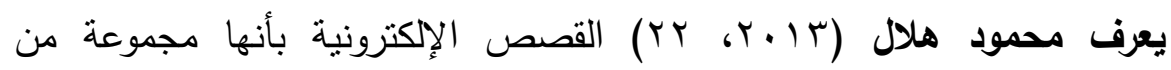
القصص الهادفة المتوفر فيها عناصر القصة من أحداث وشخصيات وعقدة وزمان ومكان وسرد وحوار وتقام من خلال وسيط إلكتروني (الكمبيوتر) أومن خلال أسطوانات الليزر أو ونئ وعندان

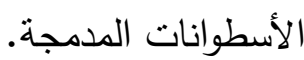

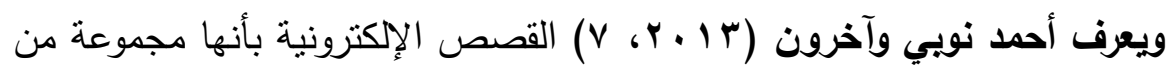

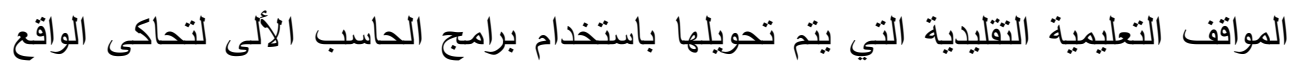
بالصوت والصورة وتصمم الصور بها بالأبعاد الثنائية والثلاثية.

كما تعرف هديل العرينان (10 ب r، 9) القصص الإكترونية بأنها القصص التي

تمت برمجتها على أقراص مدمجة من خلال استخدام بعض التقنيات الحديثة المتعلقة

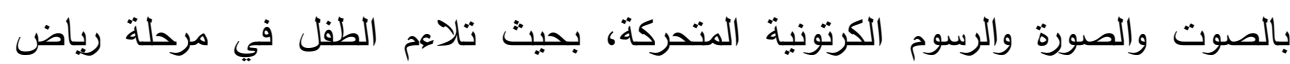
الأطفال وتتاسب ميوله واتجاهاته وتنساعد على تتمية مهاراته اللغوية.

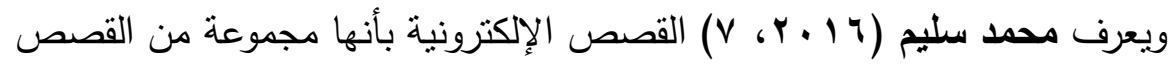

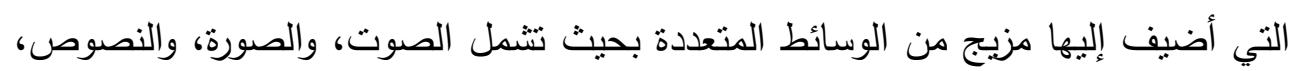
والمؤثرات الصوتية، والرسوم الكرتونية المتحركة، لإنتاج قصص إلكترونية بأسلوب شائق بغرض توظيفها في العملية التعليمية. 


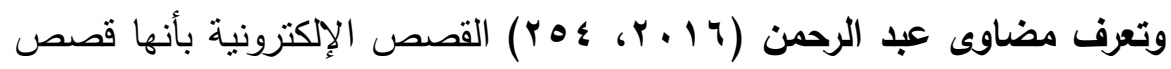
على شكل برمجيات إلكترونية تعمل على وسيط إلكتروني وهو الأسطوانات المدمجة

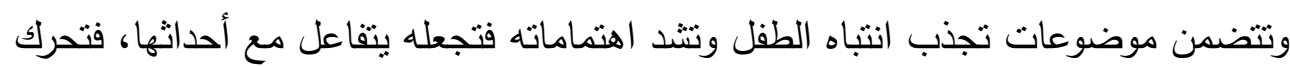
مشاعره وتثثير انفعالاته وتساعده على أن يتقمص شخصيات نجاتهاه كما ذكرت العديد من الدراسات والبحوث الأجنبية تعريفات متعددة للقصص

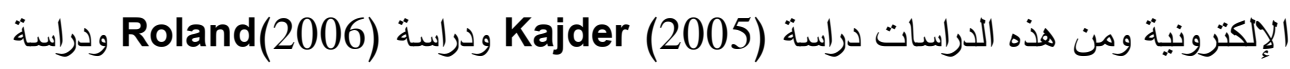

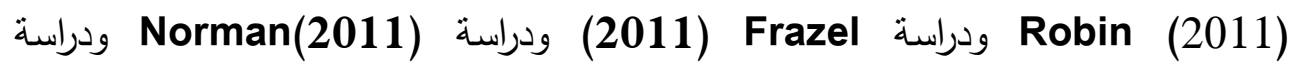
Clark\& Adam (2012) ودراسة (Spicer(2013) Angle(2011)

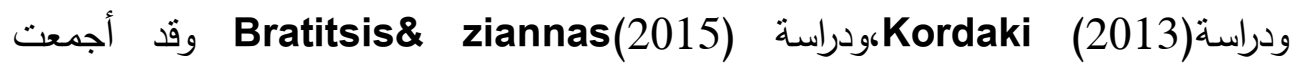
الدراسات والبحوث على أن: ت ودرسات - - القصص الإكترونية قصص قائمة على الوسائط المتعددة قد تكون صور ثابتة أو متحركة، بها لقطات فيديو وموسيقى، ونصوص، تأثيرات صوتية، وتكون مصحوبة

$$
\text { بسرد صوتي للقصة. }
$$

- - القصص الإككترونية تعد دمج بين الفن القديم لحكاية القصص مع الاستفادة من مميزات التكنولوجيا الإكترونية الحديثة التي يسهل تعلمها واستخدامها. - - يمكن تشاركها عبر أدوات التواصل المختلفة. - - يمكن حفظها على جهاز الحاسب الألى أو أقراص مدمجة. - - تشبه القصص التقليدية في التركيز على موضوع محدد ووجهة نظر معينة. من خلال التعريفات السابقة ترى الباحثة أن القصص الإكترونية هي القصص التي أضيف إليها مزيج من الوسائط المتعددة بحيث نتمل الصوت والصور الثابتة والرسوم المتحركة والنصوص لإنتاج قصص إلكترونية بأسلوب شائق بغرض نوظيفها في العملية

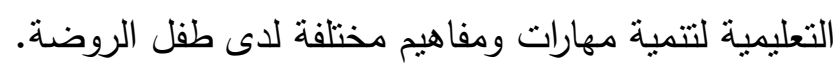


وتعرف الباحثة القصص الإكترونية التعليمية بأنها مجموعة من الحكايات

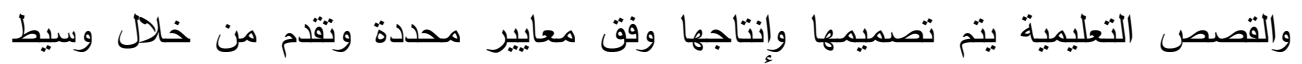
إلكتروني، وتتوافر بها كل شروط القصة وعناصرها من حبكة وأحداث وزمان ومكان وشخصيات وحوار وسرد، مع إضافة بعض التقنيات الجديدة المتعلقة بالصوت والصور

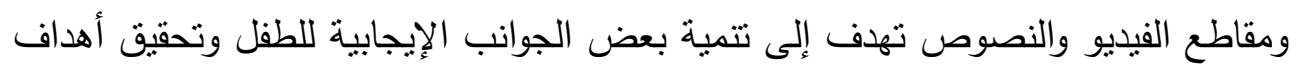
مرحلة رياض الأطفال وتقدم بشكل إلكتروني فيه إثارة ومتعة وتتويق.

الأهمية التريوية للقصص الإكترونية التعليمية :

تمتاز القصة الإكترونية بالعديد من المميزات ولها أهمية كبيرة في العديد من

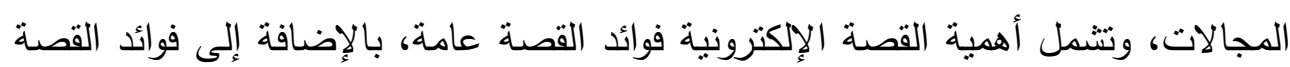
الإككترونية خاصة، وترجع أهية القصة إلى أنها تعد من أكثر الأجناس الأدبية انتشاراً

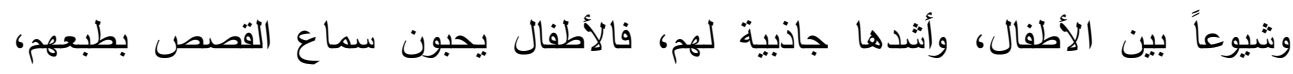

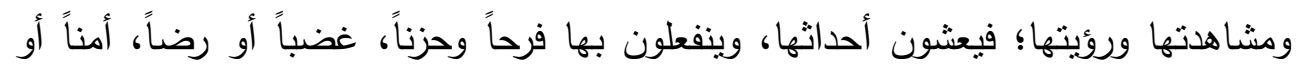

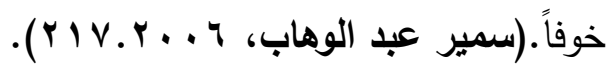

ولقد أكدت العديد من الدراسات والبحوث العربية والأجنبية على أهمية استخدام

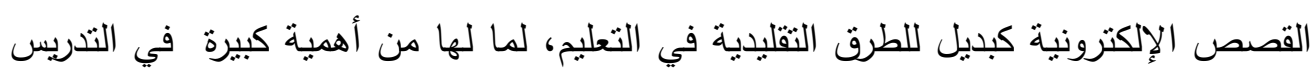
وتعليم طفل الروضة، فهي وسيلة للتحليل التقافي وتعزيز الهوية الاجتماعية والثقافية للأطفال، كما أنها من أفضل الطرق المستخدمة لإكسابهم قيماً دينية وأخلاقية ومفاهيم علمية وتاريخية وجغرافية أو توجيهات سلوكية أو اجتماعية، كما أنها أداة تكنولوجية قوية في القاعات وات الدراسية في القرن الواحد والعشرين فهي تسهم في اكتساب مهارات هذا القرن والتي تعد مزيجاً من

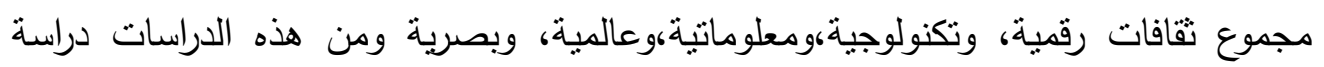

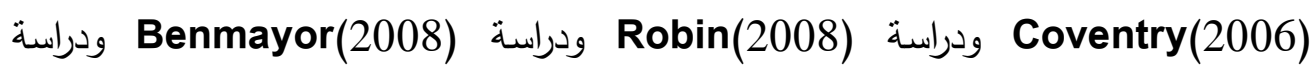
Burkholder \&Cross (2009) .Burch(2010) 
كما أثنارت مجموعة أخرى من الدراسات والبحوث وأكدت على أهمية القصص القص التصات الإلكترونية وفاعليتها في إكساب طفل الروضة بعض المفاهيم العلمية والتاريخية والجغرافية

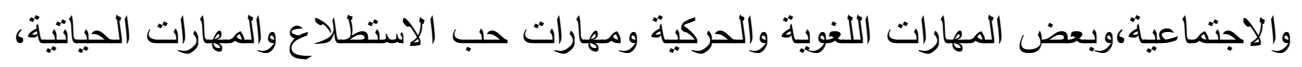

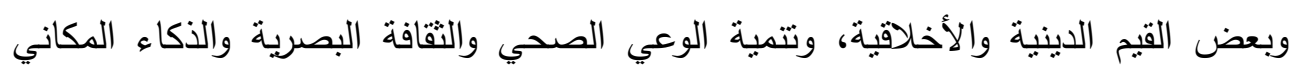

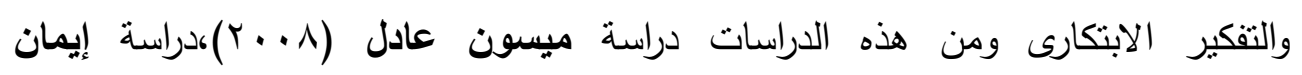

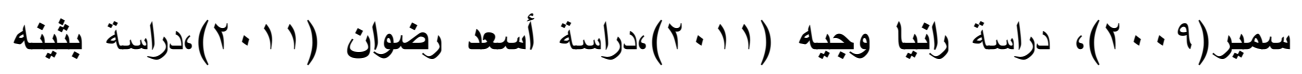

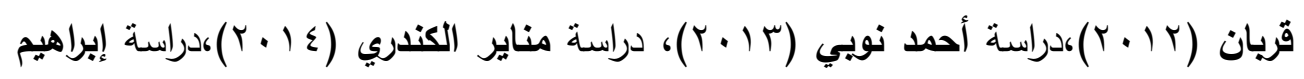

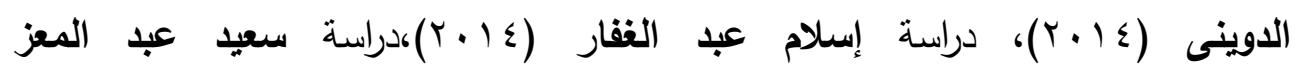

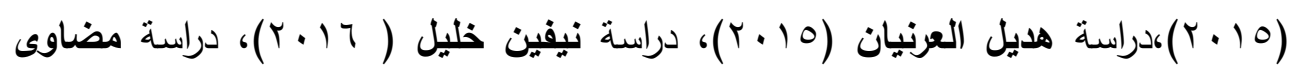

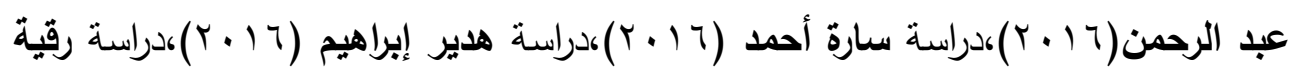

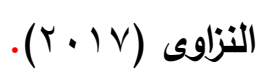

وأكدت دراسة Engle (2011) ودراسة (2011) Candreva على أن للقصص الإكترونية التعليمية أهمية كبيرة في التدريس وتعليم طفل الروضة يمكن توضيحها فيما يلي:

- - تتمى خيال الطفل،وتغذى قدراته،وتنتقل به إلى عوالم جديدة لم تكن لتخطر لله ببال وتجعله يتسلق الجبال ويصعد الفضاء ويقتحم الأحراش ويسامر الوحوش. - - تعمل على إثراء المواقف التعليمية بالمنبهات والمثيرات السمعية والبصرية فينعكس

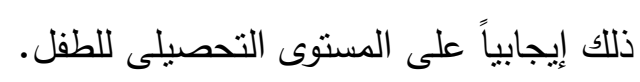
- مواكبه روح العصر والتطور التكنولوجي في العملية التعليمية. - - تساعد على تتمية اتجاهات الأطفال نحو التعلم باستخدام التكنولوجيا. - - تشجع على الإبداع والابتكار . - ـ تعمل على دعم التفكير الناقد لدى الأطفال. - - تعمل على دعم التعلم مدى الحياة. 
- تساعد على جعل التدريس فعالاً، حيث تعمل على دمج الأطفال وتدعيم مشاركتهم ومن ثم يصبح الأطفال مشاركين إيجابيين في العملية التعليمية.

- - التدريس باستخدام القصص الإلكترونية يساعد على تتمية قدرة الطفل على تفسير

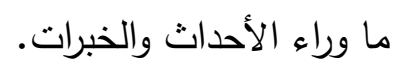

- - التدريس باستخدام القصص الإكترونية بساعد على جذب الانتباه وتتويق عملية

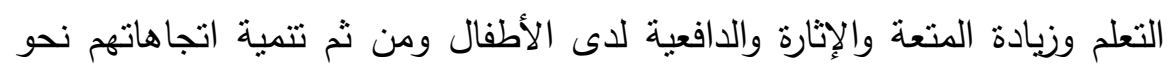

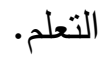

- التدريس باستخدام القصص الإكترونية يساعد على خلق مناخ إيجابي للعملية التعليمية.

وترى الباحثة أنه مما سبق يمكن إجمال الأهمية التربوية للقصص الإلكترونية في

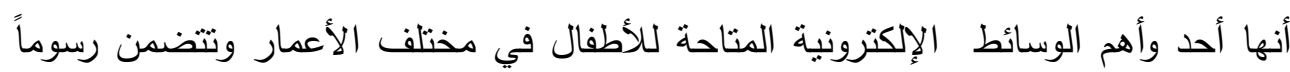
متحركة ومؤثرات صوتية تجذب انتباه الطفل ولها مردود تربوي وتعليمي وتتقيفي في تحسين العملية التعليمية برياض الأطفال.

مميزات القصص الإكترونية: Advantages of using Digital Stories

تعد القصص الإلكترونية أداة قوية وجيدة وفعالة في توصيل المفاهيم المختلفة

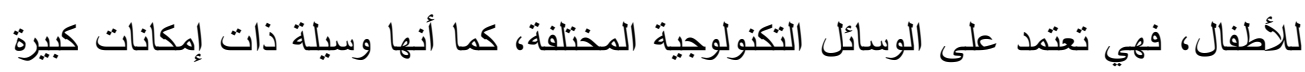

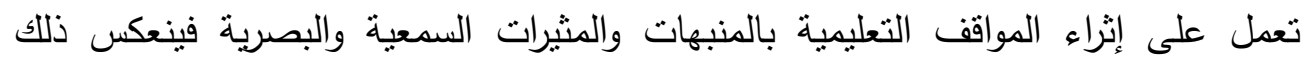

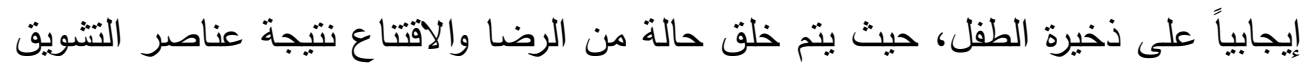

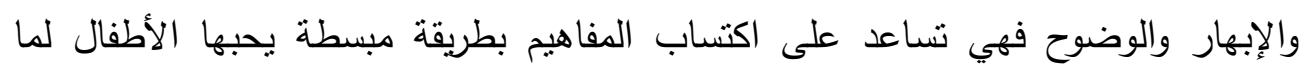
تتميز به القصص الإكترونية من أسلوب شيق وممتع يثير خيال الطفل وينميه.

(Valencia,2012,12)

كما تعد القصص الإلكترونية إحدى الوسائل السمعية والبصرية وتتمتع بنفس مزاياها حيث تعد من أكثر الوسائل إيضاحاً وقدرة على التفسير والتوضيح وتخاطب حاسنة 
البصر أهم وأكثر حواس الطفل استخداماً في اكتساب المعلومات ويضاف عليها الصوت المقترن بصورها المرئية مزيداً من الواقعية ليدل على عمق المشاعر والأحاسيس بل وتعطى لئى

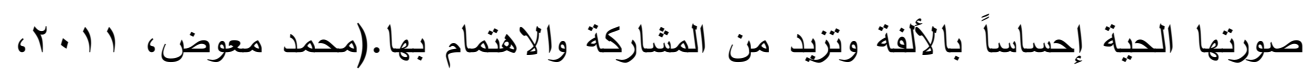

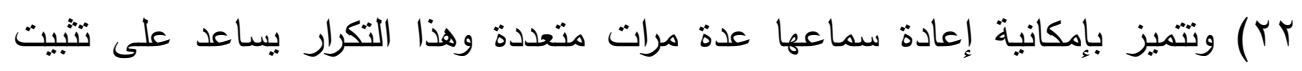

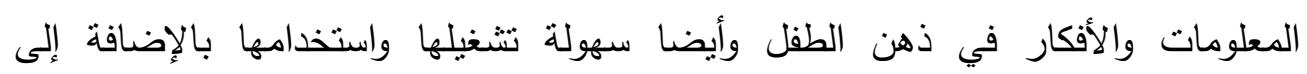
اعتمادها على أكثر من وسيلة فنية وأدبية مثل السرد والحوار والأغاني والموسيقى والمؤثرات

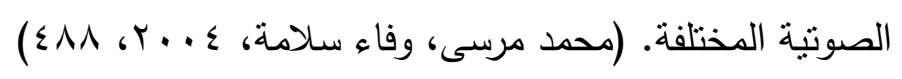

\section{وللقصة الإكترونية التعليمية عدة مزايا منها:}

- تقدم معلومات للطفل ومفاهيم حديثة ومطورة ومبسطة ودقيقة متضمنة في محتوى القصة وتعتمد على الصوت والصورة والحركة والموسيقى والمؤثرات الصوتية.

- - تتسم بوجود حياه قد لا يكون عاشها الطفل أو من الصعب أن يعيشها. - تشوق الطفل وتجذبه من خلال الصور المتحركة والرسوم.(وفاء عبد السلام، (rT r T P )

كما تستمد القصص الإكترونية التعليمية مميزاتها من مميزات الأقراص المدمجة بصفة عامة وهى:

- سعة التخزين عالية حيث يمكن أن يخزن بالقرص 'CD-ROM" أكثر من (10) -

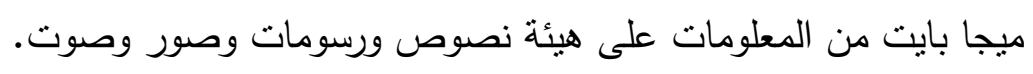

- - صغر حجمها وخفة وزنها وقدرتها المثالية لنقل المعلومات بالإضافة إلى متانتها وسهولة حفظها في غلاف لحمايتها من البصمات والخش فلا تتأثر عند قراءتها

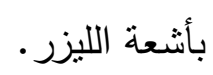
- عدم تأثرها بالمجالات المغناطيسية العادية أو أثعة أكس (X-Ray) - - انخفاض ثمنها مقارنة بالوسائل التقليدية لتخزين وعرض المعلومات. 
- - يمكن سماعها مرات متعددة, وهذا التكرار يساعد على تتبيت المعلومات والأفكار في

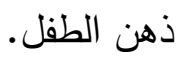

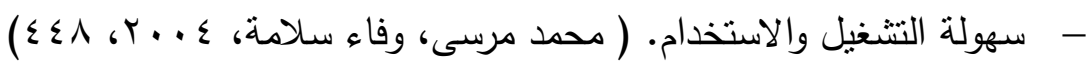
وترى الباحثة أنه من مميزات القصص الإكترونية إنه يمكن للطفل أن بستخدمها في أي

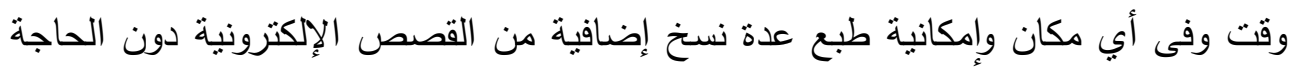
إلى أجزة خاصة أو غالية الثمن.

\section{مواصفات قصص الأطفال الإلكترونية التعليمية ومعايير جودتها:}

للقصص الإلكترونية مواصفات ومعايير لابد أن تتميز بها وهى كما ذكرها

(Lambert , 2010)

- أن يتم برمجتها في إطار المتعة والتشويق من حيث الحركة والصوت والحوار

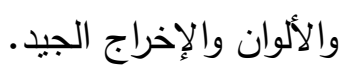

- - أن تتضمن القصة الإكترونية المبرمجة مواقف وأفكاراً تشد انتباه الطفل. - - أن تكون القصة الإكترونية سهلة الأسلوب في كلماتها وعبارتها حتى يتمكن الطفل

$$
\text { من فهمها وتتبع أحداثها. }
$$

- أن تكون القصة الإكترونية قصيرة بحيث لا يمل الطفل من الاستماع إليها

$$
\text { ومشاهدتها حتى النهاية. }
$$

- - يجب ألا تتضمن القصة الإكترونية المواقف المزعجة والمخيفة والمثيرة للانفعالات الحادة كالتعذيب المؤلم، أو الظلم القاسي؛ لأن مثل هذه المواقف تؤثنر في تكوين

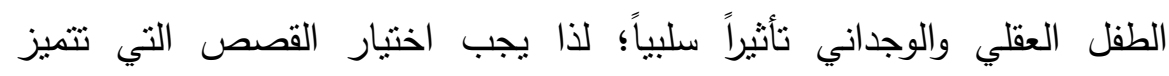
بانفعالات المرح والحب والعطف والابتهاج والتفاؤل.

- أن تشتمل على عدد مناسب من الصور والأصوات ولقطات الفيديو والنصوص

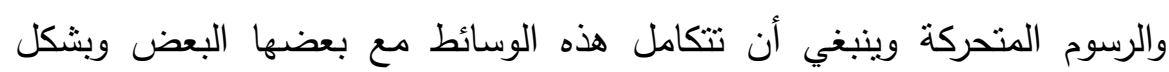
مناسب يسهم في تحقيق أهداف القصة. 
- أن يتوافر بها قدر من التوافق وإحساس المشاهد بالانسجام بين المكونات السمعية

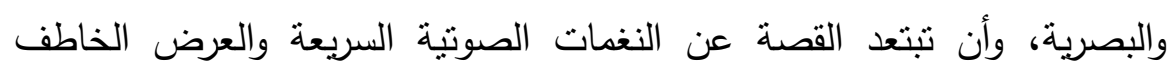
لل للصور

- - يتم فيها اختيار الحركة التي تجذب تركيز المشاهد لأحداث القصة، واختبار الصور التي يمكن أن تتقل المشاعر والعواطف وتؤكد وجهة نظر المشاهد. - أن تكون الخلفيات الموسيقية مناسبة، وتثير مشاعر وعواطف المشاهد نحو موضوع القصة. - تتضمن تعليقاً صوتياً لصاحب القصة،لأن ذلك يضيف مزيد من المصداقية والموضوعية، ويتم عمل بروفات قبل التسجيل النهائي للتعليق الصوتي، ويمكن

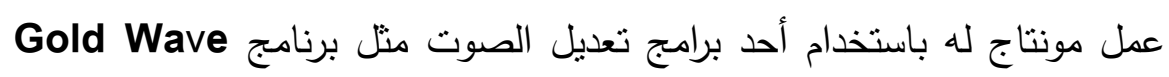
والذي يتيح إمكانية إجراء تعديلات على التعليق الصوتي والموسيقى. بلى بلئ.

أنواع القصص الإكترونية : Types of Digital Storis توجد عدة أنواع للقصص الإكترونية ويمكن توضيحها فيما يلي : - القصص التعليمية Instructional Stories: وإكساب الأطفال مفاهيم محددة، أو تدريبهر على ممارسة سلوكيات معينة، ومن ثم

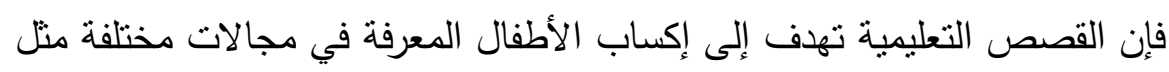
العلوم واللغة والرياضيات والتربية الصحية والبيئية وغيرها.

- القصص الثخصية Personal Stories: وهى قصص تحكى عن حكايات شخصية يمر بها أفراد، وهذا النوع من القصص له مميزات منها إنه يكسب

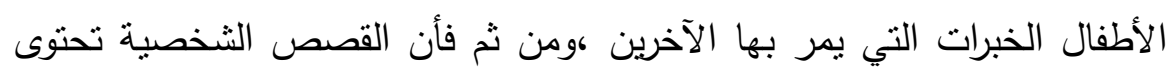

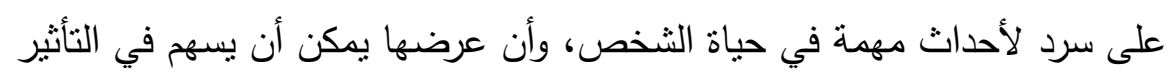
على حياة أشخاص آخرين. 
- القصص التاريخية Historical Stories: وهى القصص التي تحكى عن

$$
\text { أحداث تاريخية ومثيرة وتساعد الأطفال على فهم أحداث الماضى. }
$$

- القصص الوصفية Descriptive Stories: وهى قصص تعرض وصفاً للظواهر والقضايا والمشكلات من حيث الزمان والمكان والمكونات والمراحل الإجرائية التي تمر بها. (Lanir, 2012)، (Robin ,2008)

- - القصص الموجهة Directive Stories: وهى قصص صممت لتوجيه سلوكيات ومسارات الآخرين نحو اتجاهات معينة أو نماذج سلوكية مرغوبة أو قيم مطلوبة.

Elements of Digital Stories: عناصر القصة الإلكترونية اتفقت العديد من الدراسات والبحوث ومنها دراسة (Robin,2008)،ودراسة

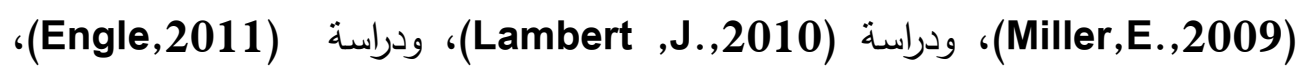

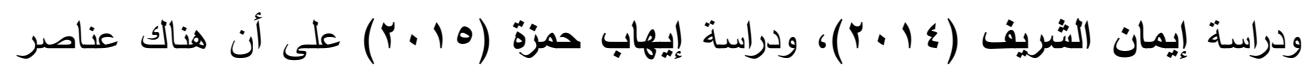
أساسية لبناء قصص إلكترونية شيقة وجذابة وفعالة قائمة على الوسائط المتعددة وينبغي مراعاتها عند تصميم القصص الإكترونية وهى: - الفكرة أو وجهة النظر(الاندماج الكلى للقصة) point of view: ينم حكاية القصة من أجل بناء وجهة نظر معينة حيث لا يتم حكاية القصة كمجرد حقائق بسيطة ويتم تحديد مختلف جوانب القصة بحيث يمكنها أن تخدم وجهة النظر هذهة ولنه مع وضع الجمهور والمشاهدين في الاعتبار وتوجيه وجهة النظر مباشرة لهم. - السؤال الدرامي أوالصراع Dramatic Question ويتم طرح هذا السؤال في بداية القصة، وذللك لجذب انتباه الطفل منذ البداية، ودعم هذا الانتباه أثناء المشاهدة أو الاستماع لإحداث القصة حتى النهاية، بحيث ينم الإجابة على هذاب لئه السؤال في نهاية القصة. - - المحتوى الوجداني أوالإنفعالى Emotional Centent :القصة الجيدة هي التي تخلق انفعالاً يشد الطفل حول أحداث الموقف منذ بداية القصة وحتى نهايتها، 
فالقصص التي تتعامل مع مواقف وجدانية مثل الثُعور بالحزن أو الفرح أو الثعور

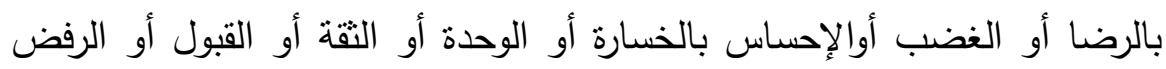

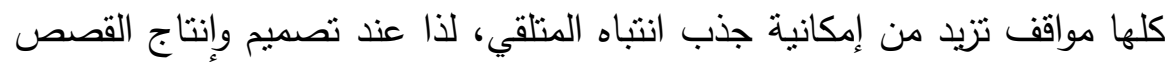
الإلكترونية لابد من التقكير في كيفية مخاطبة وجدان المتلقي، هذا بالإضافة إلى هرئ استخدام المؤثرات الصوتية والموسيقى ونبرات الصوت وكلها عناصر تؤثر في وجدان الطفل بشرط أن تتفق مع الحدث.

- موهبة صوت الراوي The Gift of Voce: الصوت موهبة عظيمة والبعض

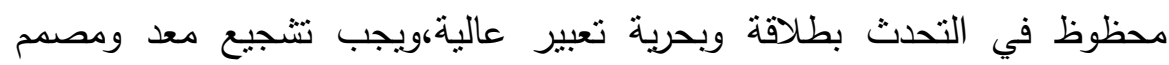
القصص الإكترونية على التعليق الصوتي على القصة بصوته، وأسهل طريقة لتحسين نسجيل الصوت بالقصص تسجيل الصوت عدة مرات متتالية واختبار أفضل المقاطع الصوتية المناسبة للقصة. - الموسيقى والمؤثرات الصوتية Sound Track: يختار البعض الموسيقى التصويرية للقصص الإكترونية وفقاً لحسهم وذوقهم الفني،والمؤثرات الصوتية والموسيقى المناسبة يمكنها أن تدعم الجانب الوجداني فيمكن تشغيل موسيقى الإنه

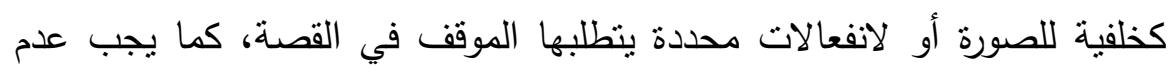
دعم استخدام مقطوعات موسيقية معروفة، وتقوم الموسيقى أيا كان نوعها بدور فعال، والجانب الأخر لاستخدام الصوت هو المؤثرات الصوتية وهى تضيف بعداً

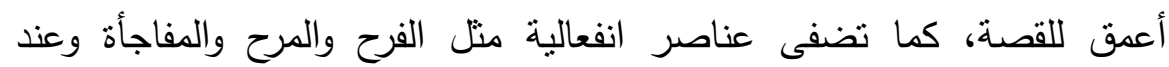
استخدام المقطوعات الموسيقية في القصص بمكن الاستعانة بمتخصصى الموسيقى، وهنالك بعض المكتبات الموسيقية الرقمية المتاحة والمجانية على شبكة الإنترنيت والتي يمكن الاستعانة بها.

- التلخيص: القصة الاكترونية الجيدة تكون قصيرة قدر الإمكان وتوضح وجهة نظر

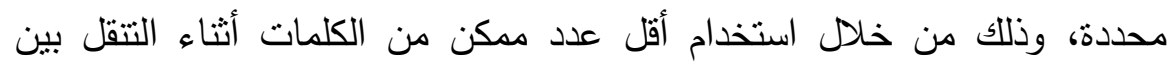

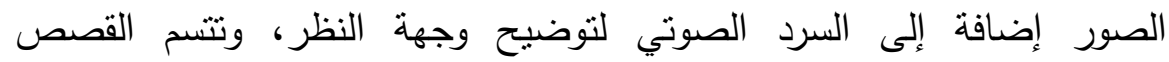
الإكترونية عن غيرها من القصص التقليدية بأنها يمكن توصيل المعلومات معرفياً 
ووجدانياً ليس فقط بقوة الكلمات ولكن بوسائط أخرى متعددة مثل الصوت والصورة والفيديو والنصوص.

- الاحترافية :القصة الإكترونية الجيدة تتضمن استخدام التكنولوجيا بشكل فني واحترافي يسمح للوسائط المتعددة والمؤثرات الصوتية بتوضيح الأحداث التي تدور لئهي

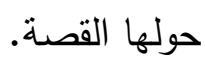
- - الخطو pace - السمة المميزة للقصة هو خطوها وإيقاعها وهو سر نجاحها، فايقاع

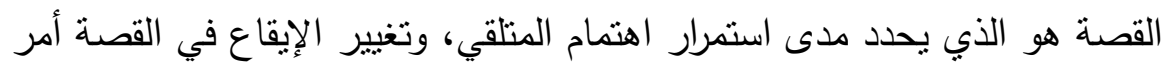
ضروري فالإيقاع الواحد أمر ينسبب في الفتور والملل. - الاقتصاد Economy :القصص الإلكترونية الجيدة والمؤثرة هي التي تستخدم المعلومات والصور والرسوم والأصوات اللازمة فقط لمحتوى القصة دون تحميل مشاهد القصة بمعلومات غير مطلوبة. خطوات كتابة القصة الإكترونية التعليمية: حدد بوفالا (Buvala,2009) عدة خطوات لكتابة القصة الإكترونية وهى: 1-اتخاذ قرار بإنتاج القصة الإكترونية: وذلك من حيث فكرتها، وموضوعها، وعنوانها.

r-تجزئة القصة إلى خطوط عريضة: من حيث الأحداث التي تمكن من تذكر عناصر القصة. r-كتابة القصة في نوتة: باستخدام الورقة والقلم الرصاص والبدء في كتابة ملخص لأحداث القصة.

ع - ارسم قصتك في ستورى بورد Story board منل الرسوم الفكاهية المرسومة باليد. ه- الحكى التجريبي للقصة: من خلال البدء في حكي القصة لنفسك بصوت عال وبكلماتك ومن خلال نوته القصة، مع تكرار ذلك ثلاث مرات في نوقيتات مختلفة. 
צ-التفكير العميق في القصة: من حيث هل توجد أجزاء يجب حذفها أو إضافتها، ثم

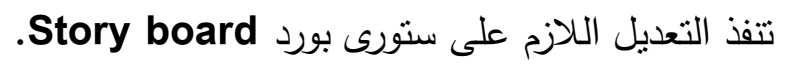
V-وضع الملاحظات على لوحة القصة المصورة: ثم أحك القصة لنفسك بصوت عال وبكلمانك وإيماءثلك.

^-حكي القصة على زميل: وذلك من خلال البحث عن صديق ثم حكي القصة عليه مع عدم استخدام النوتة.

9- إضافة المشاعر على القصة: وتأتى هذه المرحلة عندما تصل الثقة في القصة إلى إلى

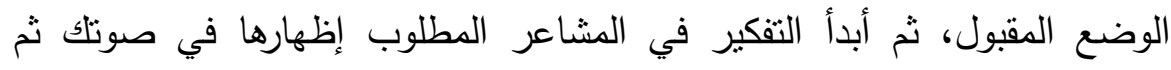
استخدم هذه المشاعر في سرد القصة.

مراحل تصميم وإنتاج القصة الإكترونية: phases of Designing \& Stories

\section{producing Digital}

بعد الإطلاع على العديد من الدراسات والبحوث السابقة العربية والأجنبية للتعرف

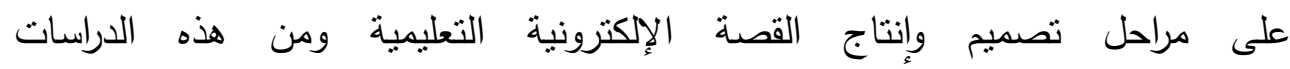
دراسة (Sadik,2008) ودراسة (Shung,2008) ودراسة (Lambert,2010) ودراسة (Compobell,2012) \& Rahimi,2017) ودراسة (Y.10) (Yadollahi

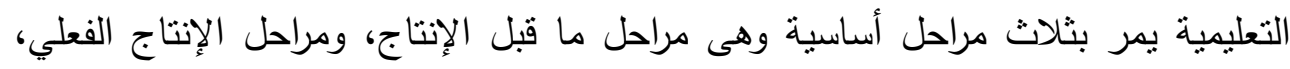

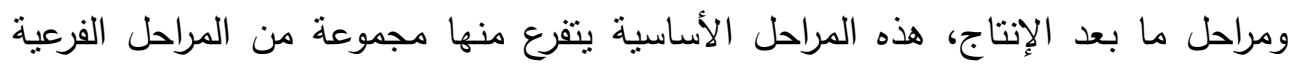
وفيما يلي عرض تفصيلي لتلك المراحل:

أولاً: مرحلة ما قبل الإنتاج Pre- Production Phase وتتقسم هذه المرحلة إلى ثناث مراحل فرعية وهى التخطيط، والتصميم، والإعداد وفيما يلى عرض لهذه المراحل : 
1 - مرحلة التخطيط: وفيها يتم تحديد الفئة المستهدفة التي ستقدم لها القصة الإلكترونية التعليمية ومن ثم تحديد خصائصها من حيث الخلفية المعرفية والخبرات ومستوى هنه

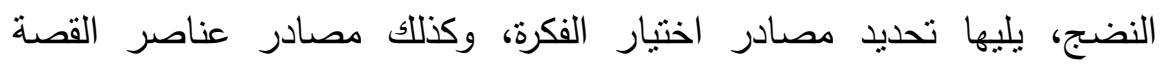

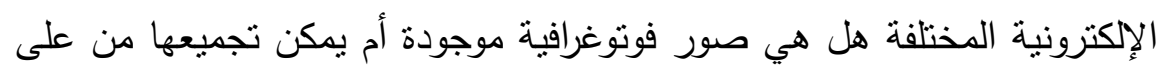
الثبكة أو إنتاجها بشكل رقمي، كذلك مقاطع الفيديو والموسيقى والتسجيلات الصوتية.

r- مرحلة التصميم: ويتم فيها تحديد الهدف العام من القصة وكتابة الأهداف الإجرائية القابلة للقياس، ويلي ذلك تجميع محتوى القصة.

ب- الإعداد: ويتم في هذه المرحلة إعداد لوحة القصة Preparing a storyboard وهى عبارة عن سيناريو مصور لجميع التفاصيل الخاصة بكل مشهد، توضح الترتيب الذي سنظهر به الثناثات فهي تحتوى على سلسلة من الرسوم توضح

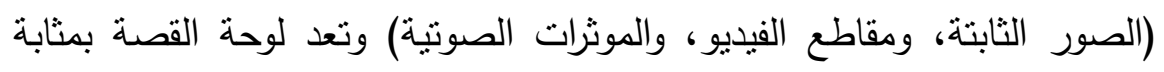

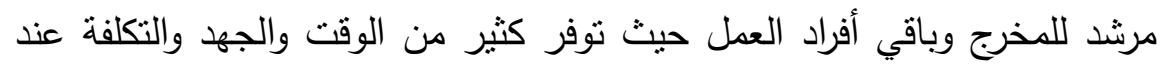
الإنتاج الفعلي للقصة.

ثانياً: مرحلة الإنتاج الفعلي Production Phase وهى المرحلة التي يتم فيها ترجمة السيناريو الصوتي والمصور إلى قصة إلكترونية وتمر مرحلة الإنتاج الفعلي بالمراحل الآتية :

1 - مرحلة التحديد، والتجميع،والتقرير: وفى هذه المرحلة يتم إنثاء مجلد على سطح

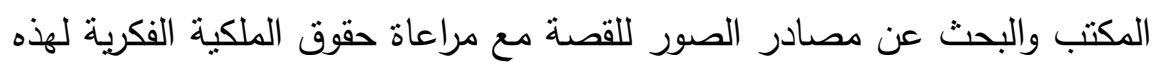

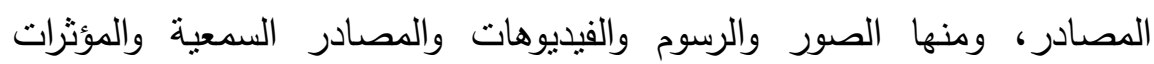
الصوتية وما إلى ذلك وحفظها في المجلد.

r- مرحلة الاختيار،والاستيراد، والإنشاء: وفيها يتم اختيار وتحديد البرنامج المستخدم

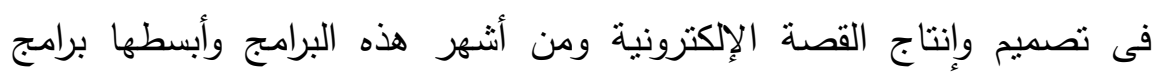
moviemaker 
باستخدام أحد البرامج، ثم استيراد العناصر التي تم إنتاجها إلى برامج إنتاج القصة، وإنشاء ملف القصة الإكترونية.

pots Production Phase ثالثاً: مرحلة ما بعد الإنتاج

بعد الإنتهاء من تجهيز القصة الإكترونية لابد من المرور بالخطوتين الآتيتين وهما :

1- التقويم: حيث يتم عرض القصة على خبراء متخصصين لتحديد نقاط القوة

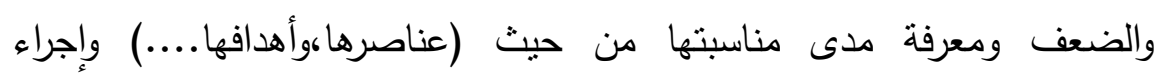

$$
\text { التعديلات المطلوبة. }
$$

r- النشر أو التوزيع: بعد الانتهاء من إجراء التعديلات على القصة المنتجة تتشر

$$
\text { على أقراص مدمجة أو شريط فيديو أو تتشر على مواقع الإنترنت. }
$$

وقد قامت الباحثة بإتباع تلك المراحل عند تدريب معلمات رياض الأطفال (عينة

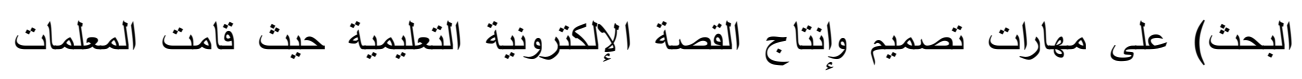
بتحديد محتوى القصص المقدمة لطفل الروضة وتحديد الهدف المرجو تحقيقه من كل قصة الهنة إلكترونية، كما تم تصميم القصص في ضوى ضوى المعايير التربوية الفنية والتقنية لإنتاج القصص الإلكترونية ومراعاة المعايير الخاصة بعناصر البناء الفني للقصص وإعداد سيناريو

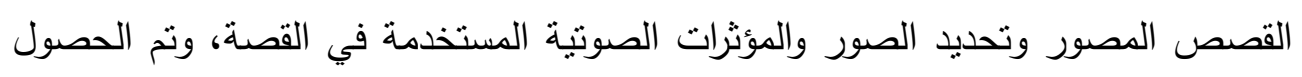
على الوسائط المتعددة من الصور والصوت، والمرحلة الأخيرة إنتاج القصة الإلكترونية

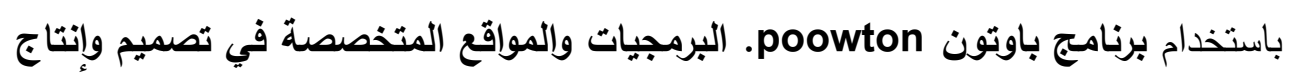

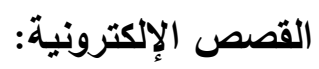

هناك العديد من البرمجيات والمواقع المجانية المتخصصة في تصميم وإنتاج القصص الإلكترونية ونظويرها، وهى من أفضل البرامج المتاحة على شبكة الإنترنت والتي لئي

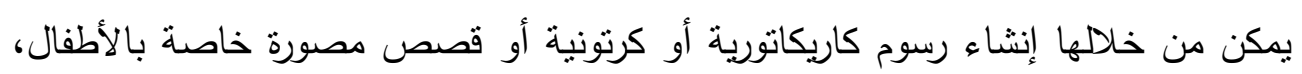

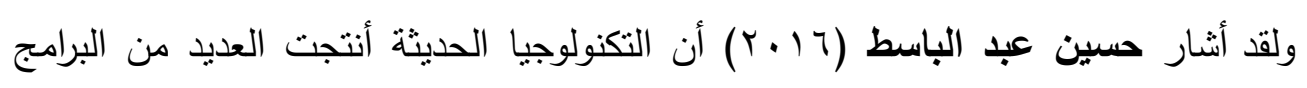
المتخصصة في تصميم القصص الإكترونية ووصف لكيفية استخدام هذه البرمجيات وكيفية الحصول عليها والمتطلبات اللازمة لاستخدامها في تصميم وإنتاج القصص الإكترونية، 
وتستخدم هذه البرمجيات وفق أجهزة الكمبيوتز وإمكاناتها ووفق المكونات والمصادر الرقمية المتاحة لاى القائم على تصميم وإنتاج القصص الإككترونية، وفيما يلي أهم هذه البرمجيات ولئي ووصف لكيفية الحصول عليها، والمتطلبات والمكونات اللازمة لاستخدامها في تصميم وإنتاج القصص الإكترونية وتطويرها.

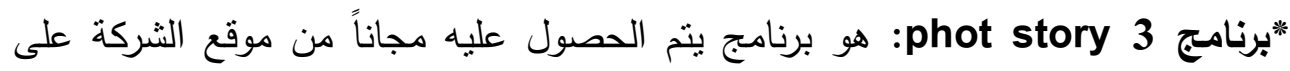
الإنترنت هو يعد برنامج للمتعلمين في جميع المراحل الدراسة لتصميم القصص الإكترونية من الصور والرسوم وتطويرها ويتميز بإمكانية إضافة نصوص ومؤثرات صوتية وخلفيات

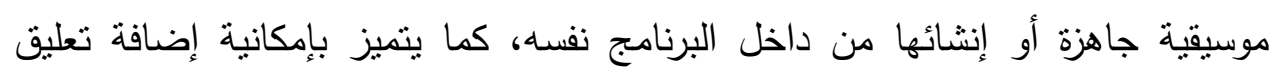

$$
\text { صوتي لصاحب القصة مع إمكانية خفض الصوت ورفعه. }
$$

"Windows Movie Maker وهو بعد برنامجاً مثالياً لجميع المراحل الدراسية لتصميم القصص الإكترونية وإعداد الصور الثابتة واللقطات وتطويرها، غير أنه لا يتيح

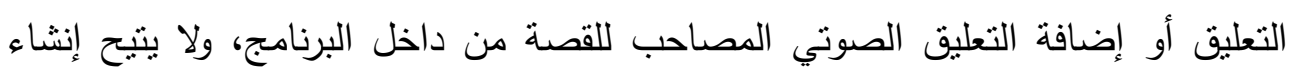

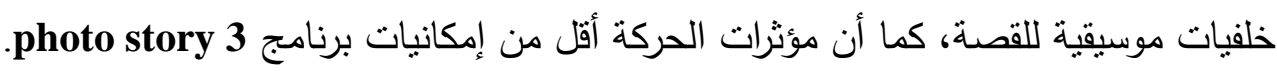

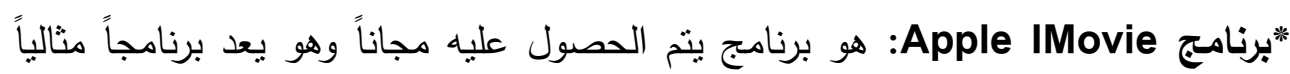

$$
\text { لتصميم القصص الإلكترونية وتطويرها. }
$$

*برنامج Adobe premiere: يتطلب استخدامه مهارات في مستوى المحترفين، الأمر الذي قد يصعب استخدامه مع المتعلمين في المراحل الدراسية المختلفة. "Power Point يتيح تصميم القصص الإلكترونية من الصور والرسوم الثابتة واللقطات المتحركة وتطويرها، غير إنه لا يتيح إمكانية نشر القصص المنتجة في صيغة ملفات الفيديو أو غيرها وتبقى على حالها في صيغة ملفات عروض ونيرهات تقديمية. Witty Comics * وخلفيات مرسومة مسبقاً. the popular Read Write Think خدمه يقدمها موقع:Comic Creator * الثهير وفى هذا البرنامج ما على المعلم إلا إنجاز المدخلات لكي يقوم هو بإنشاء الرسوم 
الكرتونية عبر مكتبة غنية بالخلفيات والثخصيات مع إمكانية طبع القصة عند الانتهاء من إعدادها.

"برنامج Pixton: وهو أداة رائعة يمكن استخدامها لإنشاء القصص المصورة والإلكترونية

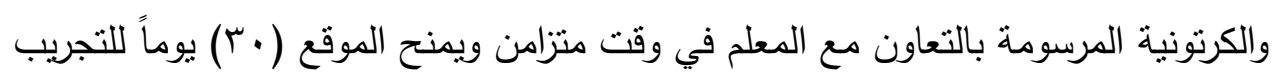
المجاني. "برنامج: Make Belief Comics يوفر هذا البرنامج شخصيات وأدوات مختلفة وخلفيات جاهزة تمكن مستخدميه من إبداع القصة الإلكترونية ومشاركتها مع الآخرين.

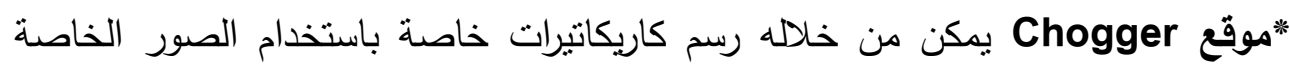
والموجودة على جهاز الكمبيوتر مع إمكانية الرسم بالأدوات المتاحة على الموقع.

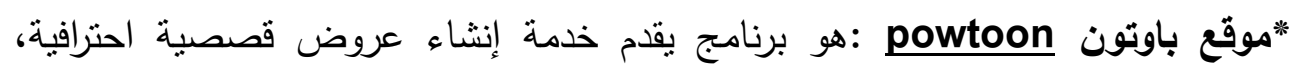

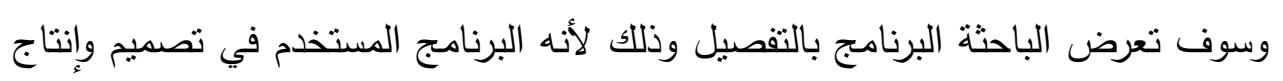

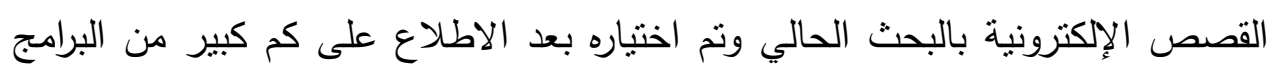

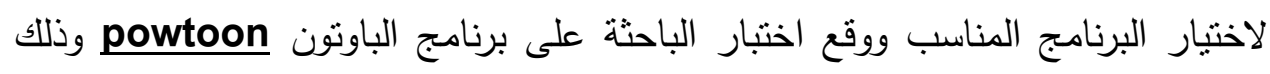

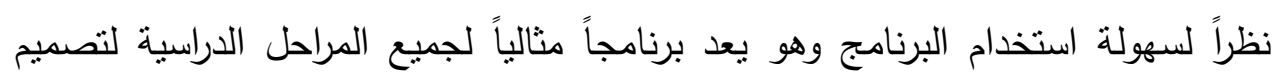

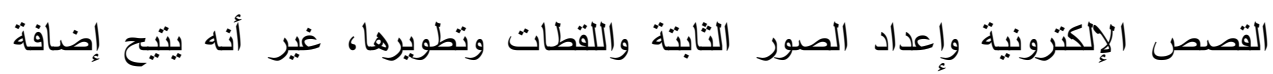
التعليق الصوتي المصاحب للقصة من داخل البرنامج، ويتيح إنثاء خلفيات موسيقية للقصة، هذا بالإضافة إلى إنه يتيح تصدير فيديو القصة إلى جميع وسائل التواصل الاجتماعي. التعريف ببرنامج powtoon :هو برنامج يقدم خدمة إنثاء عروض قصصية

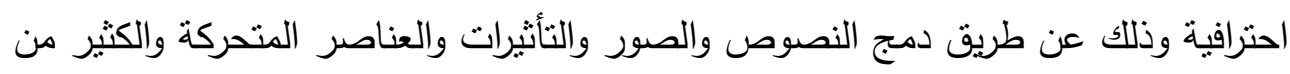

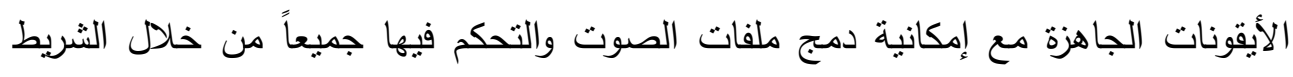
الزمني بسهولة بالغة، وبعد الانتهاء يمكن تصدير الفيديو إلى اليوتيوب أو يمكن مشاركته

$$
\text { في شبكات التواصل الاجتماعية. }
$$

مميزات استخدام برنامج الباوتون powtoon في تصميم وإنتاج القصص الإكترونية. - - إمكانية تقديم عرض مصور واحترافي في نفس الوقت. 
- - - إمكانية التسجيل بالموقع مجاناً.

- - مكانية عرض القصة بطريقة العرض التقديمي أو بطريقة فيديو .

- - مكانية نسجيل صوت وعرض كل شريحة بصوت ورسوم متحركة.

- - إمكانية استخدام القوالب الجاهزة وهي متعددة أو دمج أكثر من قالب أو تصميم القالب باختيارك.

- - يدعم البرنامج اللغة العربية في العروض التقديمية. - برنامج ممتع ومشوق لعرض المادة التعليمية بعيداً عن الطرق التقليدية.

عيوب استخدام برنامج الباوتون في إنتاج وتصميم القصص الإكترونية : - - مرورة الاتصال بالإنترنت. - في الحساب المجانيّ يجب ألا يتعدى الفيديو خمس دقائق. - القوالب الجاهزة لا تدعم اللغة العربية. - - يشغل المتدبين عن الثرح بسبب انشغالهن بالصور والرسومات المعروضة.

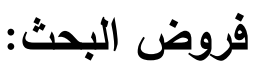

من خلال الإطار النظري والدراسات السابقة، فإن البحث الحالي يختبر صحة الفروض التالية :

1- توجد فروق ذات دلالة إحصائية بين متوسطي درجات معلمات رياض الأطفال (عينة البحث) في النطبيق القبلي للاختبار المعرفي ومتوسط درجاتهن في التطبيق البعدى لصالح التطبيق البعدى. 


\section{المجلة العلمية لكلية رياض الاطفال - جامعة اسيوط}

r - توجد فروق ذات دلالة إحصائية بين متوسطي درجات المعلمات (عينة البحث) في النطبيق القبلي لبطاقة ملاحظة مهارات ما قبل تصميم وإنتاج القصص الإككترونية ومتوسط درجاتهن في التطبيق البعدى لصالح التطبيق البعدى.

r- توجد فروق ذات دلالة إحصائية بين متوسطي درجات المعلمات (عينة البحث) في

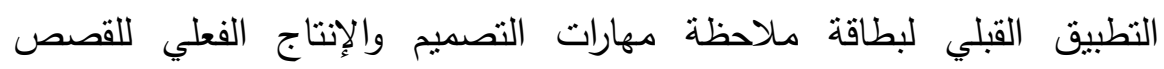
الإككترونية ومتوسط درجاتهن في التطبيق البعدى لصالح التطبيق البعدى.

ـ - توجد فروق ذات دلالة إحصائية بين متوسطي درجات المعلمات (عينة البحث) في التطبيق القبلي لبطاقة ملاحظة مهارات ما بعد تصميم وإنتاج القصص الإلكترونية ومتوسط درجاتهن في التطبيق البعدى لصالح التطبيق البعدى.

ه - نوجد فروق ذات دلالة إحصائية بين متوسطي درجات المعلمات (عينة البحث) طبقاً لبطاقة تقييم القصص الإكترونية التعليمية والقيمة المختبرة (درجة الإتقان التي تساوى •^\% من الدرجة الكلية لبطاقة تقييم القصص الإلكترونية) لصالح

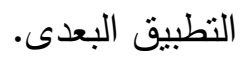

\section{إجراءات البحث:}

أولاً عينة البحث: أجري البحث على مجموعة من معلمات رياض الأطفال بروضات (مدرسة الرعاية المتكاملة، وروضة مدرسة الزاهراء، وروضة مدرسة طارق بن زياد

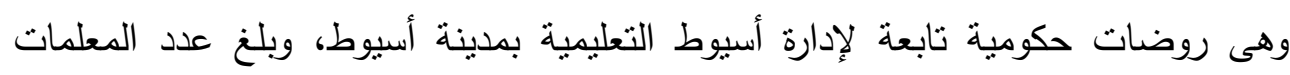

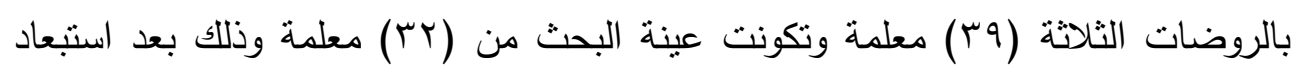
المعلمات غبر الراغبات في المشاركة بالبرنامج التدريبي نظراً لظروف خاصة لاصنة لديهن، واستبعاد المعلمات غير الملتزمات بحضور جلسات البرنامجهوتم تطبيق البرنامج التدريبي

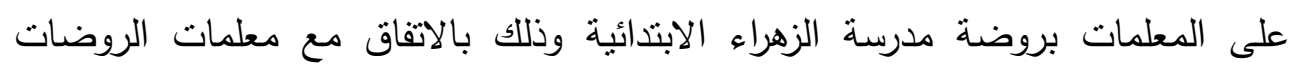

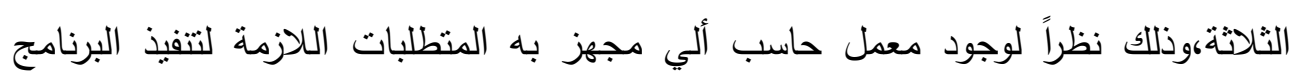

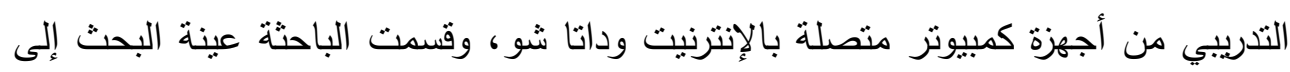

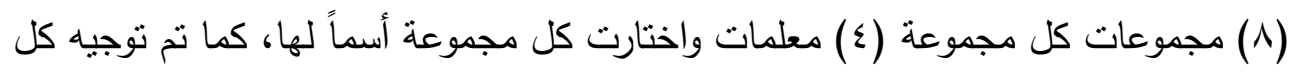


مجموعة لاختبار قائد لها ليقوم بتوزيع العمل بين أعضائها، وقد تم التقسيم إلى مجموعات حسب رغبة المعلمات أنفسهن وذلك لخلق فرصة للنألف فيما بينهن أثناء جلسات البرنامج التدريبي وورش العمل التي تقوم بها المعلمات لتصميم وإنتاج القصص الإكترونية . ثانياً أدوات ومواد البحث:

ا - قائمة بالمهارات الأساسية اللازمة لمعلمات رياض الأطفال لتصميم وإنتاج القصص

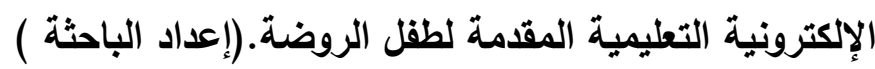
وفيما يلي الخطوات التي اتبعت في إعداد قائمة المهارات: الهُف من القائمة :هدفت القائمة إلى تحديد المهارات الأساسية اللازم نوافرها لدى معلمة رياض الأطفال لتصميم وإنتاج القصص الإكترونية التعليمية المقدمة لطفل الروضة. مصادر إعداد القائمة : استخلصت الباحثة المهارات الأساسية اللازمة لتصميم وإنتاج القصص الإكترونية المقدمة لطفل الروضة من مصادر متعددة ومنتوعة ويمكن تحديد تلك المصادر التي استندت عليها الباحثة في النقاط التالية:

- الاطلاع على الدراسات والبحوث السابقة التي تتاولت مهارات تصميم القصص بصفه عامة والقصص الإلكترونية بصفة خاصة ويعد هذا الدصدر من الدصادر الرئيسة لقائمة المهارات،ومن هذه الدراسات دراسة (Sadik,2008) ودراسة Compobell, 2012) ودراسة (Shung,2008)

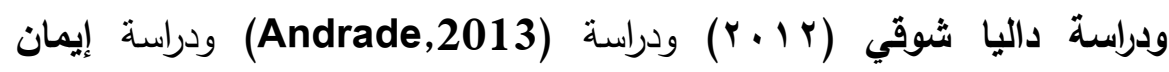

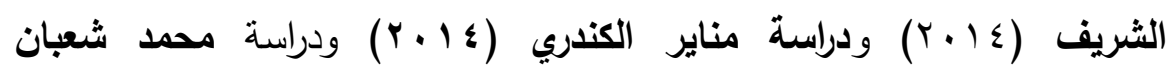

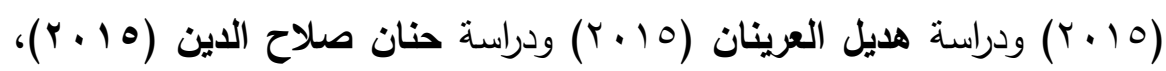

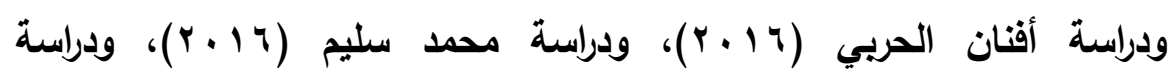
.(Jakes\&Brennan, 2015) 
- - المقابلات الثخصية التي أجرتها الباحثة مع المتخصصين في تكنولوجيا التعليم

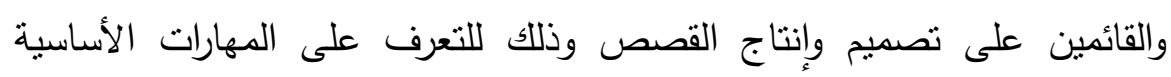
اللازمة لتصميم وإنتاج القصص الإلكترونية.

- - الإطلاع على قوائم المهارات التي أعدت لتصميم وإنتاج القصص الإكترونية. آراء الخبراء والمتخصصين في مجال تكنولوجيا التعليم وتعد هذه الآراء من المصادر التي لا يجب إهمالها عند بناء قائمة المهارات نظراً لخبراتهم وتجاربهم العملية في تصميم وإنتاج القصص الإلكترونية. الاستعانة بالإطار النظري في تحديد مهارات تصميم وإنتاج القصص الإلكترونية والمؤشرات الأدائية للمهارات.

• نتائج اسنطلاع الرأي الذي أجرته الباحثة على معلمات رياض الأطفال ملحق (1) (1)

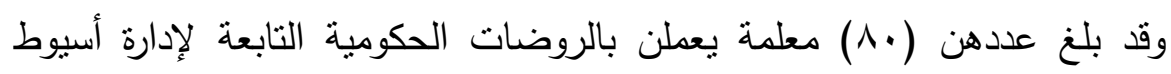

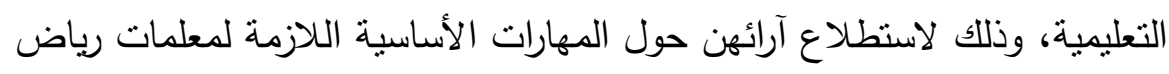

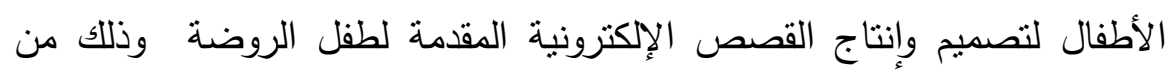

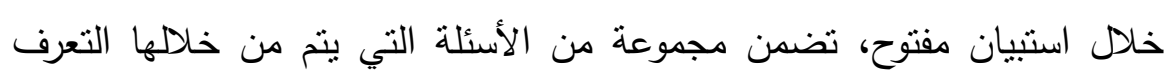

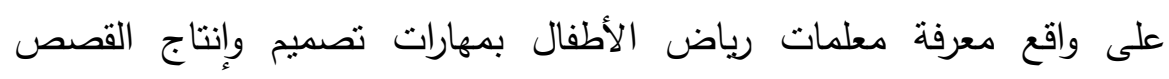

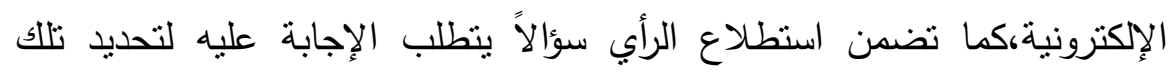

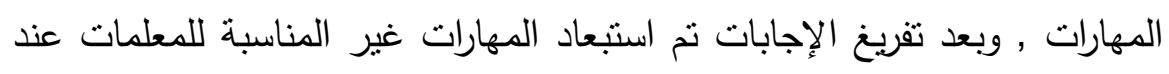
تصميم وإنتاج القصص الالكترونية.

ومن خلال النقاط السابقة تم التوصل إلى قائمة مبئية بالمهارات الأساسية اللازمة

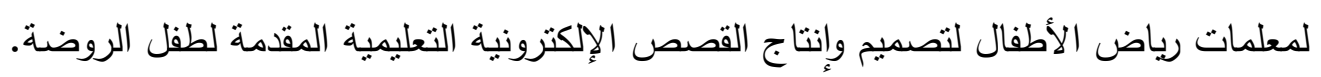
مكونات قائمة مهارات تصميم وإنتاج القصص الإكترونية التعليمية: من خلال المصادر السابقة تم وضع صورة مبدئية لقائمة المهارات الأساسية

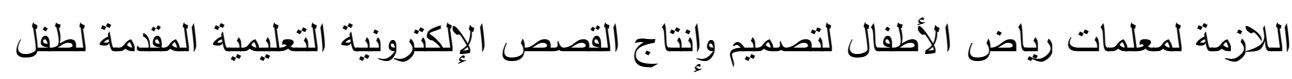
الروضة وقد تكونت القائمة من المهارات التالية: 
د/ منال محمود عبد الحميد موسى فاعلية برنامج تدريبى لمعلمات رياض الأطفال

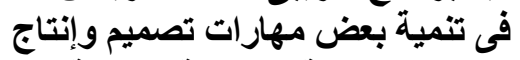
القصص الإكترونية التعليمية المقدمة لطقل الروضة

*مهارات ما قبل تصميم وإنتاج القصص الإكترونية واشتملت على المهارات الفرعية التالية :

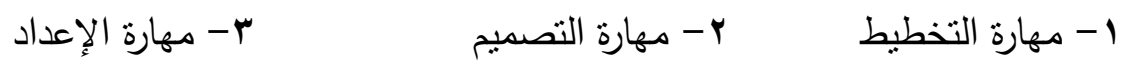

"مهارات التصميم والإنتاج الفعلي للقصص الإكترونية وإثتملت على المهارات الفرعية

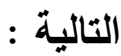

1- مهارة تجميع وتجهيز العناصر الخاصة بتصميم وإنتاج القصة الإكترونية. ץ - مهارة اختيار واستيراد وإنشاء العناصر المستخدمة في تصميم وإنتاج القصة الإلكترونية. r- مهارة الإنتاج الفعلي للقصة باستخدام البرنامج المناسب.

*مهارات ما بعد تصميم وإنتاج القصص الإكترونية واشتملت على المهارات الفرعية التالية : r - مهارة النشر والنطوير 1- مهارة الثقوبم

كما تضمنت قائمة المهارات مقدمة توضح للسادة المحكمين، الهدف من إعداد

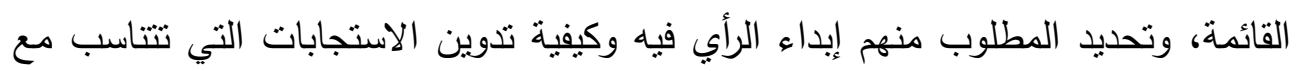
ارائهم.

تحكيم القائمة: بعد التوصل إلى قائمة المهارات في صورتها الأولية تم عرضها على مجموعة من الخبراء والمتخصصين في المناهج وطرق التدريس وتربية الطفل

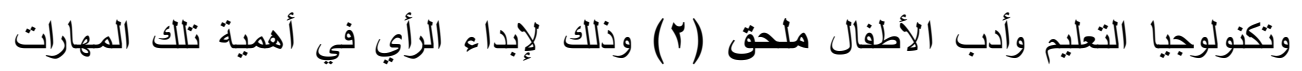

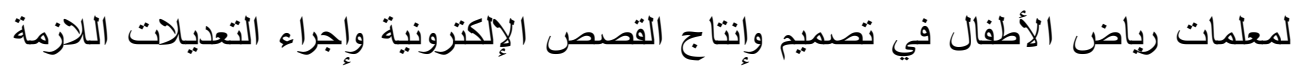
وفق ما يرونه من حيث ما يلي:

- ما ما ورد بالقائمة من مهارات أساسية وأخرى فرعية.

- مدى أهمية تلك المهارات لمعلمات رياض الأطفال في تصميم وإنتاج القصص الإلكترونية. 
- مدى ارتباط كل مهارة فرعية بالمهارة الرئيسية التي تتنمي إليها - - التأكد من الدقة العلمية والصياغة اللغوية للمهارات الواردة في القائمة. - - إعادة صياغة أية عبارات ترون إعادة صياغنها أو تعديل تركيبها اللغوى. - - إضافة أو حذف أو استبدال ما يرون إضافته أو حذفه أو استبداله من قائمة المهارات.

\section{تعديل القائمة وفقا لنتائج التحكيم:}

أولاً: بالنسبة للمهارات الأساسية: لم ينم حذف أي مهارة منها حيث أجمع المحكمون على كلى كلى

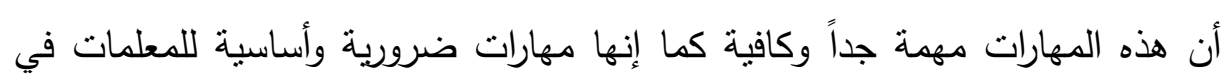

$$
\text { تصميم وإنتاج القصص الإلكترونية. }
$$

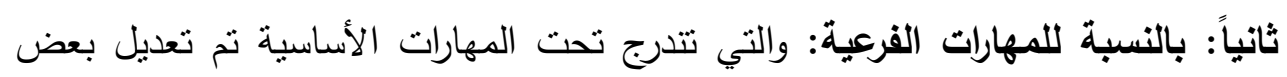

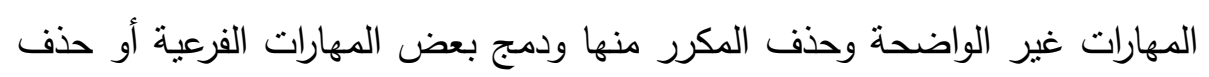

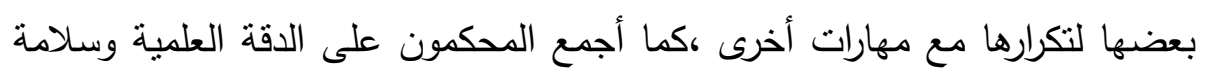

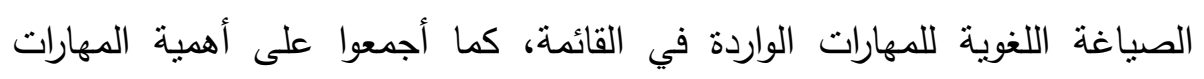

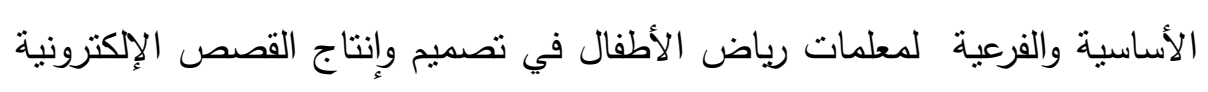
لطفل الروضة.

\section{صياغة القائمة في صورتها النهائية :}

بعد إجراء التعديلات التي أتفق عليها المحكمين أصبحت قائمة المهارات في

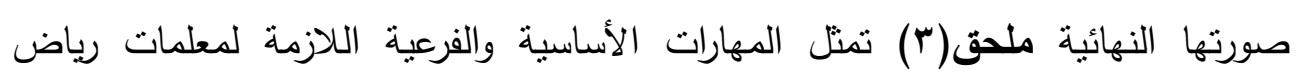
الأطفال لتصميم وإنتاج القصص الإلكترونية التعليمية المقدمة لطفل الروضة. ومن خلال هذا العرض لإجراءات تحديد المهارات الأساسية اللازم توافرها لدى

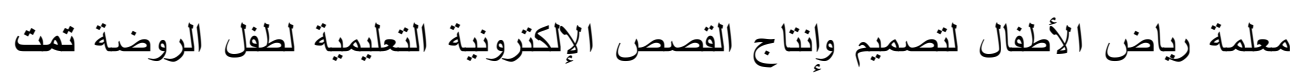
الإجابة عن السؤال الأول والثثاني من أسئلة البحث. 
r-قائمة المعايير التريوية والفنية والتقتية التي يتم في ضوئها تصميم وإنتاج القصص الإكترونية التعليمية المقدمة لطقل الروضة.

وفيما يلي الخطوات التي اتبعت في إعداد قائمة المعايير: الههف من قائمة المعايير :

هدفت القائمة إلى تحديد المعايير التربوية والفنية والتقنية التي يتم في ضوئها تصميم القصص الإكترونية ومؤشرات قياسها وترجمتها إلى محتوى علمي يستفاد منه في

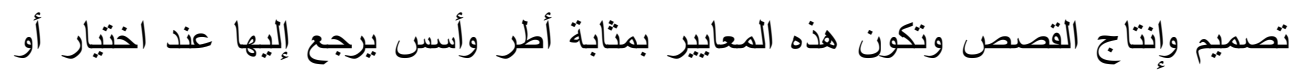
تصميم أو تقويم القصص الإلكترونية المقدمة لطفل الروضة. مصادر اشتقاق المعايير التربوية والقنية والتقنية التي يتم في ضوئها تصميم وإنتاج

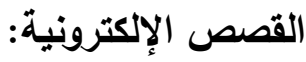

استخلصت الباحثة المعايير التربوية والفنية والتقنية اللازمة لتصميم القصص الإكترونية التعليمية المقدمة لطفل الروضة من مصادر متعددة ومتتوعة ويمكن تحديد تللك المصادر التي استتدت عليها الباحثة في الأتي:

- - أهداف مرحلة رياض الأطفال وخصائص النمو واحتباجات ومنطلبات هذه المرحلة. - الاطلاع على الدراسات والبحوث السابقة العربية والأجنبية التي تتاولت المعايير المستخدمة في اختيار وتصميم القصص القصص الإلكترونية ويعد هذا المصدر

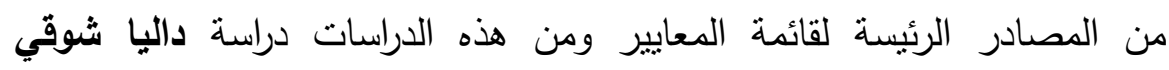

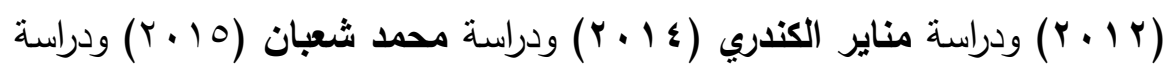

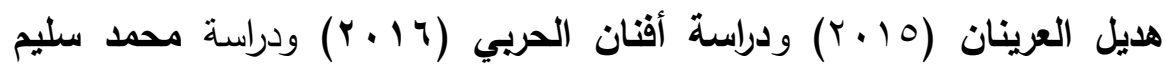
$\cdot(r \cdot 17)$ - المقابلات الثخصية التي أجرتها الباحثة مع المتخصصين في تربية الطفل وأدب الأطفال وتكنولوجيا التعليم وذلك للتعرف على المعايير التي يتم في ضونئها تصميم وإنتاج القصص الإكترونية المقدمة لطفل الروضة. 
*الإطلاع على قوائم المعايير التي أعدت لاختيار أو تقييم أو تصميم وإنتاج القصص بصفة عامة والقصص الإكترونية بصفة خاصة.

آراء الخبراء والمتخصصين وتعد هذه الآراء من المصادر التي لا يجب إهمالها عند

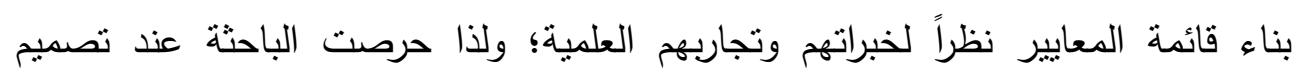

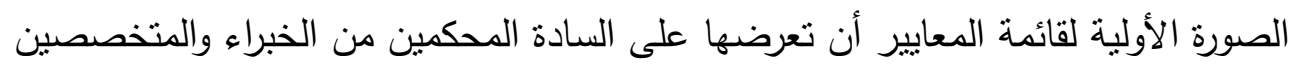

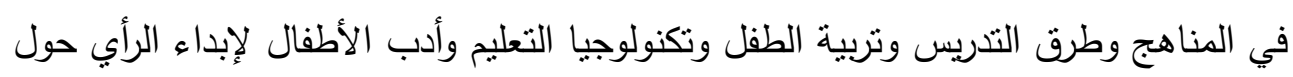

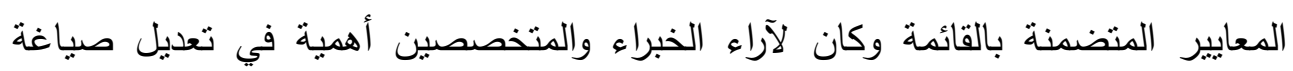
بعض المعايير وحذف بعضها وإضافة البعض الأخر. الصورة الأولية لقائمة المعايير:

من خلال الدصادر السابقة تم النوصل لصورة مبدئية لقائمة المعايير والتي ينم

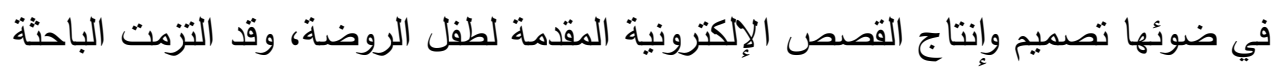

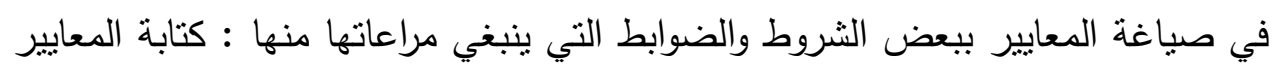
بلغة واضحة وخالية من الغوض بسيطة، ليسهل فهمها مختصرة وخالية من الآراء

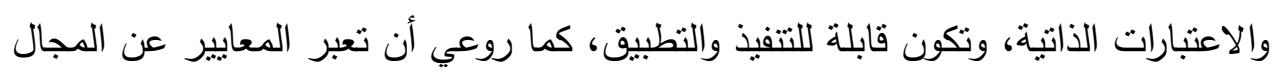

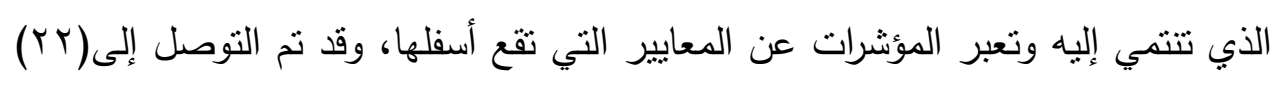

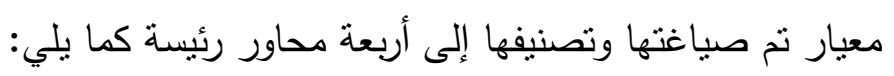

- المحور الأول المعايير التريوية لتصميم وإنتاج القصص الإكترونية: وتضمن هذا لفائ

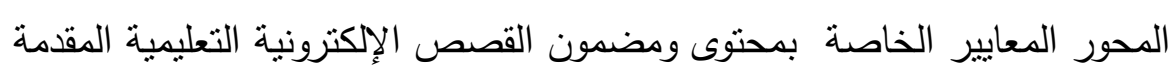
لطفل الروضة.

- المحور الثاني المعايير الخاصة بعناصر البناء الفني للقصة الإكترونية: وتثمل

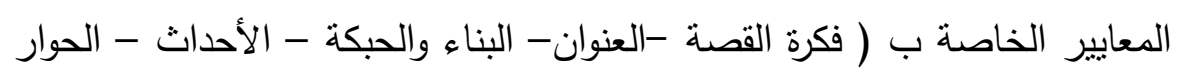

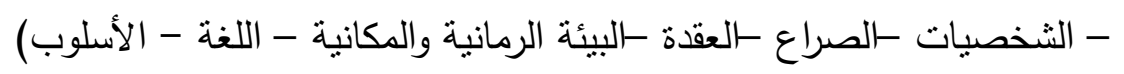

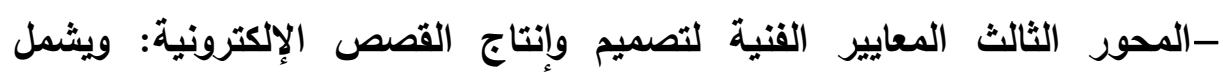
المعايير الفنية الخاصة بتصميم (الصور والرسوم الثابتة - المعايير الخاصة النئنة 
بتصميم الرسوم المتحركة - المعايير الفنية للقطات الفيديو - المعايير الفنية الخاصة بألوان القصة - المعايير الفنية الخاصة بالصوت وبالموسيقى والمؤثرات الصوتيةوالمعايير الفنية الخاصة بالنصوص المكتوبة بالقصة)

-المحور الرابع المعايير التقتية لتصميم وإنتاج القصص الإكترونية: وتثنمل المعايير الخاصة ب (استخدام وتتغيل القصة الإلكترونية - معايير خاصة بتصميم شاثات القصة الإكترونية- ومعايير خاصة بتحكم الطفل في القصة

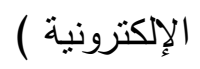

كما اشتمل كل معيار على عدد من المؤشرات في شكل عبارات واضحة ودقيقة تصف بطريقة إجرائية الأداء المطلوب، كما تضمنت قائمة المعايير مقدمة توضح الهدف منها وتوضح التعليمات للسادة المحكمين وتحديد المطلوب منهم إبداء الرأي فيه وكيفية تدوين الاستجابات التي تتتاسب مع أرائهم. تحكيم قائمة المعايير :

في ضوء ما سبق تم التوصل إلى الصورة المبدئية لقائمة المعايير التربوية والفنية والثقنية التي يتم في ضوئها تصميم وإنتاج القصص الإككترونية المقدمة لطفل الروضة ونم عرضها على عدد من المتخصصين في المناهج وطرق التدريس وتربية الطفل وتكنولوجيا

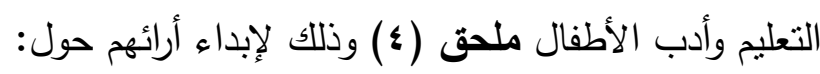

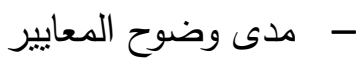
- مدى ارتباط كل مؤشر بالمعيار الفرعي الذي ينتمي إليه. - - مدى أهمية تلك المعايير والمؤشرات لمعلمات رياض الأطفال فى تصميم وإنتاج القصص الإلكترونية. - - التأكد من السلامة العلمية والصباغة اللغوية للمعايير والموشرات الواردة بقائمة المعايير • - - إضافة أو حذف أو استبدال ما برونه مناسباً من قائمة المعايير . 
نتائج تحكيم قائمة المعايير: أجمع المحكمون على صلاحية القائمة بوجه عام وعلى أهمية ما جاء فيها من محاور ومعايير ومؤشرات وقد اتضح من تحليل استجابات

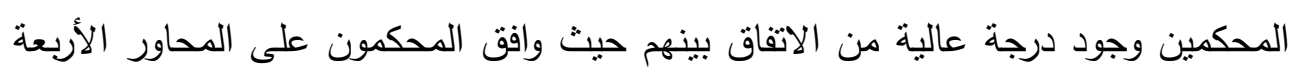
لقائمة المعايير بالإضافة إلى المعايير والمؤشرات الخاصة بكل محور وقد أجرت الجنة الباحثة التعديلات المطلوبة لتصبح قائمة المعايير في صورتها النهائية. تصحيح قائمة المعايير:

بعد عرض القائمة على مجموعة من المحكمين نم تفريغ استجابتهم وذلك بحساب

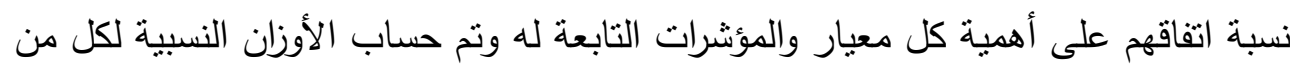

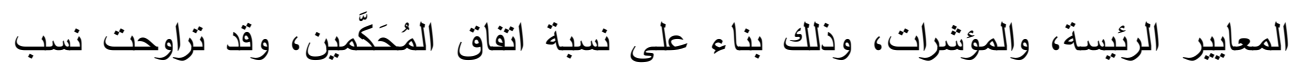
الاتفاق ما بين( •^، . . 1\% ) من إجمالي عدد المحكمين، وبالنسبة للمؤشرات الفرعية التي تندرج تحت المعايير الرئيسة نم تعديل صياغة بعض المؤشرات غير الواضحة، وكذلكاتل

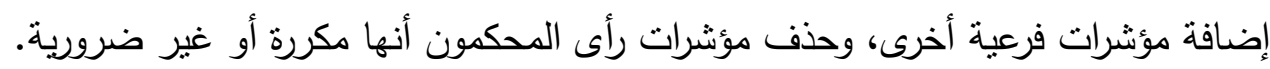

خلال النقاط السابقة تم التوصل إلى الصورة النهائية لقائمة المعايير التربوية والفنية والتقنية التي يتم في ضوئها تصميم وإنتاج القصص الإكترونية التعليمية المقدمة لطفل

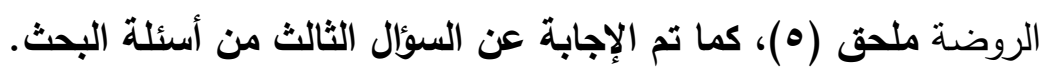
r-اختبار لقياس الجانب المعرفي لاى معلمات رياض الأطفال في تصميم وإنتاج القصص الإكترونية التعليمية المقدمة لطقل الروضة. (إعداد الباحثة) وفيما يلي الخطوات التي اتبعت في إعداد الاختبار :

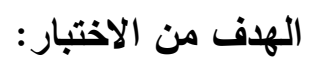

هدف الاختبار إلى قياس مدى اكتساب معلمات رياض الأطفال (عينة البحث)

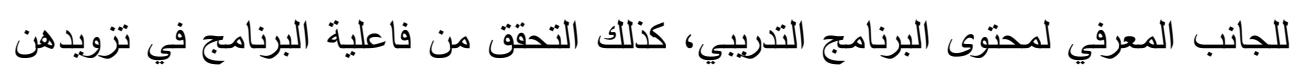

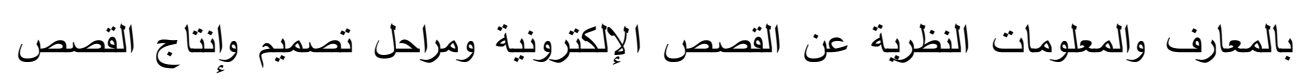
الإلكترونية التعليمية المقدمة لطفل الروضة. 
تم إعداد الاختبار في ضوء الإطار النظري، نم تحديد نوع أسئلة الاختبار من نوع الأسئلة الموضوعية حتى لا تتأثز بالعوامل الذاتية عند التصحيح، وذللك لتحقيق أكبر قدر من الموضوعية والثبات، ولسهولة التصحيح وقد راعت الباحثة عند صباغة أسئلة الاختبار

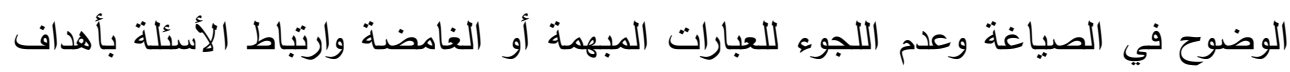
البرنامج، والتدرج في مستويات الأسئلة حتى تتاسب الفروق الفردية للمعلمات،أن تكون الأسئلة محددة وواضحة،تخلو من أي مؤشرات تدل على الإجابة،واستخدام مفردات لغوية

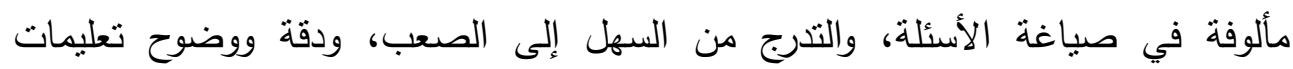

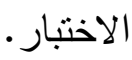

وتم صياغة أسئلة الاختبار بحيث تغطى موضوعات البرنامج وأهدافه وقد اختارت الباحثة من الأسئلة الموضوعية أسئلة الصواب والخطأ وعددها (· ب) سؤال، وأسئلة الاختيار

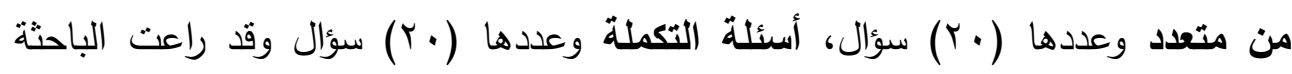

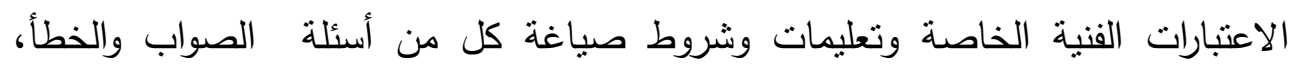
والاختبار من متعدد، وأسئلة التكملة، وبذلك يكون نم التوصل إلى الصورة المبئية للاختبار .

\section{تقدير درجات الاختبار وطريقة تصحيحه:}

بالنسبة لجميع أسئلة الاختبار تعطى المعلمة (درجة واحدة) لكل سؤال إذا كانت إجابتها صحيحة وتعطى (صفر) إذا كانت الإجابة خاطئة وذللك طبقاً لمفتاح التصحيح الخاص بالاختبار ملحق (†) وبذللك يكون مجموع درجات الاختبار ( • آ) درجة وهي الدرجة

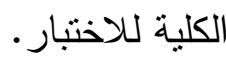

تعليمات الاختبار :تعد التعليمات من الجوانب المهمة في بناء الاختبار ،وقد تضمن

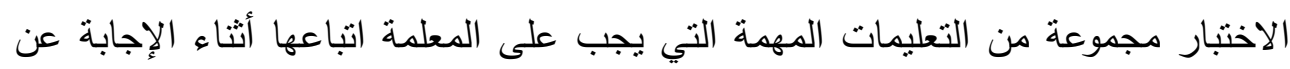

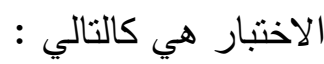
- الإجابة عن الأسئلة في ورقة الإجابة المنفصلة المعطاة لهن (النموذج المعد ل الإجابة). 
- عدم كتابة أب شئ في كراسة الإجابة المعطاة لهن. - - عدم البدء في الإجابة قبل الوقت المحدد لبدء الاختبار . - - الإجابة عن كل سؤال في المكان المحدد له في ورقة الإجابة المعطاة لهن.

$$
\text { - - يكون بدء الإجابة موحداً بعد قراءة التعليمات جيداً. }
$$

- - عدم وضع أكثر من علامة أمام السؤال الواحد في أسئلة الصواب والخطأ وأسئلة الاختيار من متعدد.

- - ملء المكان الخالي عند الإجابة على أسئلة التكملة بكلمة واحدة فقط. عرض الصورة الأولية الاختبار على المحكمين : بعد إعداد الصورة المبدئية للاختبار تم عرضه على مجموعة من المحكمين المتخصصين في المناهج وطرق التدريس وتكنولوجيا التعليم وأدب الأطفال ملحق( V) وذلك لمعرفة أرائهم في الاختبار وصياغة الأسئلة من ون

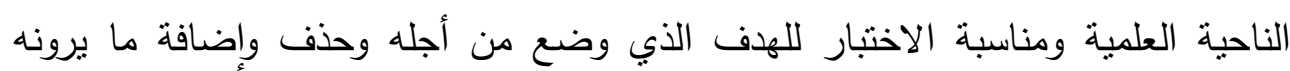

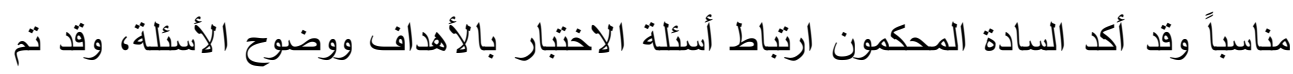

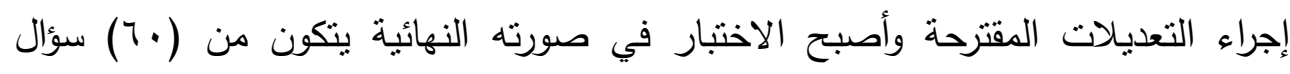
موزعة على أربعة أبعاد وهى كالتالي :

البعد الأول: التعرف على القصص الإكترونية ومفهومها وأهميتها وأنواعها وعناصرها، ومواصفاتها ومعايير جودتها ومميزات استخدامها وخطوات كتابتها، وعدد أسئلة

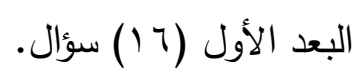

البعد الثاني: خطوات ومراحل تصميم وإنتاج القصص الإلكترونية ويتضمن (مراحل

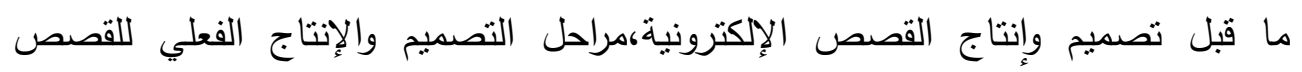
الإلكترونية،مراحل ما بعد تصميم وإنتاج القصص الإلكترونية ) وعدد أسئلة البعد الثاني

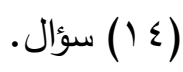


البعد الثالث: البرمجيات والمواقع المتخصصة في تصميم وإنتاج القصص ويتضمن التعريف بالمواقع والبرمجيات وإيجابيات كل موقع وسلبياته في تصميم القصص الإلكترونية، وعدد أسئلة البعد الثالث ( • () أسئلة.

البعد الرابع: برنامج الباوتون وهو البرنامج المستخدم في تصميم وإنتاج القصص القصله الإلكترونية في هذا البحث وتضمن التعريف بالبرنامج وخطوات استخدامه ومميزاته وعيوبه، وعدد أسئلة البعد الرابع (•r) سؤال.

الخصائص السيكومترية للاختبار:

بعد تصميم الاختبار فى صورتة النهائية، تم تطبيقه على عينة استطلاعية من المعلمات بلغ عددها (·r) معلمة يعملن بالروضات التابعة لإدارة أسيوط التعليمية بمدينة

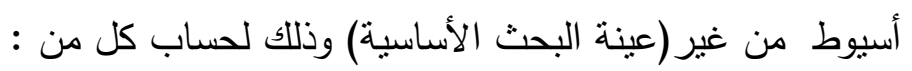

1- الصدق Validity: وقد استخدمت الباحثة الطرق التالية لحساب صدق الاختبار

• الصدق المنطقي (صدق المحكمين) Logical Validity بعرض الاختبار

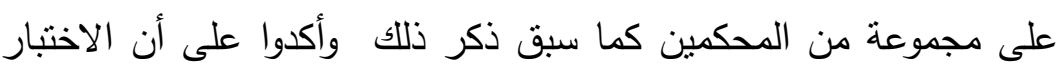
على درجة عالية من الصدق وأن الاختبار يقيس ما وضع لقئ لقياسه. الصدق التمييزى: تم حساب الصدق التمييزى للاختبار عن طريق حساب

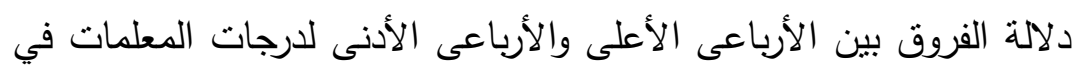

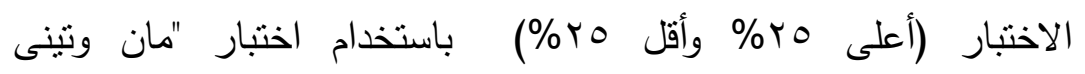

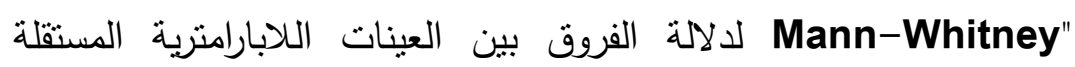
ويوضح الجدول التالي ذلك. 
جدول ( ) :متوسط ومجموع الرتب وقيمة (Z) ومستوى الدلالة للفرق بين الأرياعى الأعلى والأدنى لارجات المعلمات في الاختبار المعرفي

\begin{tabular}{|c|c|c|c|c|c|}
\hline مستوى الدلالة & قيمة Z & مجموع الرتب & متوسط الرتب & العداد & الأرياعيات \\
\hline \multirow[t]{2}{*}{$\ldots 1$} & \multirow[t]{2}{*}{ r.90 - } & 11 & $r .4$ & 。 & الأرياعى الأدنى \\
\hline & & Tr.O & Kr.o & 。 & الأرياعى الأعلى \\
\hline
\end{tabular}

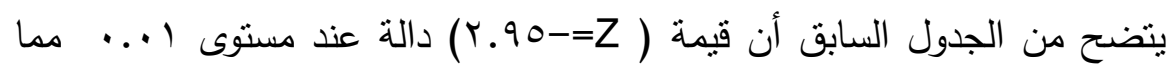
يؤكد ارتفاع الصدق التمبيزى للاختبار المعرفي.

r- الثبات Reliability : وقد تم حساب ثبات الاختبار بطريقتين وهما :

\section{: Alpha Cronbach Method طريقة ألفا كرونباك •}

استخدمت الباحثة معادلة ألفا كرونباك وهى معادلة تستخدم لإيضاح

المنطق العام لثبات الاختبارات والمقاييس، وبلغت قيمة معامل ثبات الاختبار r r . . وهى قيمة مرتفعة تدل على ثبات الاختبار ويوضح الجدول التالي معاملات ألفا كرونباك لأبعاد الاختبار . جدول (r):معاملات ألفا كرونباك لأبعاد الاختبار المعرفي

\begin{tabular}{|c|c|}
\hline معامل الثبات (ألفا كرونباك ) & أبعاد الاختبار المعرفي \\
\hline..$A r r$ & مفهوم القصص الإلكترونية وأهميتها وأنواعها وعناصرها \\
\hline$\cdots \cdot \wedge \leq 1$ & مراحل تصميم وإنتاج القصص الإلكترونية \\
\hline$\cdot . \wedge r$. & الإلكترونية \\
\hline$\therefore \wedge \leq 0$ & powtoon برنامج الباوتون \\
\hline 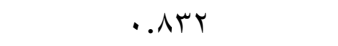 & الاختبار ككل \\
\hline
\end{tabular}

يتضح من الجدول السابق أن قيم معاملات الثبات باستخدام معادلة ألفا كرونباك

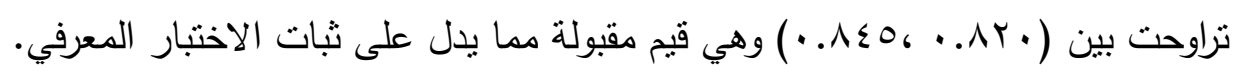


*التجزئة النصفية لأسئلة الاختبار :

للتأكد من ثبات الاختبار نم تجزئه فقراته إلى أسئلة فردية وأخرى زوجية وتم حساب معامل ارتباط بيرسون وتصحيح ذلك من خلال معاملي سبيرمان وجيتمان للتجزئة النصفية ويوضح الجدول التالي معاملات الارتباط

جدول (ץ):معاملات التجزئة النصفية للاختبار المعرفي

\begin{tabular}{|c|c|c|c|}
\hline الدلالة & معامل جتمان & معامل سبيرمان & الخواص الإحصائية \\
\hline$\ldots 1$ & . . $\vee \vee q$ & .1000 & الاختبار المعرفي \\
\hline
\end{tabular}

يتضح من الجدول السابق أن معاملات الارتباط دالة عند مستوى ا ... مما يدل على ثبات الاختبار وصلاحيته للاستخدام. r- معاملات السهولة والصعوية لمفردات الاختبار.

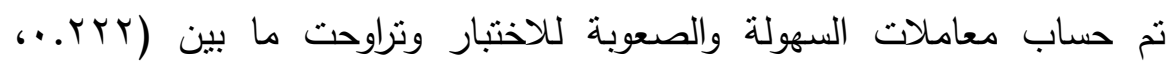

(^^. • ) ويوضح ملحق (^) معاملات السهولة والصعوبة لأسئلة الاختبار المعرفي. ع - زمن تطبيق الاختبار:

نم حساب زمن الاختبار الذي انتهى عنده 10\% من المعلمات من الإجابة عن

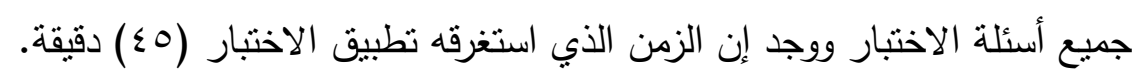

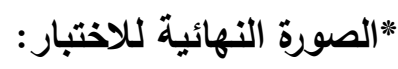

في ضوء الخطوات السابقة وبعد تعديل الاختبار وفقاً لآراء المحكمين وحساب

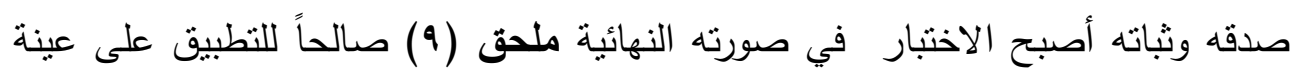
البحث الأساسية.

ع - بطاقة ملاحظة أداء معلمات رياض الأطفال لقياس الجانب الأدائي والمهاري لمهارات تصميم وإنتاج القصص الإكترونية المقدمة لطقل الروضة. (إعداد الباحثة ) وفيما يلي عرض للخطوات التي اتبعت أثناء إعداد بطاقة الملاحظة: 


\section{الهوف من إعداد بطاقة الملاحظة :}

هدفت بطاقة الملاحظة إلى قياس أداء معلمات رياض الأطفال في الجانب المهاري

لبعض مهارات تصميم وإنتاج القصص الإلكترونية التعليمية لطفل الروضة قبل وبعد التئل تلفيذ

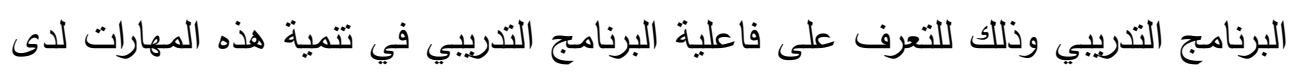
المعلمات،والتحقق من صحة الفروض الواردة بالبحث.

\section{مصادر تصميم بطاقة الملاحظة:}

من خلال معطيات الإطار النظري والدراسات والبحوث السابقة العربية والأجنبية التي اهتمت بالقصص الإكترونية تم تحديد المهارات الأساسية اللازمة لمعلمات رياض ولاض

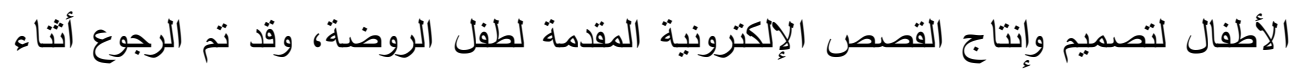
تصميم بطاقة الملاحظة إلى المصادر التالية:

- - الدراسات والبحوث التي تتاولت مهارات تصميم القصص بصفه عامة والقصص الإلكترونية بصفة خاصة.

- - الدراسات والبحوث المتخصصة في مجال تدريب معلمات رياض الأطفال والتي اهتمت ببناء بطاقة ملاحظة خاصة بمعلمات رياض الأطفال.

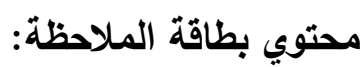

جاءت الصورة الأولية لبطاقة الملاحظة بنفس مكونات قائمة المهارات في صورتها النهائية مع اختلاف في التصميم فوضع أمام كل مهارة أدائية خانات تحدد مستوى أداء

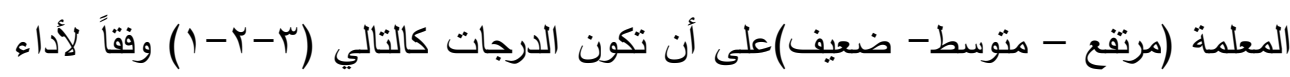
المعلمة وذلك بالإضافة إلى خانة الملاحظات، وهي منروكة للسادة المحكمين لإبداء آرائهم وملاحظاتهم في بطاقة الملاحظة التي أمامهم. وقد راعت الباحثة عند صياغة بنود بطاقة الملاحظة ما يلي : - أنثاء ملاحظتها. 
- - أن تكون الصباغة في شكل عبارات إجرائية، حيث تصف الأداء الفعلي المراد ملاحظته عند المعلمة.

- ل الخضع للتقييم أوالتفسير الذاتي من جانب أكثر من ملاحظ أو فاحص. - ـ كل عبارة تتضمن أداء واحد فقط.

- - أن تعبر كل عبارة عن إحدى المؤشرات التي ينم ممارستها وتكون تابعه للمجال

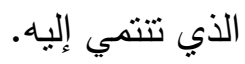

التقدير الكمي لأداء المعلمات في بطاقة الملاحظة :

تحسب درجة المعلمة في البطاقة بحساب مجموع درجات الأداءات التي قامت

بتنفيذها ومقارنتها بالدرجة الكلبة للبطاقة، وتدل الدرجة المرتفعة فى كل مهارة على ممارسة المعلمة للمهارة ممارسة فعالة، كما تدل الدرجة المنخفضة فى كل مهارة على عدم ممارسة

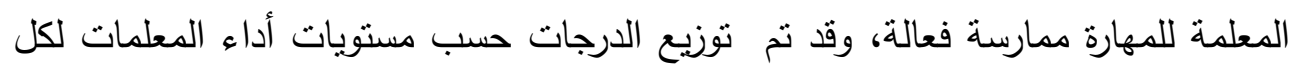
مهارة كالتالي : قامت بالأداء بمستوى مرتفع ثلاث درجات، قامت بات بالأداء بمستوى متوسط

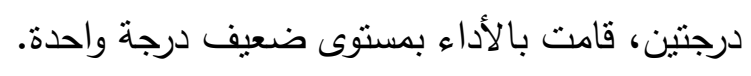

عرض بطاقة الملاحظة على المحكين: بعد إعداد الصورة المبدئية لبطاقة

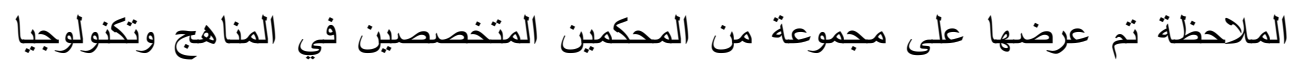

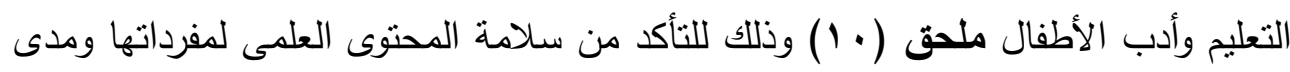

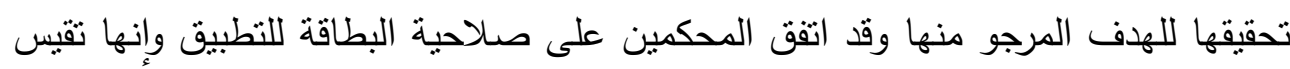
ما وضعت لقياسه،وبذلك ثم التوصل إلى الصورة النهائية لبطاقة الملاحظة.

\section{التجرية الاستطلاعية لبطاقة الملاحظة:}

بعد التوصل إلى الصورة النهائية لبطاقة الملاحظة نم تطبيقها على عينة

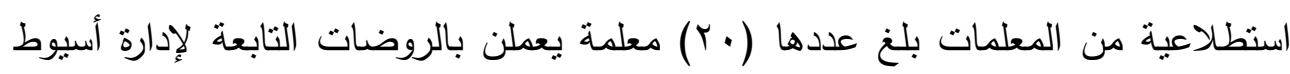

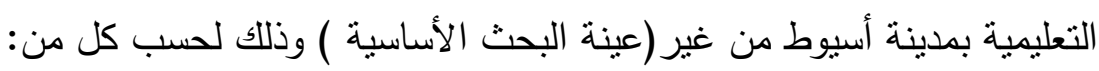
(1) الصدق Validity: وقد استخدمت الباحثة الطرق التالية لحساب الصدق وهى: 
Logical Validity (لصدق المنطقى (صدق المحكمين)" لكي تتحقق الباحثة من صدق البطاقة الملاحظة قامت بعرضها على مجموعة من

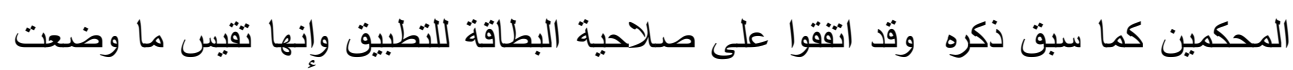
لقياسه. *الصدق التمييزى:

نم حساب الصدق التمييزى عن طريق حساب دلالة الفروق بين الأرباعى الأعلى

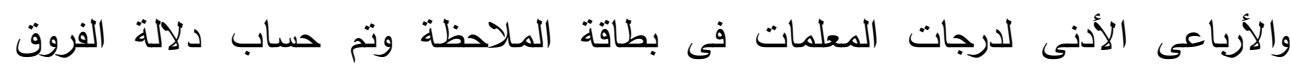

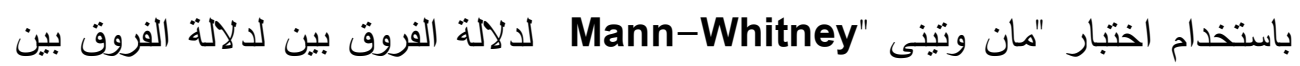

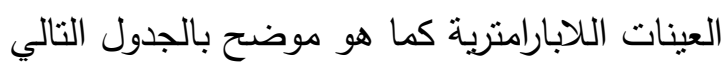

جدول ( ؛ ) :متوسط ومجموع الرتب وقيمة (Z) ومستوى الالالة للفرق بين الأرياعى الأعلى والأدنى لارجات المعلمات في بطاقة ملاحظة أداء معلمات رياض الأطفال لمهارات

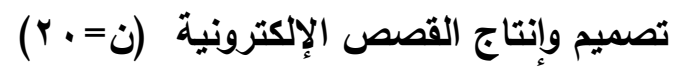

\begin{tabular}{|c|c|c|c|c|c|}
\hline مستوى الدلالة & قيمة Z & مجموع الرتب & متوسط الرتب & العدد & الأرياعيات \\
\hline \multirow[t]{2}{*}{$\ldots 1$} & \multirow[t]{2}{*}{ r.人T - } & 17 & T.乏 & 。 & الأرياعى الأدنى \\
\hline & & $r \varepsilon$ & $7 . \wedge$ & 0 & الأرباعى الأعلى \\
\hline
\end{tabular}

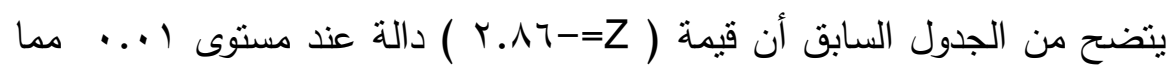
يؤكد ارتفاع الصدق التمييزى لبطاقة الملاحظة. (r) الثبات Reliability : وقد تم حساب ثبات بطاقة الملاحظة بطريقتين وهما : : Alpha Cronbach Method طريقة ألفا كرونباك" استخدمت الباحثة معادلة ألفا كرونباك وهى معادلة نستخدم لإيضاح المنطق العام

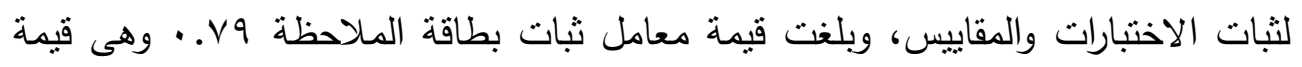
مرتفعة تدل على ثبات البطاقة ويوضح الجدول التالي معاملات ألفا كرونباك لأبعاد بطاقة بواته الملاحظة. 
د/ منال محمود عبد الحميد موسى

فاعلية برنامج تدريبى لمعلمات رياض الأطفال

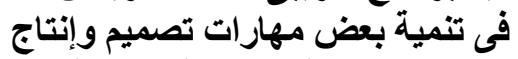

القصص الإكترونية التعليمية المقدمة لطقل الروضة

جدول (•):قيم معاملات ثبات بطاقة الملاحظة بطريقة ألفا كرونباك

\begin{tabular}{|c|c|}
\hline معامل الثبات (ألفا كرونباك) & أبعاد بطاقة الملاحظة \\
\hline$\cdot v \leqslant$ & مهارات ما قبل تصميم وإنتاج القصص الإلكترونية \\
\hline$\cdot . \wedge 1$ & مهارات التصميم والإنتاج الفعلي للقصص الإلكترونية \\
\hline$\cdot . \wedge \varepsilon$ & مهارات ما بعد تصميم وإنتاج القصص الإلكترونية \\
\hline.$\vee \vee 9$ & البطاقة ككل \\
\hline
\end{tabular}

يتضح من الجدول السابق أن قيم معاملات الثبات باستخدام معادلة ألفا كرونباك

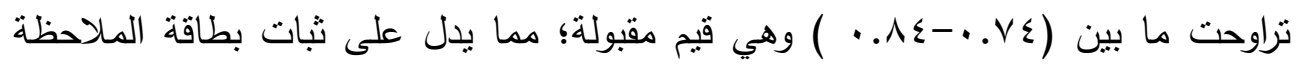
• وصلاحيتها للنطبيق

:التجزئة النصفية لفقرات البطاقة :

للتأكد من ثنات القائمة تم تجزئه فقراتها إلى أسئلة فردية وأخرى زوجية وتم حساب معامل ارتباط بيرسون وتصحيح ذلك من خلال معاملي سبيرمان وجتمان للتجزئة النصفية ويوضح الجدول التالى معاملات الارتباط.

جدول (؟) :قيم معاملات التجزئة النصفية لبطاقة ملاحظة أداء معلمات رياض الأطفال

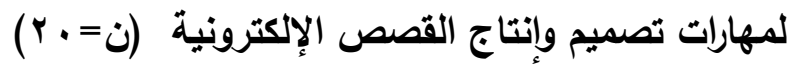

\begin{tabular}{|c|c|c|c|}
\hline الدلالة & معامل جتمان & معامل سبيرمان & الخواص الإحصائية \\
\hline$\ldots 1$ &..$A v V$ & אזה. & بطاقة الملاحظة \\
\hline
\end{tabular}

يتضح من الجدول السابق أن معاملات الارتباط دالة عند مستوى ا ... مما يدل على ثبات بطاقة الملاحظة وصلاحيتها للنطبيق.

فى ضوء الخطوات السابقة تم التوصل إلى الصورة النهائية لبطاقة الملاحظة

ملحق (11) وأصبحت جاهزة للنطبيق على المعلمات عينة البحث الأساسية. 
ه- بطاقة تقييم القصص الإكترونية التي تم تصميمها في ضوء المعاييز التريوية والفنية والتقتية لتصميم القصص الإكترونية التعليمية المقدمة لطقل الروضة.(إعداد

(الباحثة)

وفيما يلي عرض للخطوات التي اتبعت أثناء إعداد بطاقة تقييم القصص الإكترونية. الهوف من إعداد بطاقة تقييم القصص الإلكترونية : تهذف البطاقة تقبيم القصص الإلكترونية التعلبية التي قامت المعلمات بتصهيها وإنتاجها بعد عرض البرنامج التنريبي - على الدعلمات :مصادر إعداد بطاقة التقييم :

- الاطلاع على الدراسات والبحوث العربية والأجنبية التي تتاولت تقييم القصص

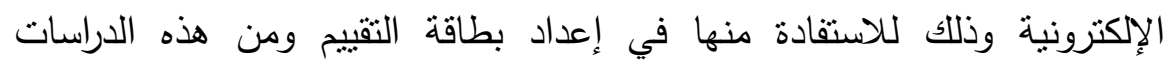

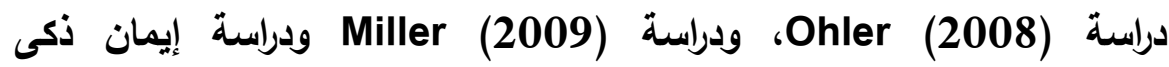

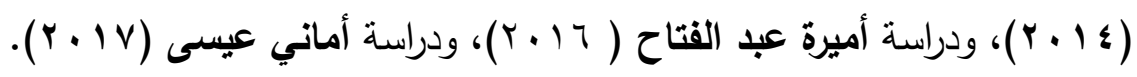
- تحديد محاور بطاقة التقييم بعد تحديد الهدف من بطاقة التقييم والإطلاع على مصادر إعدادها، حددت الباحثة محاور بطاقة التقييم ويشمل المحور الأول: المعايير التربوية الخاصة بتصميم وإنتاج القصص الإلكترونية، والمحور الثاني: المعايير الخاصة بعناصر البناء الفني للقصص الإلكترونية، والمحور الثالث: المعايير الفنية الخاصة بتصميم وإنتاج القصص الإكترونية، المحور الرابع: المعايير التقنية الخاصة بتصميم وإنتاج القصص الإككترونية وبلغ عدد البنود الكلية لبطاقة التقييم (VN) بنداً،وجاءت الصورة الأولية لبطاقة التقييم بنفس مكونات

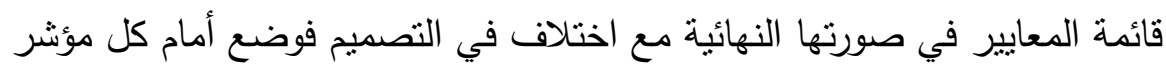

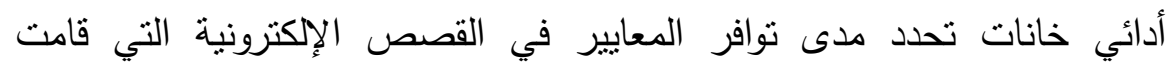

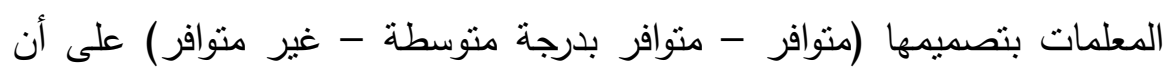

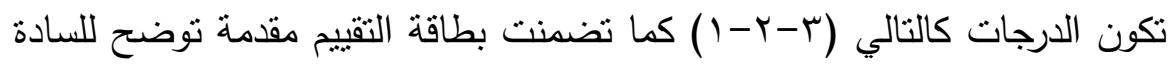
المحكمين الهدف منها والمطلوب منهم إبداء الرأي فيه. 
- عرض بطاقة تقييم القصص الإكترونية على المحكمين: بعد إعداد الصورة

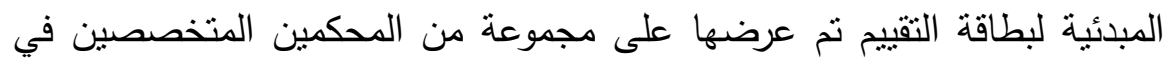

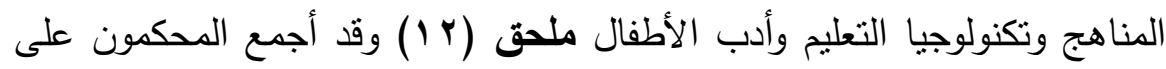
صلاحية بنود بطاقة تقييم القصص الإلكترونية وبذلك نم التوصل إلى الصورة النهائية لبطاقة تقييم تصميم وإنتاج القصص الإلكترونية.

التجربة الاستطلاعية لبطاقة التقييم:

بعد التوصل إلى الصورة النهائية لبطاقة تقييم القصص نم تطبيقهاعلى عينة

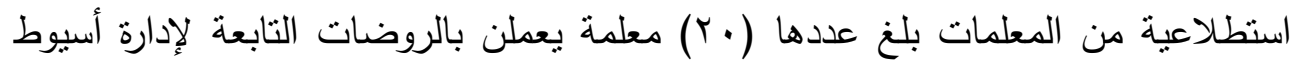

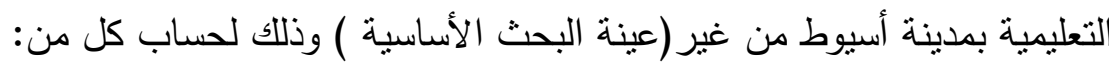
(1) الصدق Validity :وقد استخدمت الباحثة الطرق التالية لحساب الصدق وهى :

\section{Logical Validity الصدق المنطقى (صدق المحكمين)}

لكي تتحقق الباحثة من صدق بطاقة التقييم كما سبق ذكره قامت بعرضها على مجموعة من المحكمين المتخصصين وقد اتفق المحكمين على صلاحية البطاقة للتطبيق وإنها تقيس ما وضعت لقياسه، وبذللك تحققت الباحثة من صدق بطاقة التقييم.

• الصدق التمييزى : تم حساب الصدق التمييزى عن طريق حساب دلالة الفروق بين الأرباعى الأعلى والأرباعى الأدنى لدرجات المعلمات فى بطاقة التقييم (أعلى

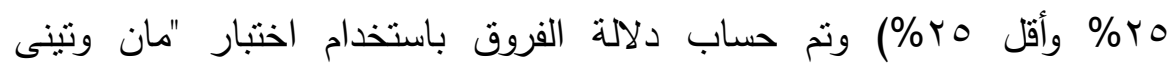

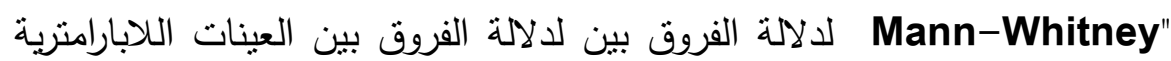
كما هو موضح بالجدول التالى 
المجلة العلمية لكلية رياض الاطفال - جامعة اسيوط

جدول (V):متوسط ومجموع الرتب وقيمة (Z) ومستوى الدلالة للفرق بين الأرباعى

الأعلى والأدنى لبطاقة تقييم القصص الإكترونية البهية

\begin{tabular}{|c|c|c|c|c|c|}
\hline مستوى الدلالة & قيمة Z & مجموع الرتب & متوسط الرتب & العدد & الأرباعيات \\
\hline \multirow[t]{2}{*}{$\ldots 1$} & \multirow[t]{2}{*}{ r.70- } & 10 & r... & 0 & الأرياعى الأدنى \\
\hline & & $\varepsilon$. & A... & 0 & الأرباعى الأعلى \\
\hline
\end{tabular}

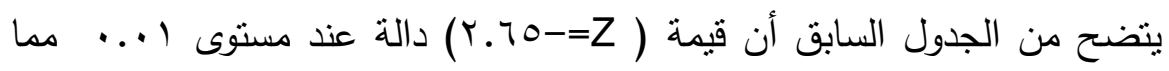

يؤكد ارتفاع الصدق التمبيزى لبطاقة تقييم القصص الإكترونية.

Reliability الثبات (Y) وقد تم بحساب ثبات بطاقة النقييم من خلال :

: Alpha Cronbach Method طريقة ألفا كرونباك"

استخدمت الباحثة معادلة ألفا كرونباك، وبلغت قيمة معامل ثبات بطاقة التقييم

ككل1،. . وهى قيمة مرتفعة تدل على ثبات البطاقة ويوضح الجدول التالي معاملات ألفا كرونباك لأبعاد بطاقة الثقييم.

جدول (^):قيم معاملات ثبات بطاقة تقييم القصص الإكترونية بطريقة ألفا كرونباك

\begin{tabular}{|c|c|}
\hline معامل الثبات (ألفا كرونباك) & أبعاد بطاقة تقييم القصص الإكترونية \\
\hline$\cdot . \wedge 9$ & المعايير التربوية الخاصة بتصميم وإنتاج القصص الإلكترونية \\
\hline$\cdot .9 \varepsilon$ & المعايير الخاصة بعناصر البناء الفني للقصص الإلكترونية \\
\hline .10 & المعايير الفنية الخاصة بتصميم وإنتاج القصص الإلكترونية \\
\hline-.91 & المعايير التقنية الخاصة بتصميم وإنتاج القصص الإكترونية \\
\hline. .19 & البطاقة ككل \\
\hline
\end{tabular}

يتضح من الجدول السابق أن قيم معاملات الثبات باستخدام معادلة ألفا كرونباك

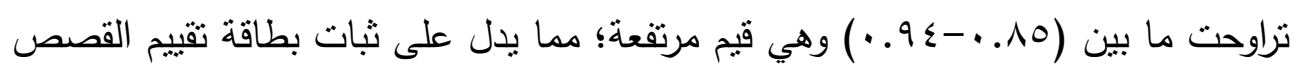
الإلكترونية وصلاحيتها للتطبيق.

وبذلك نم التوصل إلى الصورة النهائية لبطاقة تقييم القصص الإكترونية ملحق(T أ ) وأصبحت جاهزة للتطبيق. 
צ- برنامج تدريبي لمعلمات رياض الأطفال لتنمية بعض مهارات لتصميم وإنتاج القصص

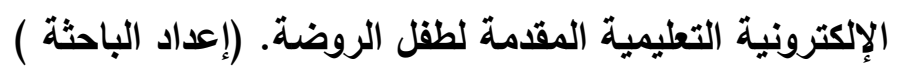

تم إعداد البرنامج التدريبي في ضوء ما ورد بالإطار النظري والإطلاع على البرامج التدريبية لمعلمات رياض الأطفال وفيما يلي عرض للخطوات المتبعة في إعداد البرنامج لئريج التدريبي على النحو التالي:

$$
\text { أهداف البرنامج التدريبي: }
$$

$$
\text { الهرف العام للبرنامج التدريبى: }
$$

يهاف البرنامج التدريبى إلى تتمية معارف ومهارات واتجاهات معلمات رياض الأطفال نحو مهارات تصميم وإنتاج القصص الإلكترونية التعليمية المقدمة لطفل الروضة. الأهداف الاجرائية للبرنامج التدريبى: بنهاية البرنامج التدريبى تكون المعلمة قادرة على أن : - - تتعرف على مفهوم القصص الإلكترونية. - ت تتعرف على الفرق بين القصة التقليدية والقصة الإكترونية. - تميز بين الأنواع المختلفة للقصص الإلكترونية. - - تعدد مميزات وخصائص استخدام القصص الإكترونية. - تدمج الوسائط المتعددة في القصة الإكترونية. - - تتتج قصة إلكترونية بالتعاون مع المعلمات المشاركات في المجموعة - - تبدع وتبتكر في تصميم وإنتاج القصص الإكترونية. - - تدمج القصص الإكترونية في العملية التعليمة برياض الأطفال. - - مقارن بين البرامج المختلفة المستخدمة في تصميم وإنتاج القصة الإكترونية. 
- - تصمم خلفيات وصور ورسوم وفيديوهات للقصة الإكترونية . - - تحدد العناصر الأساسية اللازم توافرها لتصميم القصص الإكترونية. - - تصمم قصة إلكترونية في ضوء قائمة المعايير التربوية والفنية والتقنية لتصميم وإنتاج القصص الإكترونية.

- تتعرف على إيجابيات برنامج الباوتون وسلبياته في تصميم وإنتاج القصص الإلكترونية.

- تقدر قيمة التعاون مع زميلاتها في تصميم وإنتاج قصة إلكترونية. محتوى البرنامج التدريبي وجلساته:

في ضوء الأهداف التي بسعى البرنامج لتحقبقها، تم تحديد الموضوعات والمهارات

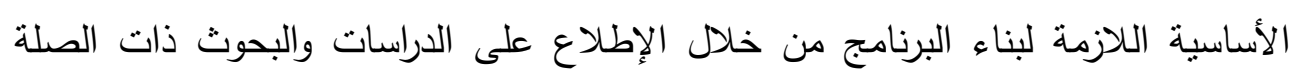

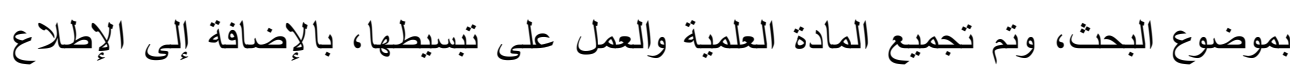

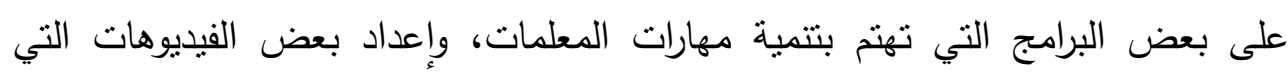

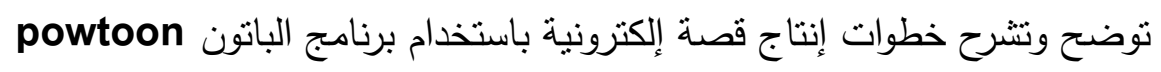
وتم إعداد محتوى البرنامج التدريبي بحيث يشتمل على الجانبين التاليين : الجانب الأول: جاتب نظري (معرفي) ليكون بمثابة خلفية نظرية عن مهارات

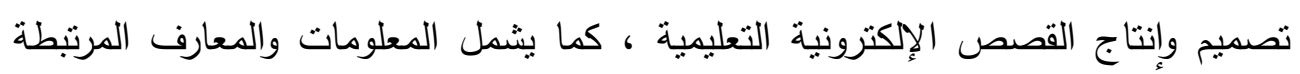
بكل مهارة من المهارات المحددة بالبرنامج.

الجانب الثاني: جاتب عملي (مهارى) ينم فيه تدريب المعلمات من خلال جلسات تدريبية عملية وورش عمل إلكترونية على مهارات تصميم وإنتاج القصص الإكترونية التعليمية المقدمة لطفل الروضة.

كما تم تدريب المعلمات على إنتاج القصص الإكترونية باستخدام برنامج الباوتون

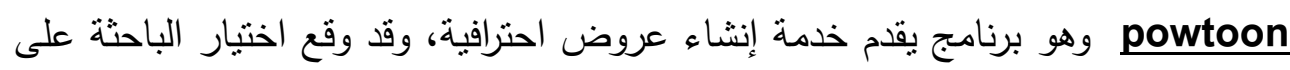


البرنامج لاستخدامه في تدريب المعلمات عينة البحث على تصميم وإنتاج القصص الإلكترونية وذللك بعد الإطلاع على العديد من البرامج ويرجع ذلك إلى : - مناسبة البرنامج للفئة المستهدفة من التدريب (معلمات رياض الأطفال ). - - موقع الباوتون موقع مجاني ومتاح التسجيل فيه للجميع. - - يوفر خلفيات وشخصيات جاهزة لتصميم وإنتاج القصص الإكترونية. - - باستخدامه يمكن تصميم وإنتاج القصص الإلكترونية بسهوله وبأسرع وقت ممكن. وقد تم تتظيم محتوى البرنامج فى صورة مجموعة من الجلسات تحتوى على مجموعة من المعلومات والمعارف عن مهارات تصميم وإنتاج القصص الإلكترونية التعليمية المقدمة لطفل الروضة وكيفية إكساب المعلمات لهذه المهارات وقد روعى فى تتظيم محتوى البرنامج أن تكون المادة العلمية فى مستوى المعلمات وذات أهمية لهن ومراعاة الفروق الفردية والخبرات المتوافرة لدى المعلمات،ومراعاة الإمكانات المتاحة. كما تنظيم جلسات البرنامج التريبي كالتالي :موضوع الجلسة - الهدف العام للجلسة - الأهداف الإجرائية - محتوى الجلسة - الأنشطة التعليمية - الأدوات والوسائل

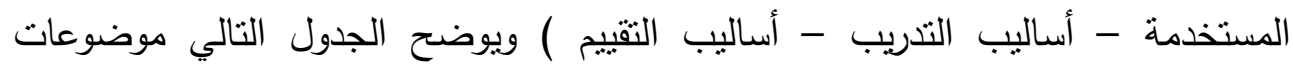
البرنامج التدريبي وجلساته وأساليب التدريب المستخدمة في كل جلسه.

جدول (9):جدول يوضح محتوى البرنامج التدريبى لمعلمات رياض الأطفال وجلساته

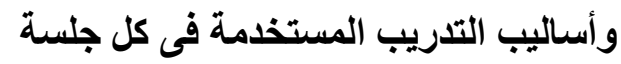

\begin{tabular}{|c|c|c|}
\hline أساليب التدريب المستخدمة فى الجلسة & المحتوى & 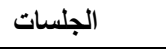 \\
\hline الحوار والمناقشات الجماعية & أدوات البحث قتبلياً (الاختبار المعرفى وبطاقية التبيقة & الجلسة الأولى \\
\hline الحوار والمناقثات الجماعية & 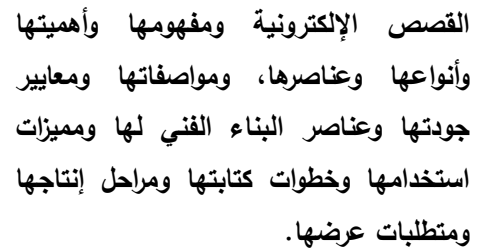 & الجلسة الثانية \\
\hline
\end{tabular}


المجلة العلمية لكلية رياض الاطفال - جامعة اسيوط

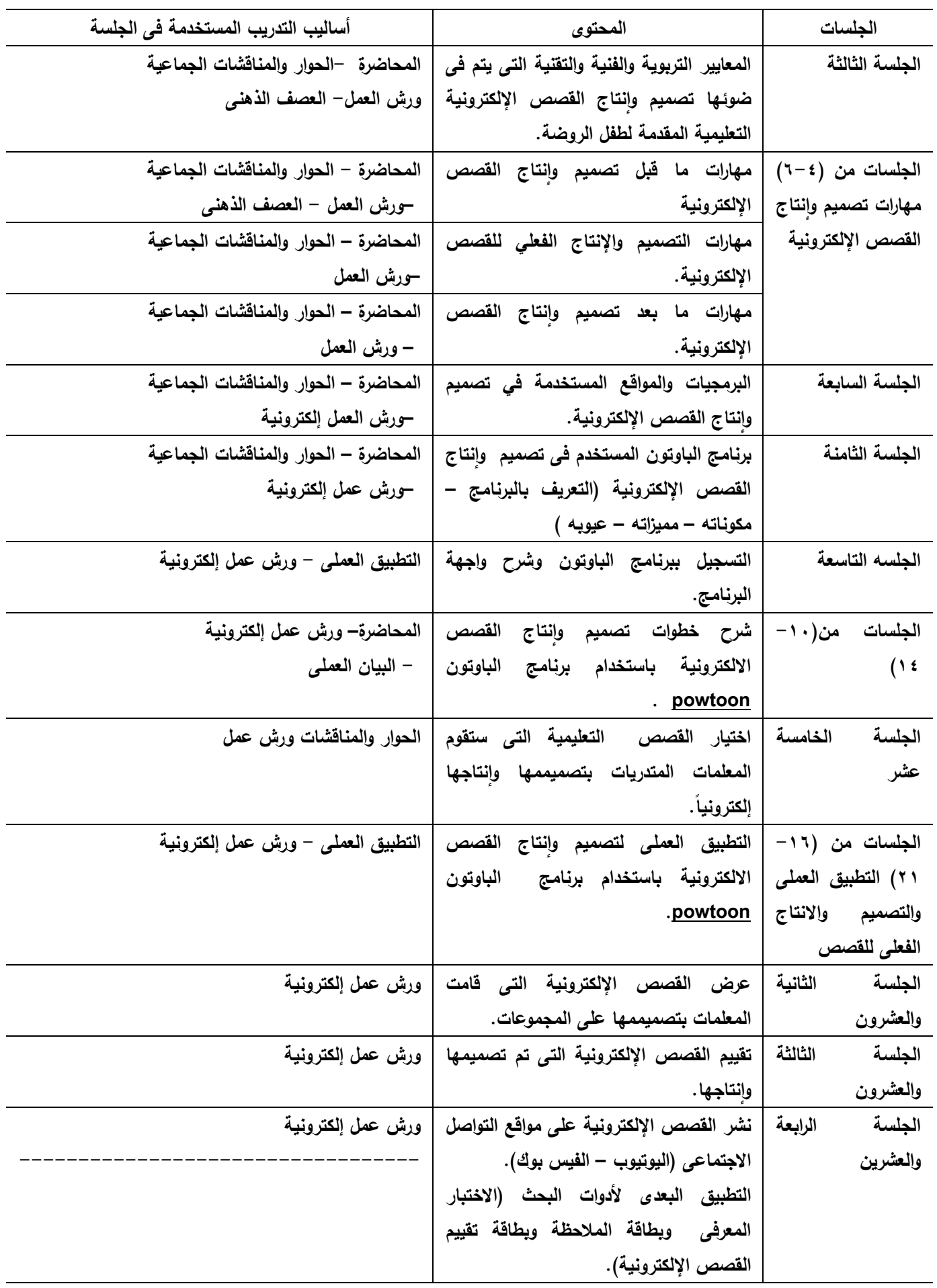


أساليب التدريب المستخدمة في البرنامج التدريبي:استخدت الباحثة بعض

الأساليب المنتوعة للتنريب على البرنامج ومنها :

أولأ: أساليب التدريب الخاصة بالجانب النظري من البرنامج وتمثلت فى :

* المحاضرات النظرية المناقتشة والحوار *العصف الذهني التعلم الذاتي

كما أعدت الباحثة مادة تعليمة مطبوعة لمحتوى كل جلسة تدريبية وتسليمها

للمعلمات المندربات ، كما زودت الباحثة المعلمات المتدربات بنسخة من الفيديوهات التي لهي توضح وتترح بالخطوات كيفية إنتاج وتصميم القصص الإلكترونية باستخدام برنامج الباوتون powtoon.

ثانياً أساليب التدريب الخاصة بالجانب العملي من البرنامج وتمثلت فى: * ورش عمل إلكترونية. * البيان العملي والتطبيق العملى لكل مهارة الأدوات والوسائل التعليمية المستخدة في البرنامج :

استخدمت الباحثة في البرنامج التدريبي العديد من الوسائل التعليمية منها: أجزةة كمبيوتر منصلة بالإنترنيت، وداتا شوا، وبعض العروض التقديمية من إعداد الباحثة، وبعض من لهن الفيديوهات التي توضح ونترح بالخطوات كيفية تصميم وإنتاج القصص الإكترونية باستخدام برنامج الباوتون powtoon، واسطوانات ليزر مدمجة CD محمل عليها البرنامج

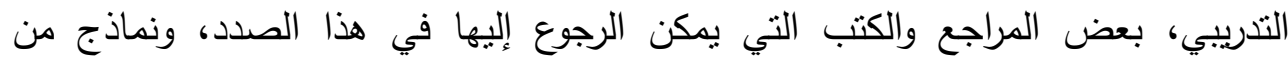
القصص الإلكترونية المناسبة لطفل الروضة. أساليب تقويم البرنامج التدريبي :

التقويم القبلي: نم استخدام هذا النوع من التقويم قبل بدء عرض البرنامج على التى

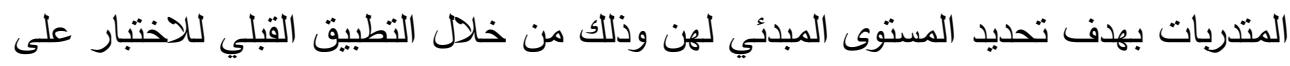
المعلمات لقياس الجانب المعرفي لمهارات تصميم وإنتاج القصص الإلكترونية المقدمة لطفل

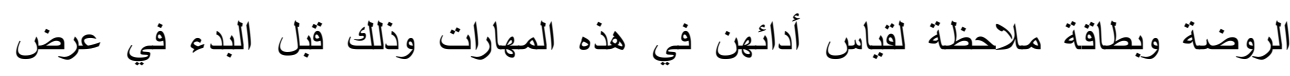
وتدريس البرنامج التدريبي للمعلمات. 
التقويم البنائي (التكويني): وهو النقويم الصصاحب لكل جلسة من جلسات البرنامج

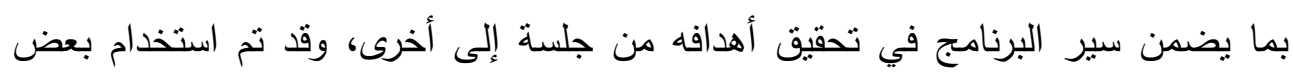

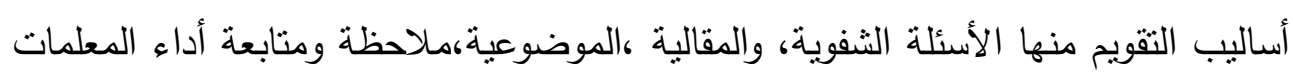
أثناء التدريب، واستمارة التقويم اليومي في نهاية كل يوم تنريبي.

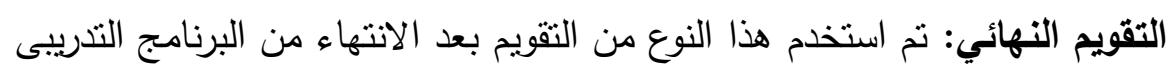

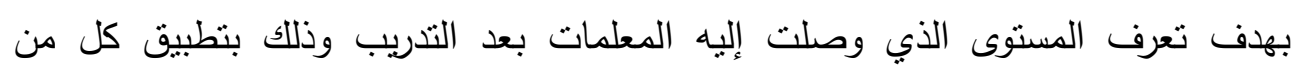

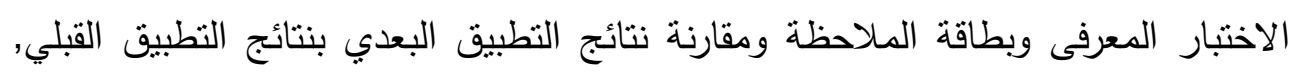

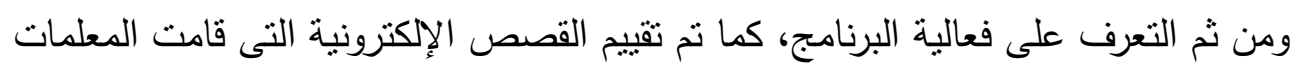

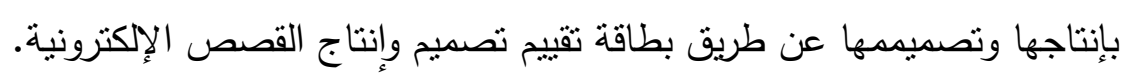
المدى الزمنى لتطبيق البرنامج التدريبى:

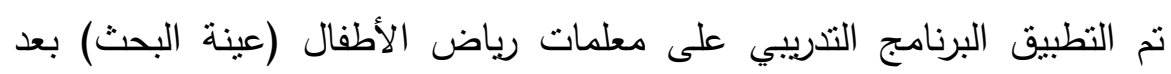

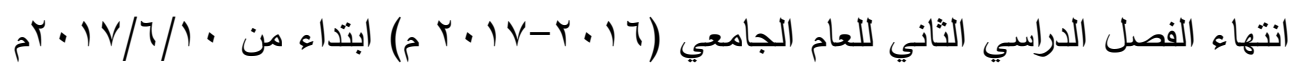

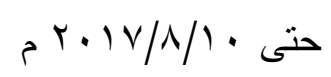
ضبط البرنامج التدريبى :

بعد الانتهاء من إعداد البرنامج تم عرضه في صورته المبئية على مجموعة من المن

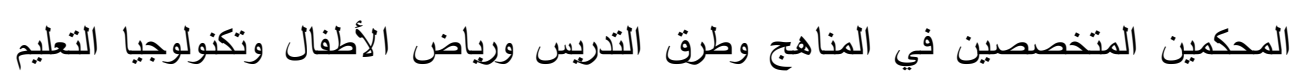

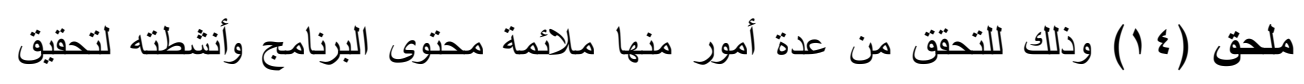

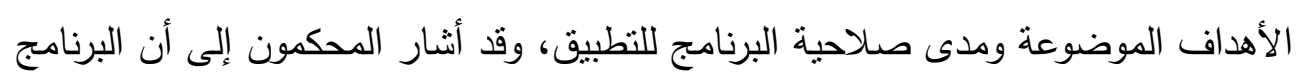

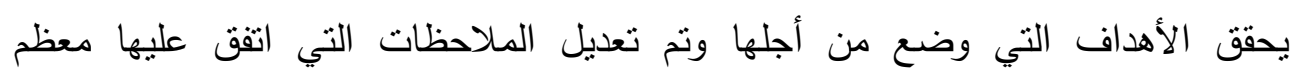

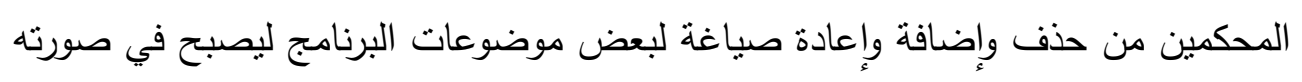

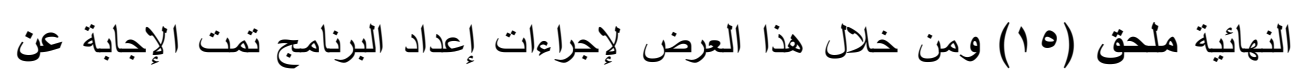
السؤال الرابع من أسئلة البحث. ومن مان. 


\section{خطوات البحث وإجراءاته التجريبية:}

بعد الإنتهاء من إعداد أدوات البحث وضبطها والتأكد من مدى صلاحيتها تتتاول

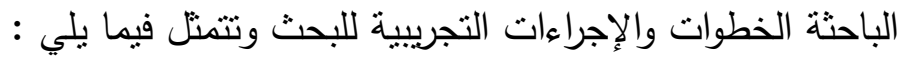

- التطبيق القبلى لأدوات البحث والمتمثلة فى الاختبار المعرفى ويطاقة الملاحظة

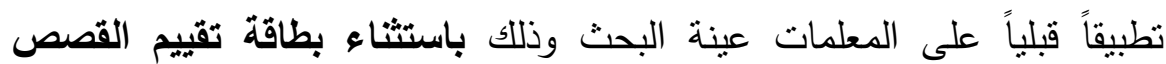
الإكترونية نظراً لعدم معرفة المعلمات عينة البحث بمهارات تصميم وإنتاج

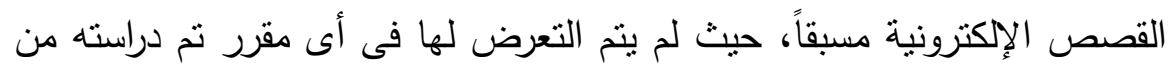
قبل، بالإضافة إلى إنها بطاقة تقييم لمنتج تم تصميمه وإنتاجه.

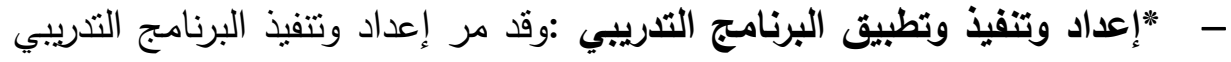

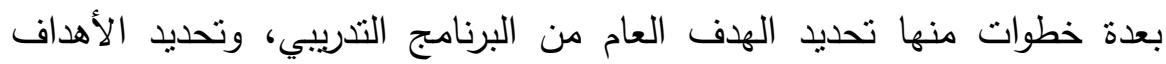
الإجرائية، وتجميع المادة العلمية للبرنامج، وتجميع الصور والرسوم ومقاطع الفيديو من على شبكة الإنترنيت،وتصميم العروض التقديمية وإعداد الفيديوهات التي تنرح وتوضح خطوات ومراحل إنتاج القصص الإلكترونية باستخدام الباونون،عرض

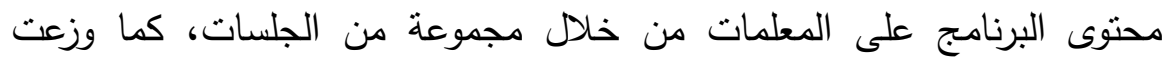
الباحثة على المعلمات المتدربات اسطوانات ليزر CD محمل عليها البرنامج التدريبي الذي يوضح مفهوم القصص الإلكترونية ومراحل وخطوات تصميمها

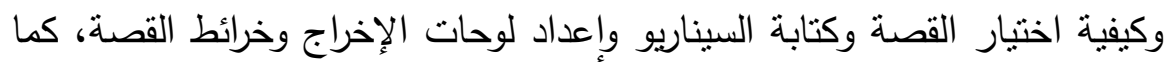
عرضت الباحثة نماذج من القصص الإلكترونية التعليمية المنشورة على شبكة الإنترنيت وذللك لمشاهدتها والتعليق عيها والتعرف نقاط الضعف والقوة في القصص،وعرضت الفيديوهات التي توضح خطوات تصميم القصص باستخدام برنامج powtoon وعرضت قائمة المعايير التربوية والفنية والتقنية التي يتم في لئي ضوئها تصميم القصص الإلكترونية التعليمية لطفل الروضةهوتوزيعها على لئى

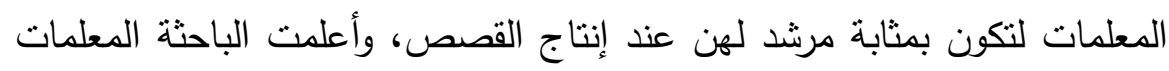
المتدربات أنه سوف ينت عرض قصصهن الإكترونية أمام الباحثة وباقي 
المجموعات مرتين مرة بعد أربعة أسابيع من البدء في تصميم القصص والثانية بعد

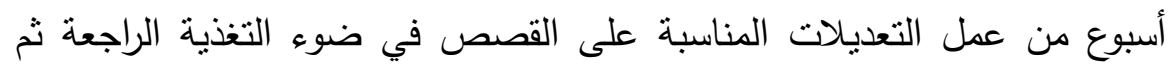
تجميع القصص للتقييم النهائي، ثم تلي ذلك تقسم المعلمات إلى مجموعات وعمل فئل فئل

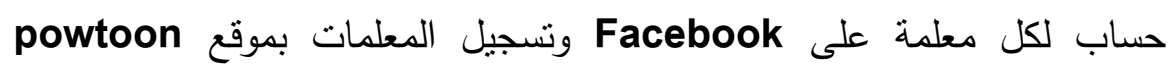
والبدء في تصميم وإنتاج القصص من خلال (تحديد فكرة القصة، وصياغة الأهداف،وكتابة خريطة القصة،ولوحات الإخراج، والسيناريو الخاص بالقصة، تجميع

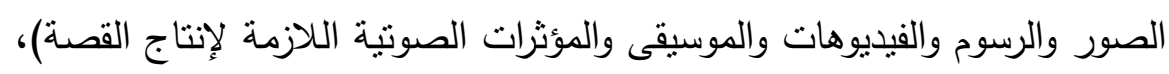
تلي ذلك الإنتاج الفعلي للقصص، وقامت كل مجموعة بتصميم وإنتاج قصنة

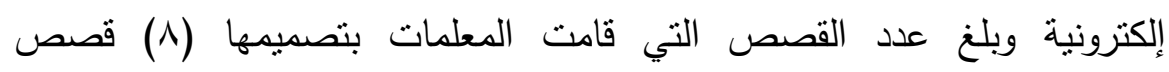
إلكترونية وكانت كالتالي :القصة الأولى بعنوان (هند والثجرة)، القصة الثانية (خالا والألوان)،القصة الثالثة (يوميات أمل)، القصة الرابعة (الجارة الكريمة)،

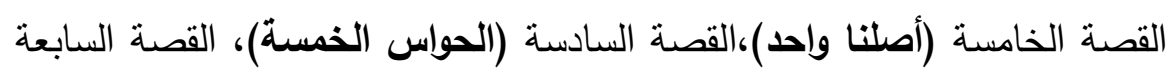
(لم أسمع كلام أمي)، القصة الثامنة (لاتسرف في الماء) وذلك في صورتها النهائية ملحق (17)، ونم نشر القصص الإكترونية بعد الإنتهاء من تصميمها

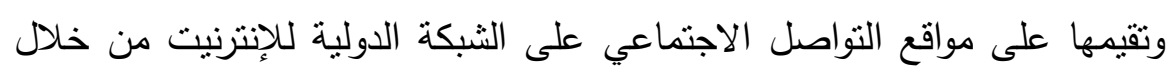
موقع اليوتيوب htt/www.youtyube.com - - التطبيق البعدى للاختبار المعرفي ويطاقة الملاحظة وذلك بعد الإنتهاء من تصميم القصص الإكترونية. - - تقييم القصص الإكترونية التي قامت المعلمات بتصميمها من خلال بطاقة تقييم القصص الإلكترونية.

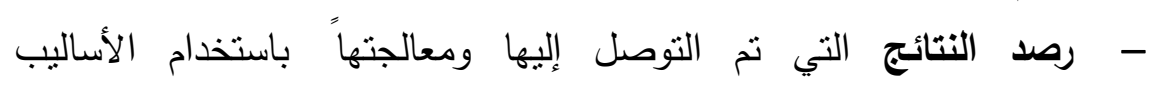
الإحصائية المناسبة باستخدام حزمة البرامج الإحصائية للعلوم الاجتماعية

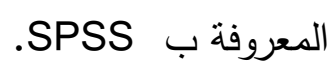

- - تفسير النتائج التي تم التوصل إليها وتقديم التوصيات والمقترحات فى في ضوئها. 
من خلال ما سبق تمت الإجابة عن السؤال الأول والثاني والثالث والرابع من أسئلة البحث وفيما يلي سوف يتم الإجابة عن السؤال الخامس والسادس والسابع والتهابه والتحقق

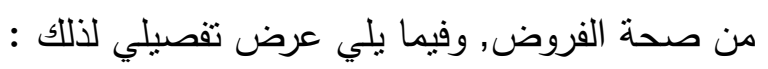
نتائج اختبار صحة الفرض الأول للبحث:

للتحقق من صحة الفرض الأول للبحث ونصه "توجد فروق ذات دلالة إحصائية بين متوسطي درجات المعلمات (عينة البحث) في التطبيق القبلي للاختبار المعرفي

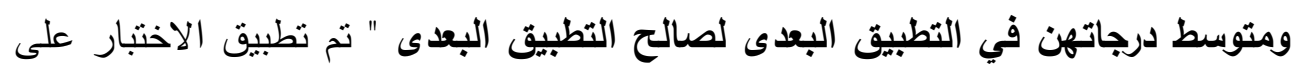

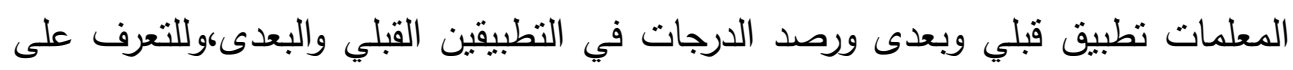
دلالة الفروق بين مجموعة البحث في التطبيقين نم حساب قيمة (ت) للفروق بين متوسطات درجات المعلمات في الاختبار في النطبيقين القبلي والبعدى ويوضح الجدول التالي نتائج

(تنبار (ت) (خ)

جلول ( • 1): نتائج اختبار "ت" للكشف عن دلالة الفروق بين متوسطات درجات مجموعة البحث (ن=rrrr) في التطبيقين القبلي والبعدي للاختبار المعرفي دئي

\begin{tabular}{|c|c|c|c|c|c|c|}
\hline $\begin{array}{c}\text { حجم التأثير } \\
\text { (d) }\end{array}$ & مستوى الالالاية & قيمة "ت" & الانعراف & الحسابي & العدد & (الإحصائية \\
\hline \multirow{2}{*}{ 1..7r } & \multirow{2}{*}{$\cdots 1$} & \multirow{2}{*}{ MY.AV } & $0 . \mu \varepsilon$ & r & rr & القبلي \\
\hline & & & T.rA & $v . . q$. & rr & البعدى \\
\hline
\end{tabular}

يتضح من الجدول السابق وجود فروق دالة إحصائية بين منوسطات درجات

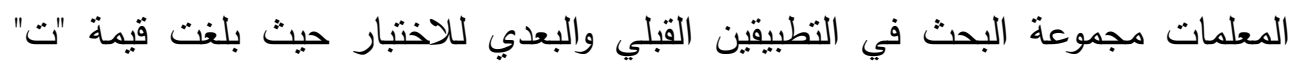
(Y.AV)

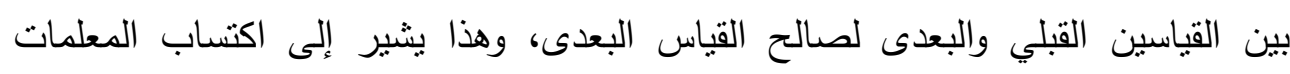
المعلومات والمعارف المقدمة لهن من خلال البرنامج، كما نم حساب حجم الأثر باستخدام

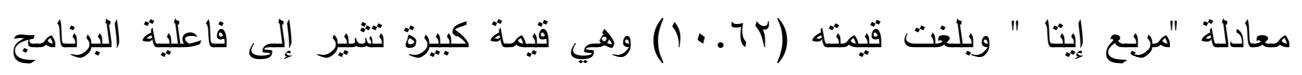




\section{المجلة العلمية لكلية رياض الاطفال - جامعة اسيوط}

التدريبى فى إكساب المعلمات الجانب المعرفي لمهارات تصميم وإنتاج القصص الإكترونية لطفل الروضة ومن النتائج السابقة تم التحقق من صحة الفرض الأول من فروض البحث، كما تمث الإجابة عن السؤال الخامس من أسئلة البحث. تفسير نتائج الفرض الأول:

يتضح من نتائج اختبار صحة الفرض الأول أن دراسة المعلمات للبرنامج التدرييى كان له أثر فعال فى إكتسابهن للجانب المعرفى لمهارات تصميم وإنتاج القصص الإلكترونية المقدمة لطفل الروضة ويرجي ذلك إلىى:

- - مياغة الأهداف السلوكية فى كل جلسة من جلسات البرنامج صياغة واضحة ساعدت المعلمات على إدراك أهداف دراستهن للبرنامج مما أسهم بصورة كبيرة في هلى تحصيلهن للمعلومات والمفاهيم المتضمنة بالبرنامج.

- - - أساليب التدريس التى استخدمت فى تقديم الجانب المعرفى للبرنامج والمتمثلة فى الحوار والمناقثة والعصف الذهنى وحلقات المناقثة بين الباحثة والمعلمات وبين المعلمات وبعضهن البعض أتاحت للمعلمات التعبير عن وجهات نظرهن في جو من الحرية، كما أنها أتاحت الفرصة لبهن الكل معلمة للاشتراك في مناقتشة متبادلة؛ مما أكسبهن التقة بالنفس، وحقق لهن تصوراً أوضح وأثنمل للموضوعات المطروحة واستيعابهن لقدر كبير من المعارف والمعلومات المقدمة لهن من خلهن خلال البرنامج التدريبى.

- - ماستخدام وسائل تعليمية متعددة ومتتوعة وعروض تقديمية وفيديوهات مما أدى إلى

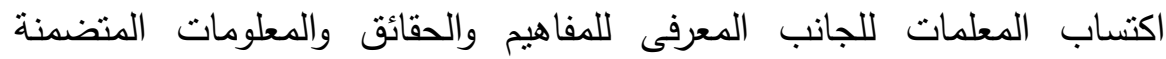
بالبرنامج بكفاءة عالية. - - محاولة المعلمات الإستفادة لأقصي درجة ممكنة من البرنامج التدريبى، ومن ثم

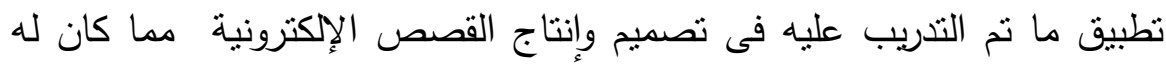
الأثر الإيجابي فى استيعابهن للجانب المعرفي المقدم لهم من خلال وحدات البرنامج وبالتالي الإجابة عن أسئلة الاختبار بكفاءة. 
- حرص الباحثة دائما فى بداية كل جلسة من جلسات البرنامج التدريبى على إثارة انتباه المعلمات من خلال إلقاء اسئلة ذات مغزى يعقب ذلك تعريف المعلمات بموضوعات التعلم بالبرنامج ومحتواها. - التقويم بعد كل لقاء وذلك من خلال وضع أسئلة تشمل المحتوى المعرفي وتطلب

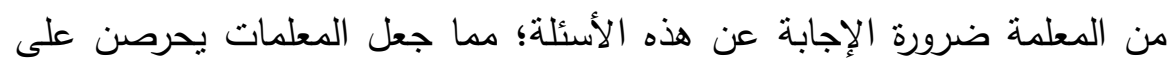
التركيز أثناء الجلسات حتي يتمكن من الإجابة عن الأسئلة. - - - التعزيز الفورى الذى تتلقاه المعلمات من الباحثة فى كل خطوات ومراحل البرنامج التدريبى.

- - تقديم المادة التدريبية للبرنامج على اسطوانات مدمجة CD للمعلمات في بداية البرنامج التنريبي تشمل المحتوى التعليمي للبرنامج والعروض التقديمية والفيديوهات التي توضح وتترح بالخطوات كيفية تصميم وإنتاج القصص الاككترونية باستخدام

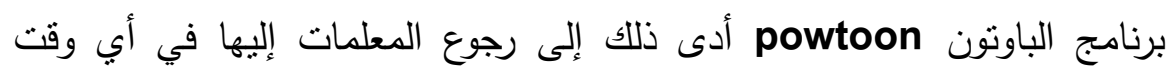

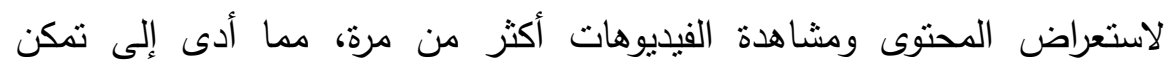
المعلمات من المحتوى التعليمي، وهذا انعكس بصورة إيجابية على أداء المعلمات

$$
\text { في الاختبار المعرفي. }
$$

نتائج اختبار صحة الفرض الثاني للبحث :

للتحقق من صحة الفرض الثاني ونصه "توجد فروق ذات دلالة إحصائية بين

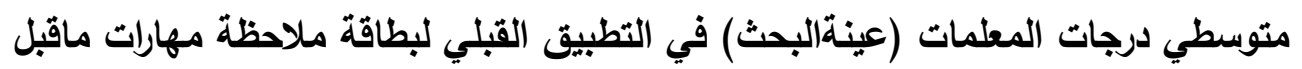
تصميم وإنتاج القصص الإكترونية ومتوسطات درجاتهن في التطبيق البعدى لصاتح التطبيق البعدى" قامت الباحثة بحساب منوسطات درجات المعلمات في التطبيقين القبلي والبعدي لبطاقة ملاحظة مهارات ما قبل تصميم وإنتاج القصص الإلكترونية وحساب لبطي

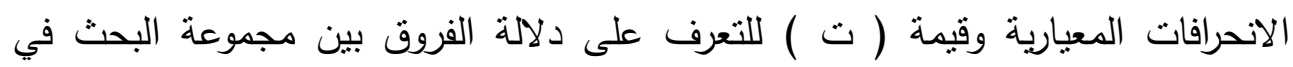

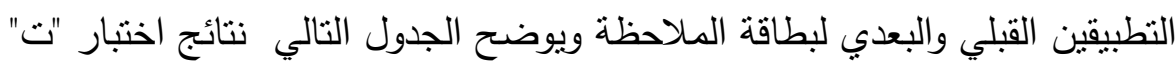


المجلة العلمية لكلية رياض الاطفال - جامعة اسيوط

جدول (11) :نتائج اختبار "ت" للكثف عن دلالة الفرق بين متوسطي درجات مجموعة البحث (ن=rrr)في التطبيقين القبلي والبعدي لبطاقة ملاحظة مهارات ما قبل تصميم وإنتاج القصص الإكترونية

\begin{tabular}{|c|c|c|c|c|c|c|}
\hline $\begin{array}{c}\text { حجم التأثير } \\
\text { (d) }\end{array}$ & مستوى الالالاية & قيمة "ت" & الانحراف & الحسابي & العدد & الإحصائية \\
\hline \multirow{2}{*}{$1 . .79$} & \multirow{2}{*}{$\cdots+1$} & \multirow{2}{*}{51.19} & 0.91 & Tr.vi & rr & القبلي \\
\hline & & & 11.0. & IrT.OV & Tr & البعدى \\
\hline
\end{tabular}

يتضح من الجدول السابق وجود فروق دالة إحصائيا بين منوسطات درجات

المعلمات مجموعة البحث في التطبيقين القبلي والبعدي لمهارات ما قبل تصميم وإنتاج

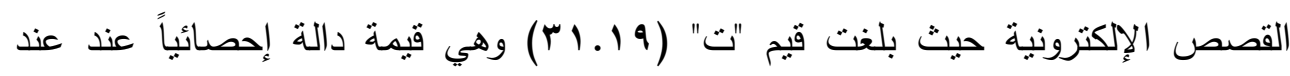

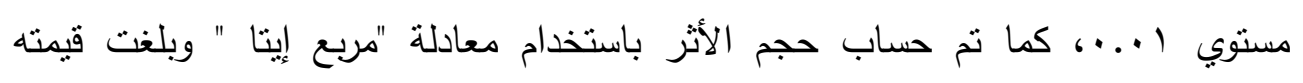
(97. . ( ) وهي قيمة كبيرة تثير إلى تحسن واضح في هذه المهارات لدي المعلمات ويؤكد

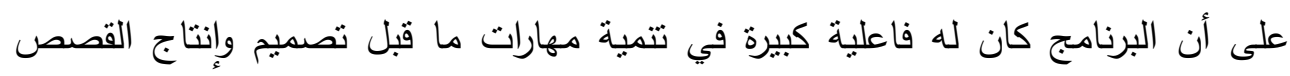

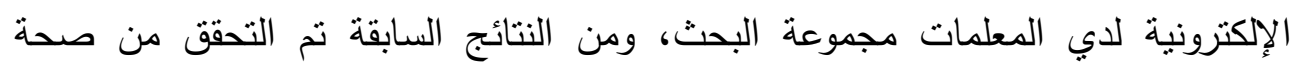

$$
\text { تفرضير الثناني من فروض البحث. }
$$

يتضح من نتائج اختبار صحة الفرض الثاني للبحث أن البرنامج التدريبي كان له

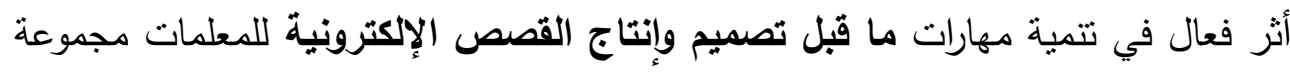

$$
\text { البحث ويرجع ذلك إلى : تمبة }
$$

- - مضوح كل مهارة أساسية من مهارات ما قبل تصميم وإنتاج القصص الإلكترونية

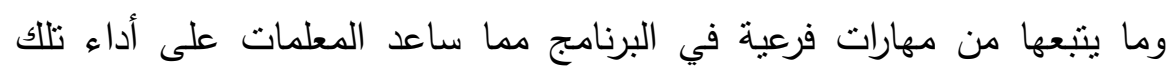

$$
\text { المهارات بدقة. }
$$


- واثر ذلك في خلق قدر ملحوظ من المشاركة الفعالة التي تسهم في تطوير مهارات المعلمات الأدائية.

- - مرش العمل الإكترونية التي أجرتها الباحثة لتكريب المعلمات عملياً مما كان لها أثثر كبير في إتقانهن لتلك المهارات. وتتفق هذه النتيجة مع دراسة حسن عبد الباسط (• (ب. (Y)، ودراسة داليا شوقي

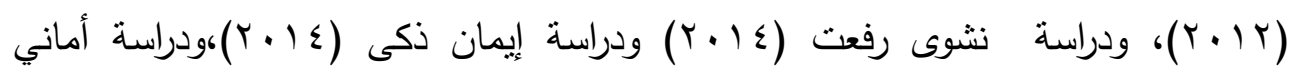

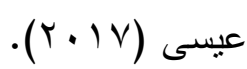
نتائج اختبار صحة الفرض الثالث للبحث : للتحقق من صحة الفرض الثالث ونصه "توجد فروق ذات دلالة إحصائية بين متوسطي درجات المعلمات (عينة البحث) في التطبيق القبلي لبطاقة ملاحظة مهارات التصميم والإنتاج الفعلي للقصص الإكترونية ومتوسط درجاتهن في التطبيق البعدى

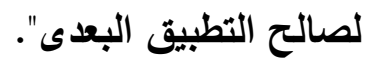
قامت الباحثة بحساب منوسط درجات المعلمات في التطبيقين القبلي والبعدي لبطاقة ملاحظة مهارات التصميم والإنتاج الفعي للقصص الإكترونية وحساب الانحرافات المعيارية وقيمة ( ت ) للتعرف على دلالة الفروق بين مجموعة البحث في التطبيقين القبلي

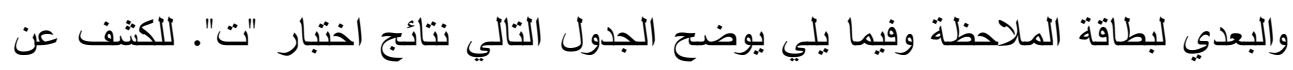

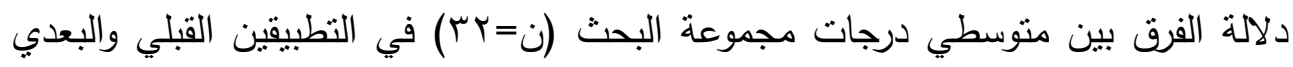

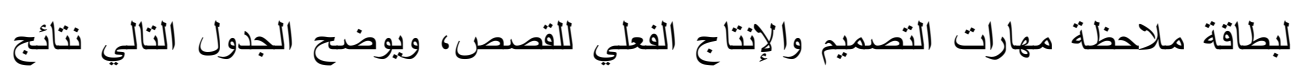


جدول (r ( ): نتائج اختبار "ت" للكثف عن دلالة الفرق بين متوسطي درجات مجموعة

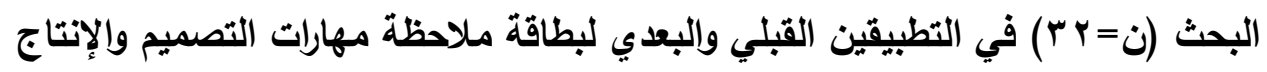
الفعلي للقصص الإكترونية

\begin{tabular}{|c|c|c|c|c|c|c|}
\hline $\begin{array}{c}\text { حجم التأثير } \\
\text { (d) }\end{array}$ & الالالة الإحصائية & قيمة "ت" & المعيارى & الحسابي & العدد & الإحصيائية \\
\hline \multirow{2}{*}{1.04} & \multirow{2}{*}{$\ldots 1$} & \multirow{2}{*}{ r... } & V.०0 & 78.11 & rY & القبلي \\
\hline & & & 9.70 & IFI.r. & rr & البعدى \\
\hline
\end{tabular}

يتضح من الجدول السابق وجود فروق ذات دالة إحصائية عند مستوي ا ل.. بين متوسطي درجات مجموعة البحث في النطبيقين القبلي والبعدي لمهارات ما قبل تصميم

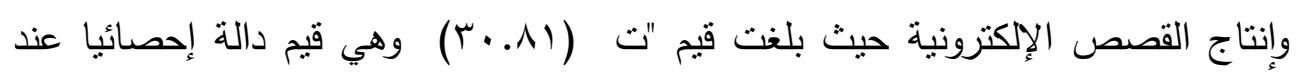
مستوي ا....، كما نم حساب حجم الأثر باستخدام معادلة "مربع إيتا " وبلغت فيمته

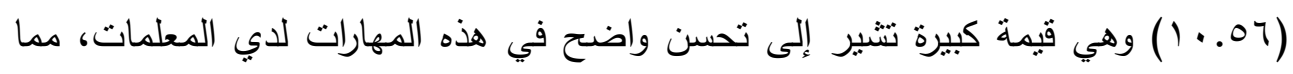
يدل على أن البرنامج كان له فاعلية كبيرة في تتمية مهارات التصميم والإنتاج الفعلي

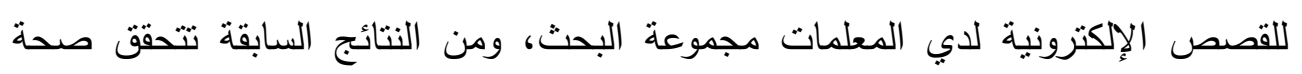

$$
\text { تفرير نتائج الفرض الثالث من فروض البحث. }
$$

يتضح من نتائج اختبار صحة الفرض الثالث أن البرنامج التنريبي كان له أثر فعال في تتمية مهارات التصميم والإنتاج الفعلي للقصص الإكترونية لاي المعلمات مجموعة البحث ويرجع ذلك إلىى: فئ

- - مضوح كل مهارة أساسية من مهارات التصميم والإنتاج الفعلي للقصص الإككترونية

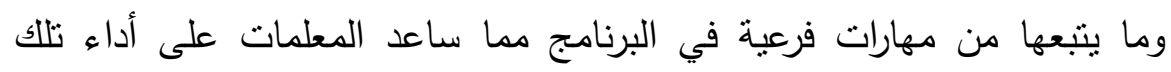

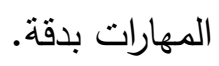

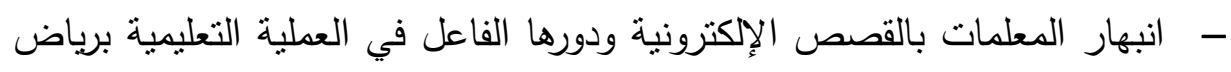
الأطفال مما كان له أثر كبير في إتقان المعلمات لتلك المهارات. 
- - رغبة المعلمات في المشاركة الإيجابية في إنتاج القصص الإكترونية ومن مظاهر

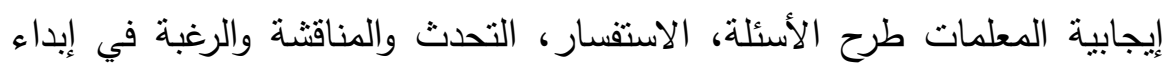
الرأي والمشاركة الفعالة في ورش العمل الإلكترونية.

- - حرص المعلمات على التتافس الثديد داخل مجموعات العمل وصولاً لأفضل قصة إلكترونية.

- - تحسين أداء المعلمات نتيجة استخدام الباحثة أساليب التعزيز المختلفة (مادية ومعنوية).

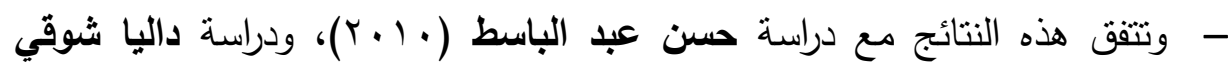

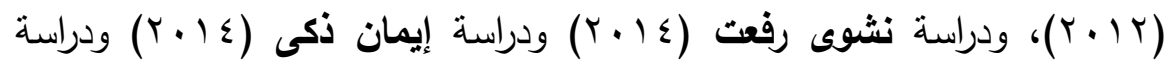

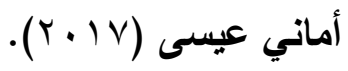

نتائج اختبار صحة الفرض الرايع للبحث :

للتحقق من صحة الفرض الرابع ونصه " توجد فروق ذات دلالة إحصائية بين

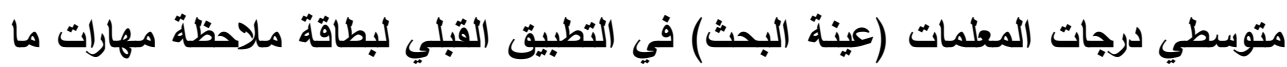
بعد تصميم وإنتاج القصص الإكترونية ومتوسط درجاتهن في التطبيق البعدى لصالح

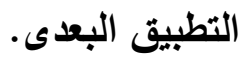

قامت الباحثة بحساب متوسط درجات المعلمات في التطبيقين القبلي والبعدي لبطاقة ملاحظة مهارات ما بعد تصميم وإنتاج القصص الإلكترونية وحساب الانحرافات المعيارية وقيمة (ت) للتعرف على دلالة الفروق بين مجموعة البحث في التطبيقين القبلي والبعدي ويوضح الجدول التالي نتائج اختبار "ت". 
جدول (r I ): نتائج اختبار "ت" للكشف عن دلائة الفرق بين متوسطي درجات مجموعة البحث (ن=rrrr في التطبيقين القبلي والبعدي لبطاقة ملاحظة مهارات ما بعد تصميم وإنتاج القصص الإكترونية

\begin{tabular}{|c|c|c|c|c|c|c|}
\hline حجم التأثير & الدلاية الإحصائية & قيمة "ت" & الانحراف & المستوسط & العدد & 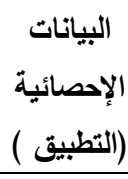 \\
\hline \multirow{2}{*}{$1 . . \wedge \mathrm{V}$} & \multirow{2}{*}{$\cdots 1$} & \multirow{2}{*}{ TI.V $\varepsilon$} & $\varepsilon .74$ & 79.1. & rr & القبلي \\
\hline & & & 14.9 & Irی.s. & rr & البعدى \\
\hline
\end{tabular}

يتضح من الجدول السابق وجود فروق دالة إحصائية بين متوسطات درجات المعلمات مجموعة البحث في التطبيقين القبلي والبعدي في مهارات ما بعد تصميم وإنتاج

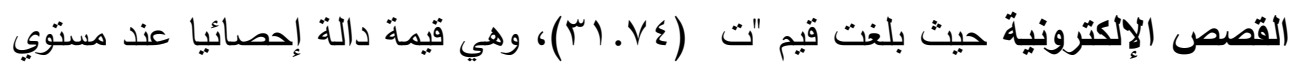

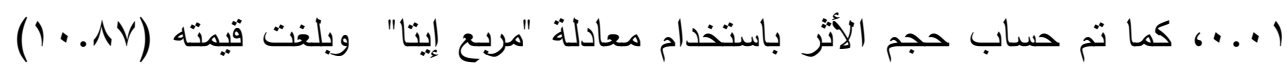

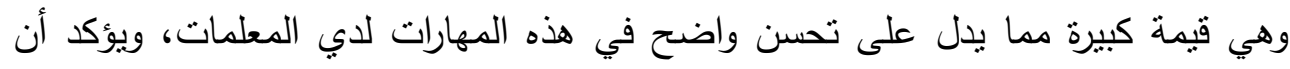

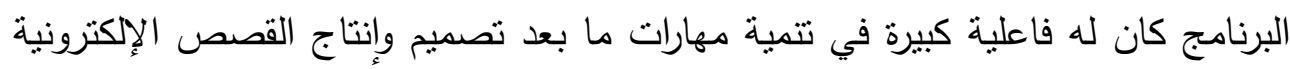

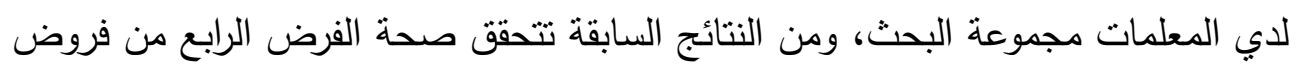
البحث، كما تمت الإجابة عن السؤال السادس من أسئلة البحث.

تفسير نتائج الفرض الرابع:

يتضح من نتائج اختبار صحة الفرض الرابع أن البرنامج التدريبي كان له أثر فعال في نتمية مهارات ما بعد تصميم وإنتاج القصص الإلكترونية المعلمات مجموعة البحث البرن

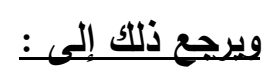

- زيارة المعلمات لبعض المواقع الإلكترونية ومشاهدة قصص إلكترونية على اليوتيوب htt//www.youtyube.com دافعيتهن ورغبتهن الثديدة لتصميم وإنتاج القصص الإكترونية. - - رغبة المعلمات في التميز وإنتاج قصص إلكترونية تعليمية جيدة مما أدى إلى زيادة التتافس فيما بينهن. *تثارك المعلمات لقصصهم الإكترونية عبر أدوات التشارك 
الإلكتروني المتاحة لهم بالموقع أدى إلى زيادة دافعيتهن لإنتاج قصص إلكترونية

متميزة.

- - روح المودة والاحترام والتعاون التي سادت بين المعلمات عملت على تتمية ثقتهن

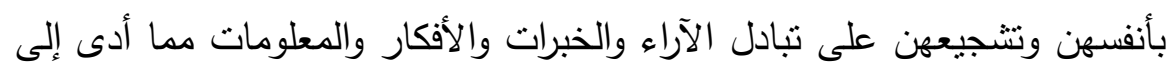
تحسن الأداء المهارى لهن في إنتاج القصة الإلكترونية.

- - إنجاز المهام المطلوبة من المعلمات أثثاء ورش العمل الإلكترونية مما أدى إلى ارتفاع مستوى أداء المعلمات واتقاهن للمهارات.

- مساعدة الباحثة للمعلمات في حالة طلب العون والمساعدة أو الاستفسار عن أي معلومة تساعدهن في تصميم وإنتاج القصص الإلكترونية.

- استخدام تكنولوجيا الوسائط المتعددة في تقديم محتوى البرنامج التدريبي من خلال مشاهدة أدق التفاصيل في أداء المهارة من خلال مقاطع فيديو رقية العية. - - تبادل الخبرات والمعلومات بين المعلمات مما أدى إلى تحسن الأداء المهارى لهن في إنتاج القصة الإلكترونية. - روئة كل مجموعة لقصص المجموعات الأخرى ونشرها عبر مواقع التواصل الاجتماعي أدت إلى الرغبة في التتافس وتحسن الأداء المهارى للمعلمات في تصميم وإنتاج القصص الإلكترونية.

- متابعة الباحثة للمعلمات في كل مراحل تصميم وإنتاج القصص الإكترونية وإعطاءهن الإرشادات والتوجيهات وحثهن على الإتقان وتجويد الأداء.

وتتفق هذه النتائج مع دراسة حسن عبد الباسط (• ( •Y)، ودراسة داليا شوقي

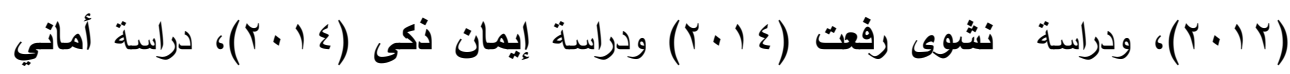

$$
\text { عيسى (Y) (Y) (Y) (Y) (Y) (Y) }
$$


نتائج اختبار صحة الفرض الخامس للبحث :

للتحقق من صحة الفرض الخامس ونصه "توجد فروق ذات دلالة إحصائية بين متوسطي درجات المعلمات (عينة البحث) طبقا لبطاقة تقييم القصة الإكترونية التعليمية

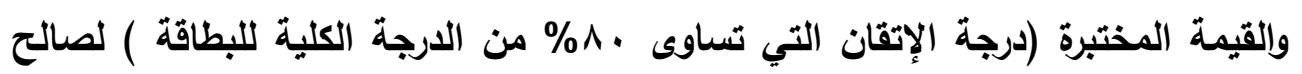

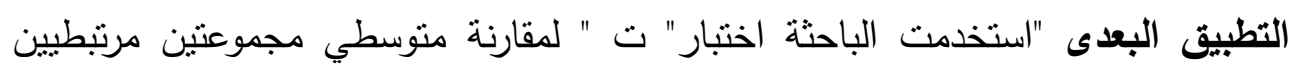
وهما متوسط درجات المعلمات في القياس البعدى لبطاقة تقييم القصص الإلكترونية بالقيمة

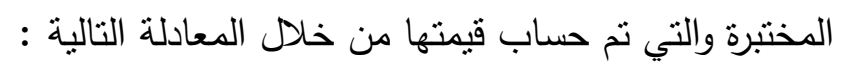
1.x القيمة المختبرة = المجموع الكلى لارجة بطاقة الملاحظة 1.. وفيما يلي يوضح الجدول التالي نتائج اختبار "ت". جدول (؛ 1): قيمة "ت" لأفراد عينة البحث في التطبيق البعدى لبطاقة تقييم القصص

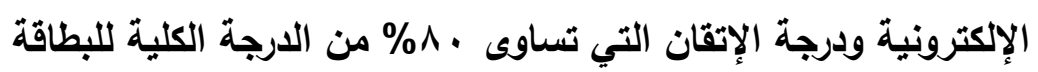

\begin{tabular}{|c|c|c|c|c|c|c|c|}
\hline $\begin{array}{l}\text { حجأثمر } \\
\text { (d) }\end{array}$ & مستوى الالالاية & قيمة "ت" & الانعراف المعيارى & الحستوسط & التطبيق & اللعظمى اللارجة & التطبيق \\
\hline \multirow[t]{2}{*}{$\cdots 9$. } & \multirow{2}{*}{$\cdots 1$} & \multirow[t]{2}{*}{ Ir.rY } & $0.7 \varepsilon$ & 107.11 & بعدى & \multirow[t]{2}{*}{$1 \vee \wedge$} & الارجة \\
\hline & & & \multicolumn{2}{|c|}{$1 \leqslant Y . \varepsilon$} & درجة الإتقان & & للبطاقة \\
\hline
\end{tabular}

يتضح من الجدول السابق وجود فروق ذات دلالة إحصائية عند مستوي ا ب.. ب بين

متوسطي درجات مجموعة البحث في النطبيق البعدي لبطاقة تقييم القصص الإكترونية

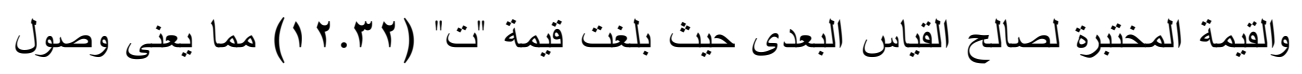

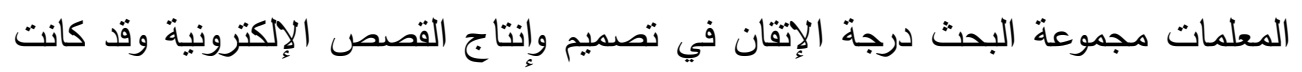

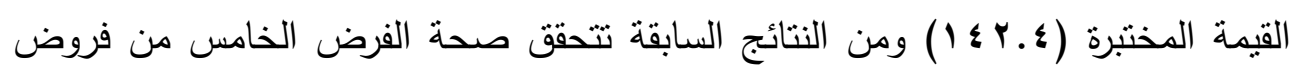
البحث، كما تمت الإجابة عن السؤال السابع من أسئلة البحث. 


\section{تفسير نتائج الفرض الخامس:}

يمكن تفسير نتائج الفرض الخامس ووصول المعلمات عينة البحث لمستوى الإتقان (\%^•)

- وعى المعلمات بعناصر القصة الإلكترونية ومراحل تصميمها وإنتاجها، والمعايير التربوية والفنية والتقنية التي ينم في ضوعئها تصميم وإنتاج القصص الإكترونية التعليمية لطفل الروضة.

- عرض نماذج من القصص الإلكترونية التعليمية ومناقثتها مع المعلمات وتحديد نقاط القوة والضعف فيها بشكل تقصيلي. - المناقثات الناقدة التي أجرتها الباحثة مع المعلمات أثناء عرض القصص الإكترونية الخاصة بكل مجموعة. - عرض القصة الإلكترونية لكل مجموعة أمام المجموعات الأخرى مما أدى إلى فالى زيادة التتافس فيما بينهن والثقة بالنفس. - - إعتماد المعلمات على أنفسهن في تجميع واختيار وإنتاج القصص الإكترونية مما أدى إلى زيادة إحساسهن بالمسئولية أثناء تصميم وإنتاج القصص إنصاد الإلكترونية التعليمية.

- - عرض قائمة المعايير التربوية والفنية والتقنية التي يتم في ضوئها تصميم القصص الإلكترونية التعليمية لطفل الروضة،هوتوزيعها على المعلمات فكانت بمثابة مرشد

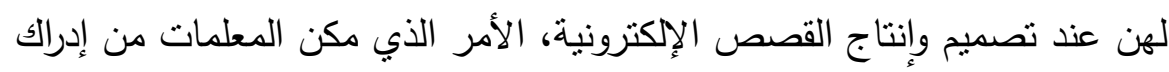
أهمية المعايير والحرص على تحقيق كل منها في القصص التي قاموا بتصميمها. - - الاستعداد الكبير والرغبة الثديدة لدى المعلمات لإنتاج قصص الكترونية تعليمية ذات هدف محدد واستمتاعهن بمراحل إنتاجها وقدرتهن على جمع المعلومات والوسائط المتعددة (صوت وصورة ومقاطع فيديو وموسيقى ومؤثرات صوتية) الني يستخدمونها

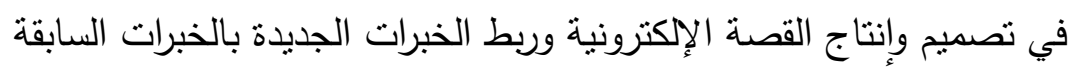


- تتوع وسائل الاتصال بين الباحثة والمعلمات والإجابة عن استفساراتهن وتوضيح النقاط الصعبة مما ساعد على تبادل الخبرات فيما بينهن واستعدادهن لإنتاج القصص الإكترونية وتتشاركها.

- تواصل وتعاون الباحثة مع المعلمات أثناء تصميم وإنتاج القصص الإلكترونية أدى

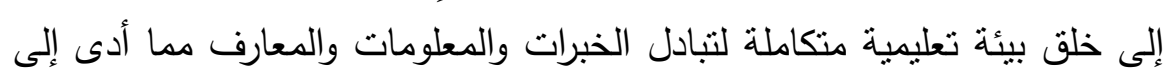
إنتاج قصص إلكترونية متميزة. - - تقسيم المعلمات في معظم أوقات التدريب وأثناء ورش العمل وممارسة الأنشطة في

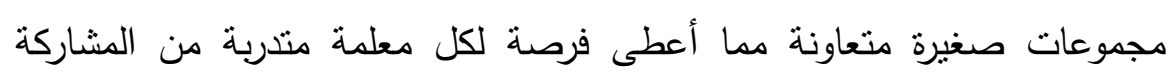
الفعلية في تصميم وإنتاج القصص الإكترونية.

- - تشجيع المعلمات وبث الثقة في نفوسهم من خلال تكليفهم ببعض المهام والأعمال وإتاحة الفرصة لهن للتعبير عن آرائهن وأفكارهن.

- - استخدام أساليب التعزيز طوال فترة التدريب مما أدى إلى وجود روح المنافسة بين المعلمات وبعضهن البعض. - شعور المعلمات بقيمة القصة الإكترونية واستمتاعهن في كل مراحل تصميم وإنتاج

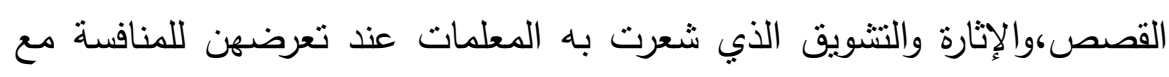

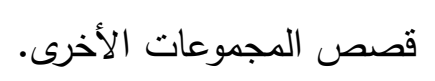

وتتفق هذه النتائج مع نتائج دراسة نشوى رفعت (ع ا • Y) ودراسة إيمان الشريف

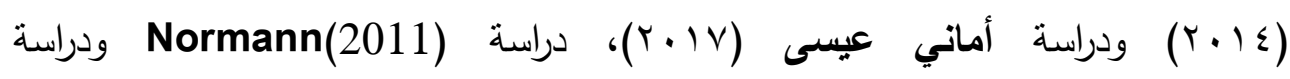
Hutchison(2012) المهارات التكنولوجية التي من شأنها تحسين كل الجوانب التعليمية للمتعلم.

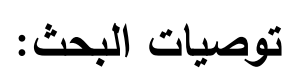
في ضوء ما توصل إليه البحث من نتائج يمكن تقديم التوصيات التالية : 
- تبنى معلمات رياض الأطفال وأعضاء هيئة التدريس بكليات رياض الأطفال وبأقسام تربية الطلل بكليات التربية مداخل تعليمية جديدة تلائم عصر التقافة الإلكترونية والرقمية ومنها مدخل القصص الإلكترونية.

- استخدام القصص الإكترونية كأحد صور المشروعات التي يمكن تقديمها في مختلف المقررات الدراسية كمشروع التخرج فى مرحلة البكالوريوس بكليات رياض الأطفال وأقسام تربية الطفل.

- ضرورة تحديث برامج إعداد معلمة رياض الأطفال بأقسام وشعب تربية الطفل بكليات التربية وكليات رياض الأطفال في ضوء الاتجاهات العالمية الحديثة وتضمينها التدريب العملي على استخدام التعليم الإلكتروني في عمليتي التعليم والتعلم في رياض الأطفال.

- ضرورة إعادة النظر في محتوى البرامج التدريبية المقدمة لمعلمات رياض الأطفال أثثاء الخدمة والتي تتظمها وزارة التربية والتعليم لتلبى حاجة المعلمات في مسايرة التطور التكنولوجي برياض الأطفال وتفعيل تقنياته.

- توجيه جميع القائمين على تصميم وإنتاج القصص الإلكترونية بالاستعانة بقائمة مهارات تصميم وإنتاج القصص الإلكترونية التي تم التوصل إليها في إنتاج القصص الإكترونية التعليمية لطفل الروضة.

- عقد دورات تدريبية لمعلمات رياض الأطفال أثناء الخدمة عن القصص الإكترونية

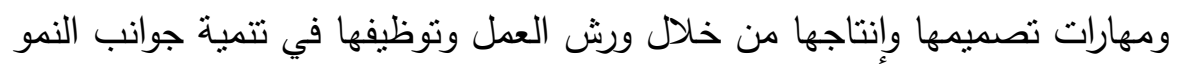
المختلفة لطفل الروضة.

- وضع خطة تربوية متكاملة تستهدف استخدام القصص الإلكترونية التعليمية في تتمية المفاهيم والقيم المناسبة لمرحلة رياض الأطفال وجميع المراحل التعليمية. - العمل على تفعيل المعلمات للقصص الإلكترونية بالروضات وتقديمها بالثكل المناسب للأطفال في هذه المرحلة. 
- تحويل القصص الورقية المناسبة لطفل الروضة إلى قصص إلكترونية. - إعداد دليل لمعلمات رياض الأطفال لتعريفهن بالقصص الإلكترونية ومفهومها أهميتها وأنواعها ومهارات تصميمها وإنتاجها.

\section{البحوث المقترحة:}

- فاعلية برنامج مقترح في تتمية مهارات تصميم القصص التعليمية الإكترونية للطالبة معلمة رياض الأطفال.

- تدريب معلمات رياض الأطفال على تصميم وإنتاج القصص الإلكترونية باستخدام برامج متعددة.

- دراسة تقويم أداء معلمات الروضة واتجاهاتهن نحو تصميم وإنتاج القصص الإلكترونية لطفل الروضة.

- دراسة مسحية للتعرف على أنواع البرامج المستخدمة في تصميم وإنتاج القصص الإلكترونية لطفل الروضة. 


\section{المراجن}

\section{أولاً المراجع العربية}

ا ـ إبراهيم أبو اليزيد الدرينى(ع 1 ـ r): فاعلية وحدات دراسية باستخدام القصص الرقمية في تطوير بعض المهارات الحركية الأساسية والمفاهيم المعرفية لمرحلة رباض الأطفال، رسالة دكتوراه، كلية التربية الرياضية، جامعة الإسكندرية.

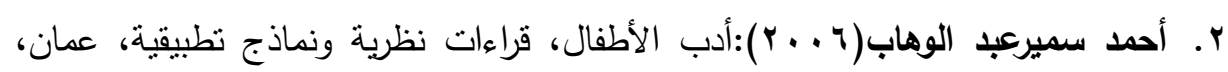
الأردن، دار المسيرة.

r. أمل عبد القتاح سويدان (11 (r): تصميم برنامج قائم على الأشطة الإكترونية

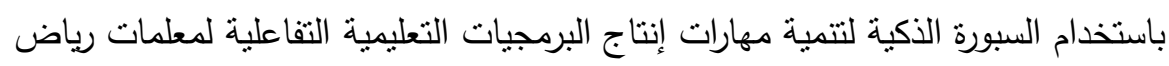
الأطفال, وأثز ذلك في تتمية مهارات التفكير المنطقي للطفل , مجلة تكنولوجيا التربية

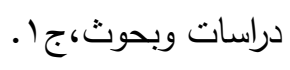

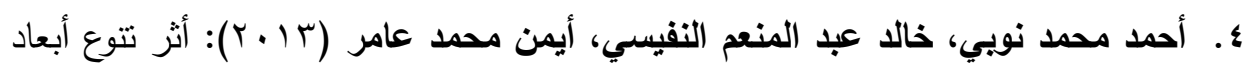
الصورة في القصة الإلكترونية على تتمية الذكاء المكاني لتلميذات الصف الأول الابتدائي ورضا أولياء أمورهن، المؤتمر الدولي الثالث للتعليم الإكتروني عن بعد، الرياض. ه. أسعد على السيد رضوان (11 • (1): إنتاج القصة التفاعلية في برامج الكمبيوتز التعليمية وفاعليتها في تعليم الأطفال المهارات الحياتية، رسالة ماجستير، كلية التربية، جامعة حلوان.

צ. إسلام عبد الغفار على خليل (ع ا ب r): أثز مستويات التفاعل في القصة الإكترونية المصورة في تتمية الثقافة البصرية لمرحلة رياض الأطفال، رسالة دكتوراه غير منشورة، كلية التربية، جامعة حلوان.

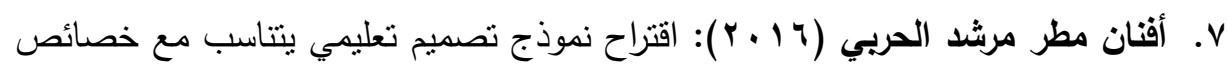

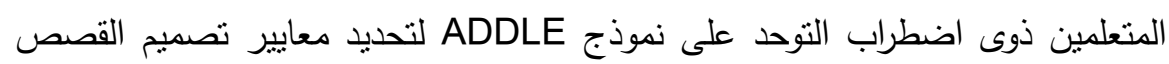
التعليمية الاجتماعية الإكترونية، رسالة ماجستير ، كلية التربية، جامعة الملك سعود. 


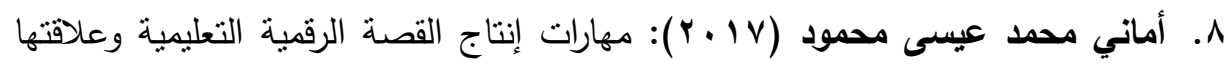

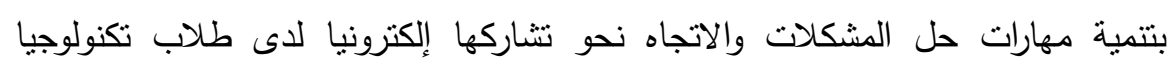
التعليم، رسالة ماجستير، كلية التربية النوعية، جامعة المنيا.

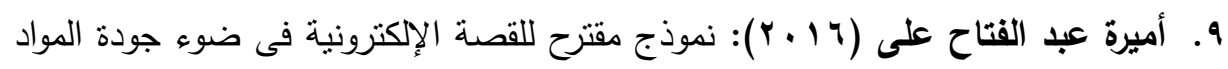

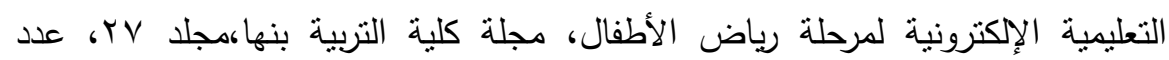

$$
\text { .) (1) }
$$

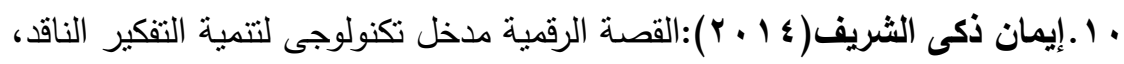

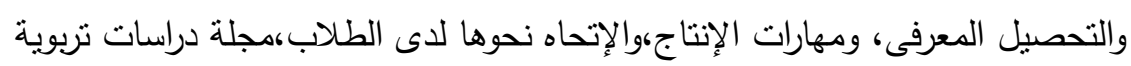

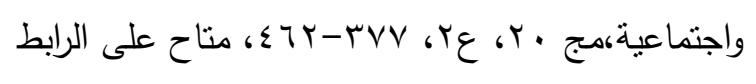

\section{http://search.mandumah.com/Record/740898}

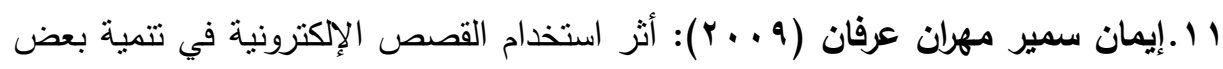
المفاهيم الاجتماعية لطفل ما قبل المدرسة، رسالة ماجستير ، كلية التربية، جامعة المنيا.

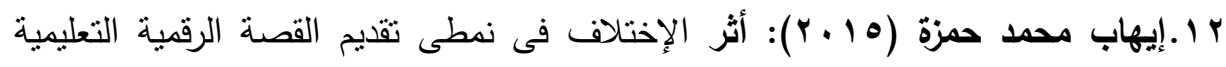

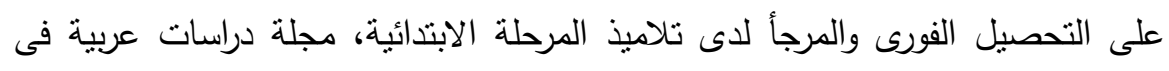

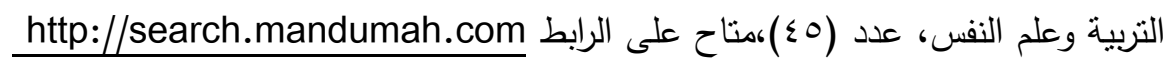

\section{/Record/700037}

r ا.بثينة محمد سعيد قريان (r 1 ب): فاعلية استخدام قصص الرسوم المتحركة في تتمية

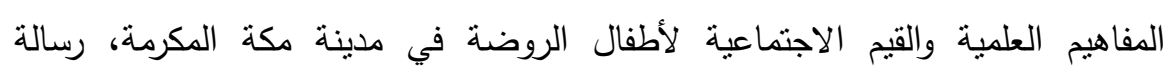

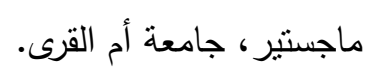

؛ ا.حسين محمد أحمد عبد الباسط (17 (Y): مواقف عملية لاستخدام حكي القصص

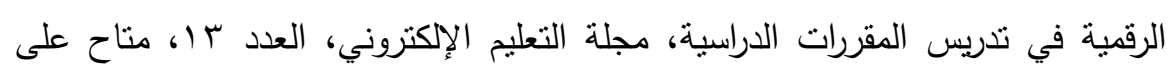
الرابط

htt:// emag mans.edu.eg/index.php? pape=news\&task=show\&id4312016/4. 
1 ا.حنان صلاح الدين صالح حسنين (10 ب ب): أثر التفاعل بين الثخصية الدرامية ولغة الحوار داخل القصة الإلكترونية التفاعلية التعليمية على إكسابهم مهارات الثقافة البصرية لاى نلاميذ الحلقة الإبتدائية، رسالة دكتوراة، كلية التربية، جامعة القاهرة.

19

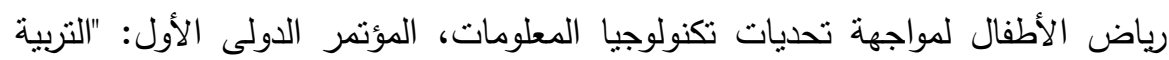

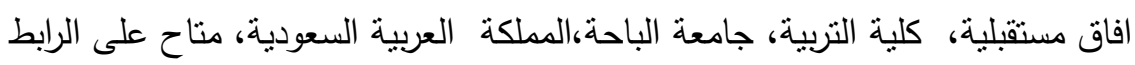
https://portal.bu.edu.sa/conferences/_/journal_content/ 56_INSTANCE.../43852363

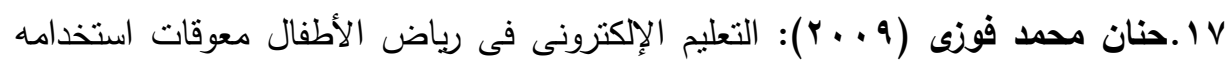

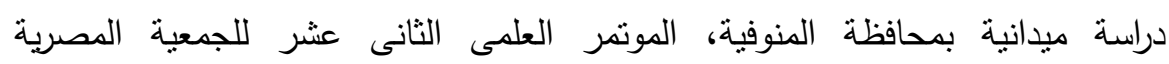
لتكنولوجيا التعليم بين تحديات الحاضر وافاق المستقبل، الجمعية المصرية لتكنولوجيا التعليم، كلية البنات، جامعة عين شمس.

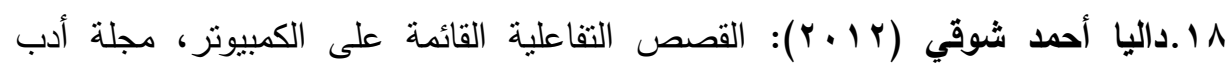
الأطفال، دراسات وبحوث، العدد الرابع، القاهرة، دار الكتب والوثائق القومية.

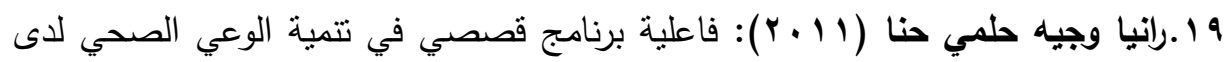

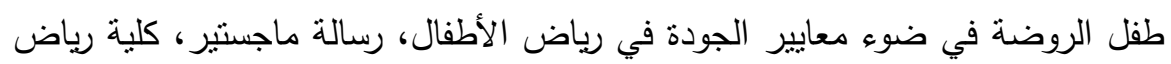

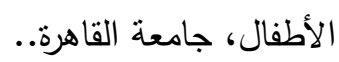

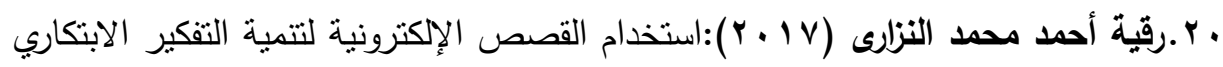
لطفل ما قبل المدرسة بالمملكة العربية السعودية، رسالة ماجستير ، جامعة القاهرة، كلية التربية للطفولة المبكرة.

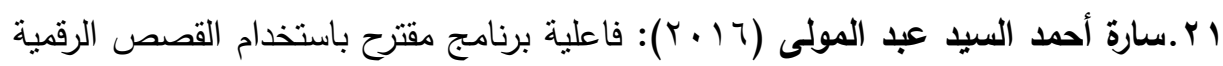

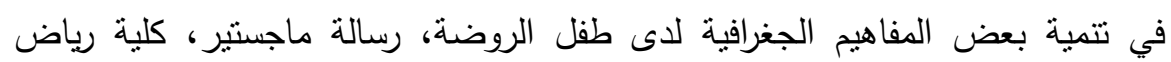
الأطفال، جامعة الإسكندرية. 


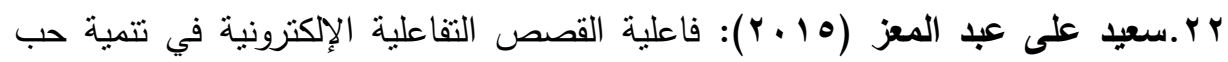

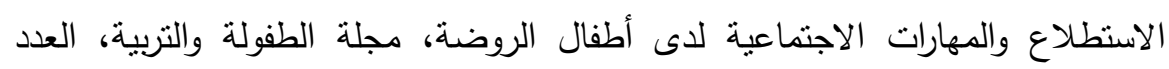

$$
\text { الحادي والعشرين، السنة السابعة. }
$$

r r.r.

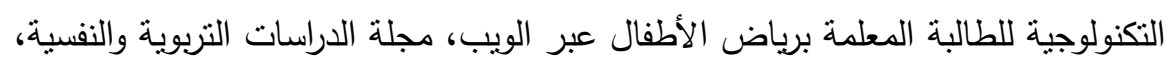

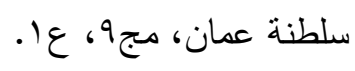

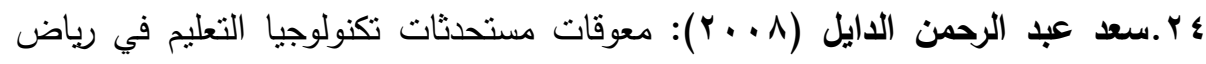
الأطفال بمدينة الرياض بالمملكة العربية السعودية, مؤتمر تكنولوجيا التعليم وتعليم الطفل العربي, جامعة القاهرة, معهد الدراسات والبحوث التزبوية.

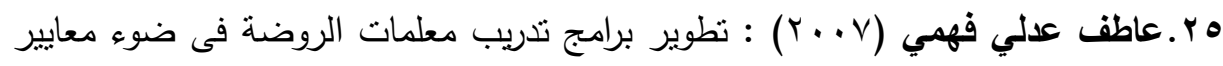

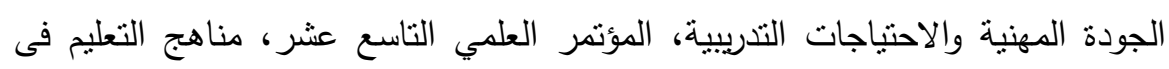
ضوء معايير الجودة من Or- بr يوليو المجلد الثالث.

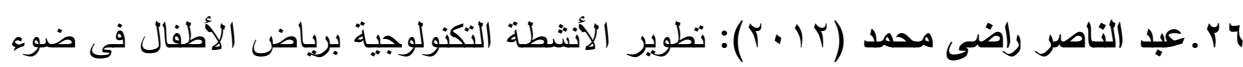

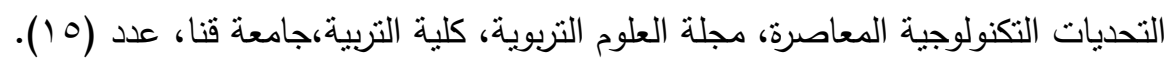

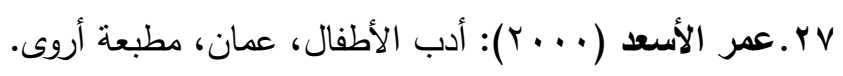

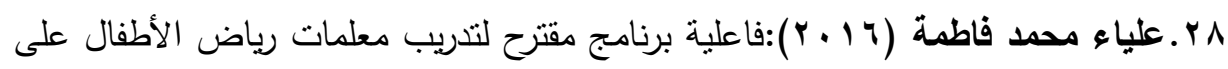

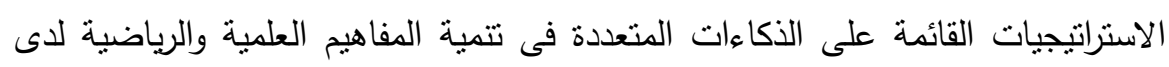

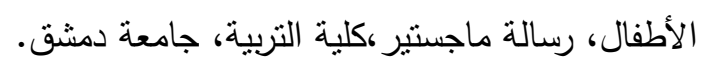

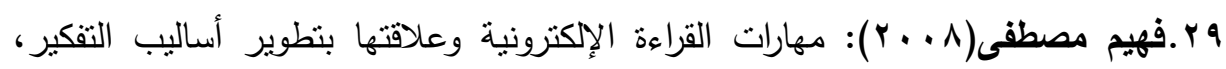
القاهرة، دار الفكر العربي.

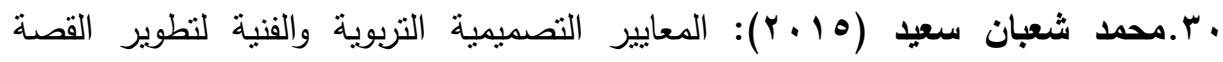

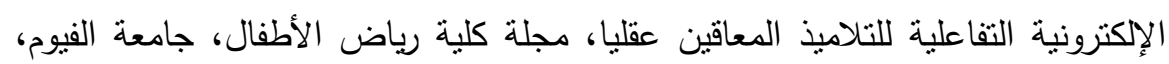

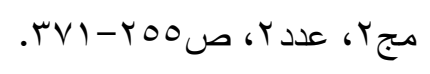

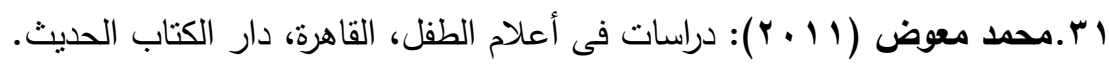




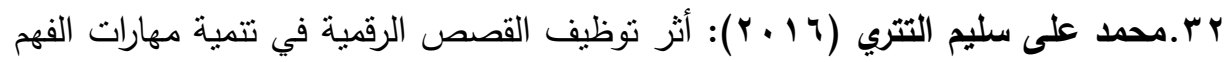

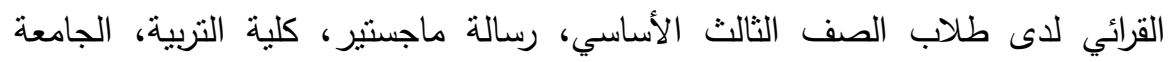

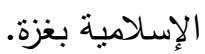

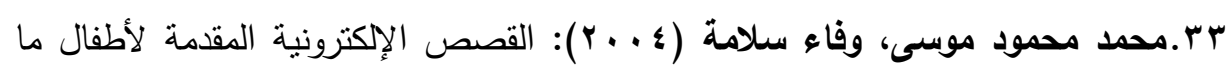

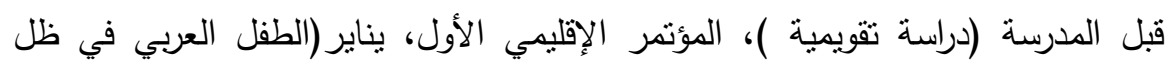

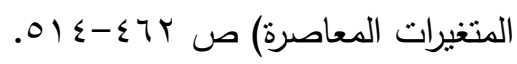

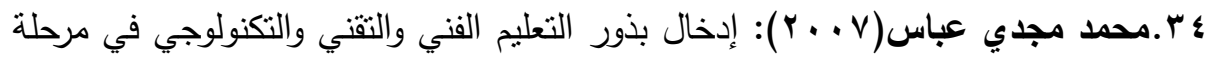

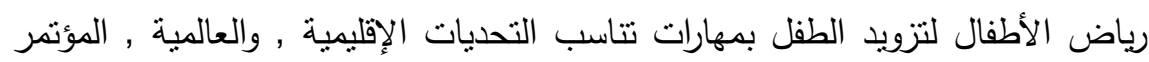

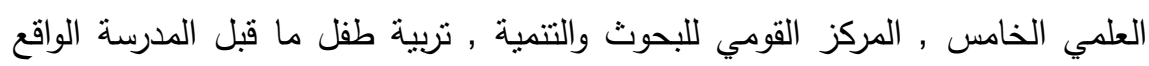
والطموحات, القاهرة.

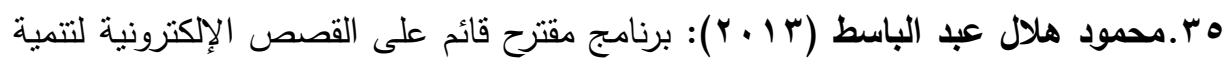

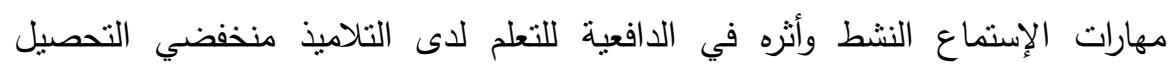

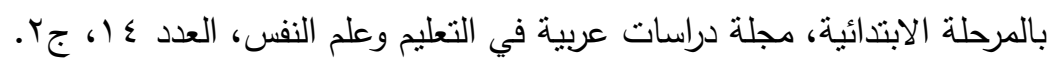

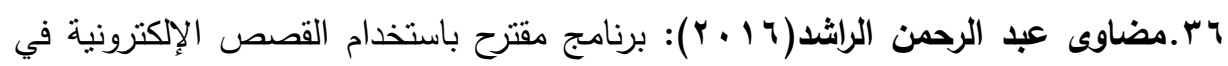

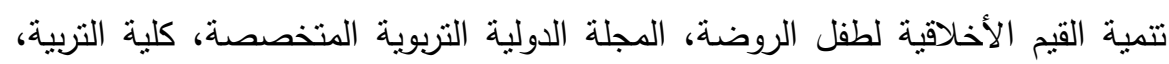
جامعة الأميرة نورة، مجلد (0)، عدد( الأ).

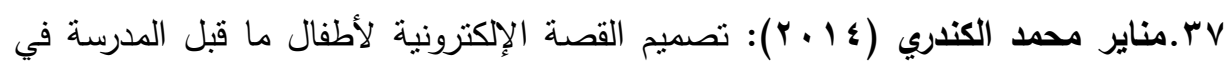

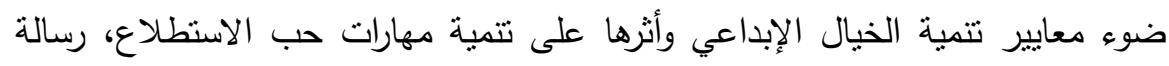
ماجستير ، جامعة الخليج العربي بالإمارات.

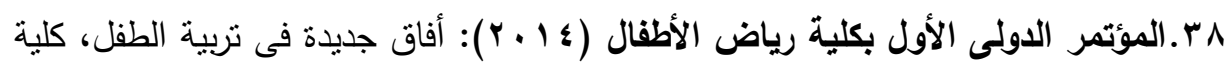

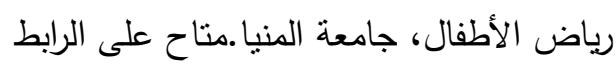

https://www.minia.edu.eg/kind/axes2.aspx q ب.الموتمر العلمى الثانى عشر للجمعية المصرية لتكنولوجيا التعليم بين تحديات الحاضر

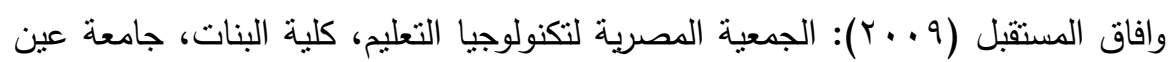
شمس.مناح على الرابط 
https://search.mandumah.com/Record/114985

• ـ.المؤتمر الدولى الأول (10 • ب): "التربية افاق مستقبلية، كلية التربية، جامعة

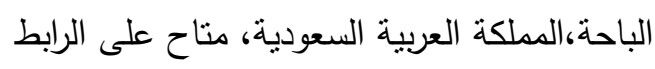

https://portal.bu.edu.sa/conferences/-

/journal_content/56_INSTANCE.../43852363

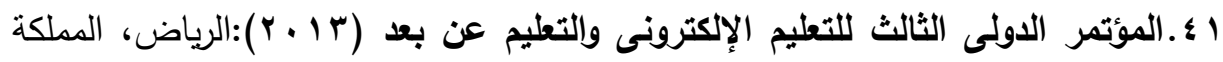

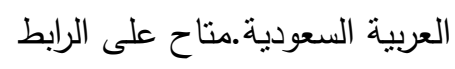

https://eli.edu.sa/2013/sities/default/files/ abstract/ rp252.pdf

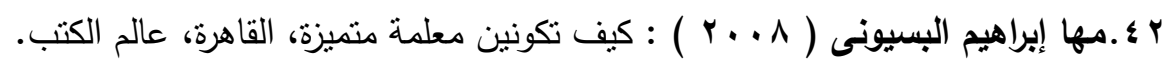

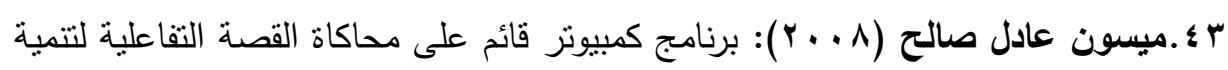
بعض القيم الأخلاقية لأطفال ما قبل المدرسة، رسالة ماجستير غير منشورة، كلية التربية، جامعة المنصورة.

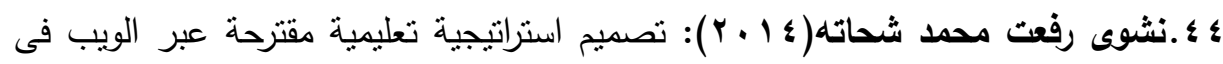

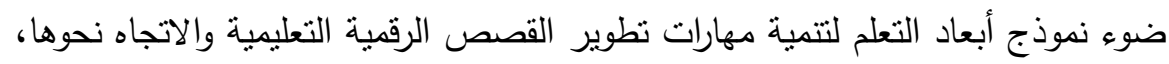

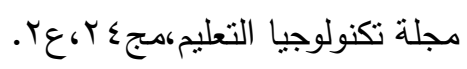

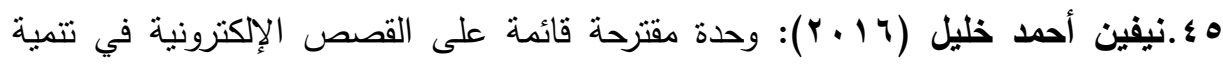

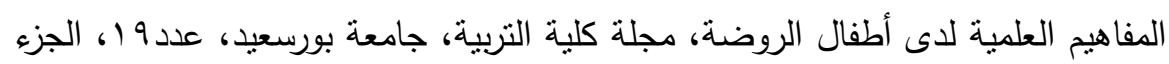

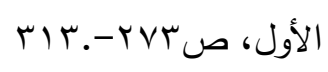

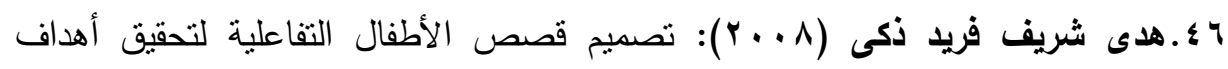

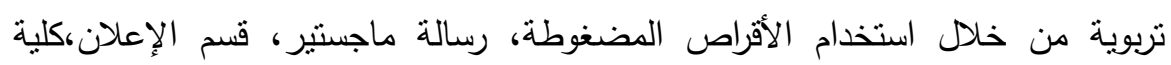
الفنون النطبيقية، جامعة حلوان.

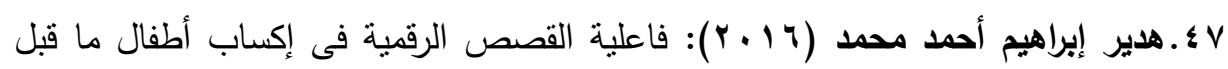
المدرسة بعض المفاهيم التاريخية، رسالة ماجستير، كلية رياض الأطفال، جامعة المنيا. 


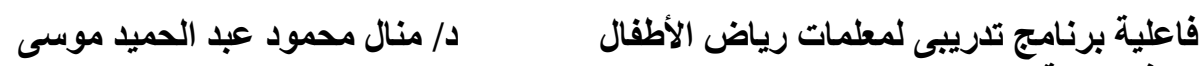

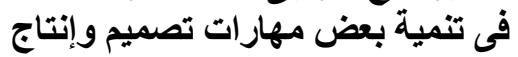

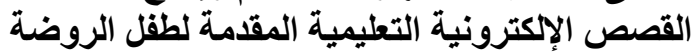

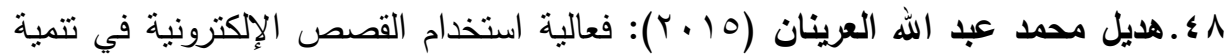

بعض المهارات اللغوية لاى طفل الروضة، رسالة ماجستير، كلية التربية، جامعة أم

القرى.

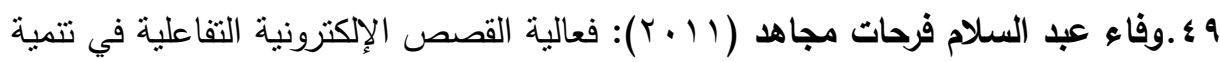

الوعي السياسي لدى أطفال الحلقة الأولى من التعليم الأساسي، معهد الدراسات والبحوث

التربوبة، جامعة القاهرة.

•. وفاء عبد الله محسن (T 1 • r): تحليل محتوى تطبيقات قصص الأطفال المقدمة عبر

المتاجر الإكترونية الذكية والحواسيب اللوحية والكفية، مجلة الطفولة العربية، مجلد V)

$$
\text { العدد } 71 .
$$

\section{ثانيا: المراجع الأجنبية:}

51. Baratitsis ,T.Zianns. p( 2015):From Early Childhood to Special Education :Interactive Digital storytelling as a cooching Appriach for Fastering Social Empathy,procedia Computer Science, Volum(67),pages 231-240,ISSN,1877-050 Available at: Htt:/dx.doi.org/101016/j procs.2015,09,267.

52. Benmayor,R.(2008): Digital Storytelling as signature pedagogy for the new Humanities in Higher Education ,7-188.

53. Burch,M.,(2010): types of digital stories, university of Richmond writing centr, Availabl

Http: // writing2 .richmond. edu/writing/ wweb/ digitalstory/ digstorytypes .html.

54. Burkholder,P.,and Cross ,A.(2009): Video Klleld the Teqrm paper Star ?Tow Views, Academic Commons, Available at

http: //www.academiccommons.org/2009/01/video-killed-the -term -paper -star-two-views/

55. Buvala,S.(2009): How To Tell Astory Retrieved from: http://ezinearticles.com/?How -to-Tell-a-Story\&id=2133817.

56. Candreva,C,(2011): Digital storytelling in Kindergarten: Merging Literacy,Technology, and

Multimodality ,http//:udini.proquest.com/view/digital-storytelling-in pqid:2407413281/Retrieved in May 2013.

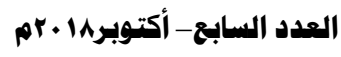


57. Coventry, M.(2006): Moving Beyond the Essay: Evaluatig Historical Analysis and Argument in Multimedia Presentations."journal of American History.

58. Chung ,S.(2008): Digital Storytelling in Integrated Arts Education.the International Journal of Arts Education, V.(4),N.(1), 33-50.

59. Campbell,A.(2012):Digital Storytelling in an Elementary Classroom Going Beyond Entertainment, procedia - Social and Behavioral Sciences ,69,385-393.doi Available:

htt:// dx.doi.org/10.1016/j,bspro.2012.11.432.

60. Clarke, R.\& Adam,A(2012): Digital storytelling in Australia Academic Prespectives and reflection, SAGE Arts and humanities in higer education Available

http://journals.sagepub.com /doi/full/10,1177/147022210374223.

61. Engle, A,.(2011): Everyone has Astiry to Tell: Digital storytelling. Retrieve From

http//tech2leam wikispaces.com/file/view/digital storytelling work _manual.pdf

62. Frazel.M.(2011): Digital Storytelling Guide For Educators. International Society for Technology in Education Washingtin.DC: Eugene. Oregon.

63. Hutchison , D(2012): The Student Filmmaker Enhancing Literacy :Skills through Digital Video production Research monograph (39) Available at

Htt//ww,edu.gov.on.ca/eng/literacynumeracy/inspire/research/ww_stud entllmak rs.pdf

64. Jakces,D.,\& Brennan,J(2015): Digital storytelling, Visual Literacy and 21 st century skills, the Learning Retrieved,from:

Http: // archive.techlearning.cim/techforum/Vaul Article Jakesbrennan.pdf.p6.

65. Kajder,S.et.al.(2005): D Digital storytelling and digital video Learning\& leading with Technology ,(32) 5,40-43. 

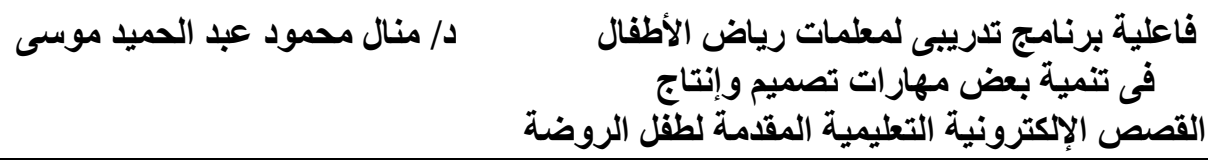

66. Kordaki ,M.(2013): on the design of edycational digital stories : the Ed.w model in proceedings of th world conference on Educational Sciences ,05-8 February 2013.Sapienza University if Rome,Italy proceedia -Social and Behavioral Science, Volum (116) ,Pages 16311635.

67. Lambert.J.(2010): Digital storytelling, cookbook the Center for Digital Storytelling, a non-profil arts and education organization: Digital Diner Press.9-19.

68. Lanir.L.(2012):what is Digital storytelling ?High Tech Education Aids from http://www.Decodedscince.com/ outh or /leslev- lanir.

69. Miller,E.,(2009) : Digital Storytelling ,A Graduate Review, University of northern iowa, http: //www. Uni.edu/icss/researchhelps/miller.pdf.

70. Norman.A(2011): Digital Storytelling In Second Language Learning.Master.s Thesis In Didactics Fir English and Foreign Languages. Norwegian University for Science and Technology: Norway.

71. Ohler.J(2008): Digital Storytelling in Classroom :New Media Pathways to Literacy Learning.and Creativity.Thousand Oaks CA : Cowin Press.

72. Robin,B.R.(2008): The effective uses of digital storytelling as a teaching and learning tool.In Flood ,j.,Heath ,S.B.,\&Lapp,D.(Eds),Hand book of research on teaching Literacy tgrough communicative visual arts (pp429-440).new York: Lawrence. Erlbaum.

73. Robin,B. (2011):.Digital storytelling : Hnds-ons Lab:The Educational Uses if Digital, storytelling,Austin,TX.

74. Roland,C(2006): Digital Stories in the Classroom "school Art,Vol,7 Issue

75. Sadik Alaa.(2008) :Digital Storytelling: Meaningful Technology Integrated Approach for Engaged Student Learning Association for Educational Communications and Technology , vol,56 , pp.506-489 ,Retrieved from:

Http: //classroom web20.pbwirks.com/f/digital storytelling.pdf.

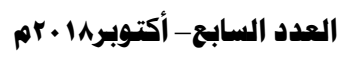


76. Rahimi, M., \& Yadollahi, S. (2017). Effects of offline vs. online digital storytelling on the development of EFL learners' literacy skills. Cogent Education, 4(1), 1285531.

77. Spicer ,S.(2013) : The Relationship Between Digital Storytelling Creation and Self -Efficacy Beliefs on Media Production Skill sets in First Year College Student.minnesota,published by proquest LLC.Available at http://conservancy,umu.edu/handle/11299/162873.

78. Valencia,Spain(2012): The Educational Uses if Digital Storytelling The International Conference on Digital Storytelling. The University of Houston. 